Claremont Colleges

Scholarship@ Claremont

2013

\title{
Academic Support Experiences and Perceptions of Postsecondary Students with Disabilities: A Public and Private University Comparision
}

Heather T. Wizikowski

Claremont Graduate University

\section{Recommended Citation}

Wizikowski, Heather T., "Academic Support Experiences and Perceptions of Postsecondary Students with Disabilities: A Public and Private University Comparision" (2013). CGU Theses \& Dissertations. Paper 76.

http://scholarship.claremont.edu/cgu_etd/76

DOI: $10.5642 / \operatorname{cguetd} / 76$

This Open Access Dissertation is brought to you for free and open access by the CGU Student Scholarship at Scholarship @ Claremont. It has been accepted for inclusion in CGU Theses \& Dissertations by an authorized administrator of Scholarship @ Claremont. For more information, please contact scholarship@cuc.claremont.edu. 
Academic Support Experiences and Perceptions of Postsecondary Students with Disabilities:

A Public and Private University Comparison

by

Heather Taylor Wizikowski

A final project submitted to the Faculty of Claremont Graduate University in partial fulfillment of the requirements for the degree of Doctor of Philosophy in Special Education.

Claremont Graduate University

2013

(C) Copyright Heather Taylor Wizikowski, 2013

All rights reserved. 


\section{APPROVAL OF THE REVIEW COMMITTEE}

This dissertation has been duly read, reviewed, and critiqued by the Committee listed below, which hereby approves the manuscript of Heather Taylor Wizikowski as fulfilling the scope and quality requirements for meriting the degree of Doctor of Philosophy in Special Education.

Deborah Deutsch Smith, Chair

Claremont Graduate University

Professor

Sue Mortorff Robb

Claremont Graduate University

Professor

Scott Thomas

Claremont Graduate University

Dean

Bianca Montrosse Moorhead

Western Carolina University

Assistant Professor 


\begin{abstract}
Academic Support Experiences and Perceptions of Postsecondary Students with Disabilities:

A Public and Private University Comparison

by

Heather Taylor Wizikowski

Claremont Graduate University: 2013

Legislation, social awareness, and advancements in medicine and assistive technology have created meaningful postsecondary opportunities for students with disabilities over the past 30 years. Mainstreaming, inclusion, and transition planning in elementary and secondary schools also greatly contributed to the increased achievement of students with disabilities. Today, $15 \%$ of students with disabilities attend four-year colleges. Current federal data show $88 \%$ of private and $99 \%$ of public universities report students with disabilities enrolled at their institutions. Much of the current research focuses on institutional practice and need. There is a gap in the research when looking at student needs and experiences.

This quantitative dissertation study analyzed the relationships between student perceptions, self-advocacy awareness and confidence levels, and available disability accommodations at two institutions of higher learning, one public and one private. One hundred and thirteen undergraduate students with disabilities completed an online survey. Thirty-four respondents attend the private university, and 79 respondents attend the public university. Descriptive and associative statistics were analyzed for comparative experiences between the two settings, knowledge and confidence of self-advocacy skills, and relationships between these variables and disclosure patterns.
\end{abstract}


The sample population of undergraduate students with disabilities appears to have similar experiences. In both settings, public and private, students have similar identification patterns, accommodation experiences, and support experiences. Students in both settings are satisfied with their academic support office and staff. The accommodations students find useful are alternative exam formats, documentation sent to faculty, and registration assistance. Students report having an awareness of and confidence using self-advocacy skills, but have had little to no training in these skills. Students report weak understanding of their legal rights, disability, and accommodations. Students also report poor transition experiences from secondary to postsecondary education, a finding that matches current research.

Transition planning at the secondary level must be purposeful in preparing students for four-year college settings when appropriate. Students need self-advocacy skills and disability awareness training before transitioning to postsecondary settings. Future research should also include revisiting the usefulness of accommodations offered in postsecondary settings, studying effective transition models, and looking at the relationship between self-advocacy confidence levels and postsecondary retention rates. 


\section{Dedication}

To my girls, Paloma and Vivian, may you always grow in love and strength. 


\section{Acknowledgements}

I would like to first acknowledge my dissertation committee. I appreciate your individual strengths and talents and how they have been integral to my own growth as an academic. Thank you Deb, for teaching me about being strong in my beliefs and in being meticulous in my work. Thank you also for the immeasurable opportunity I received during my time at IRIS. Thank you, Sue, for always having a kind ear and reminding me about the importance of balance. Thank you, Scott, for saving the day when I suddenly needed a new committee member and doing so with such enthusiasm and engaging commentary. Bianca, I will be eternally grateful for your patience and guidance through statistical analysis, you truly have a gift.

I would like to acknowledge my wonderful family. Mom and Dad, thank you for instilling in me a love of learning and for teaching me that I should better myself through education for the benefit of the greater good. Thank you also for the priceless and selfless gift of being there whenever your granddaughters or I need you. You made all this possible in so many, many ways. To my sister, Tori, even though the miles separate us, you are always there when I needed to talk something through and I couldn't be more grateful.

To my husband, Paul, I appreciate all the sacrifices you have made to get me to this point. Thank you for being both flexible and strong in the right doses, just when I needed each. Paloma and Vivian, you have made so many small sacrifices because of my work. I hope that through the sacrifice I have asked of you, I have taught you a bit about reaching for the stars and being your own women. 
Thank you to my IRIS family. Jackie and Jen, you became such wonderful friends and such an amazing support system for me at a time when I really needed it. Thank you, Michael, for being so understanding through this process.

I would also like to acknowledge Dawn Hunter. Thank you for believing in my potential long before I could see it. You are a wonderfully compassionate academic whom I have learned so much from over the years.

Thank you also to all the men and women who helped make this study possible. Thank you to the disability offices at both colleges for being so supportive of my research. And a huge thank you to the students who participated in the survey. I only hope that I did your responses justice. 


\section{Table of Contents}

Chapter One: Statement of the Problem .......................................... 12

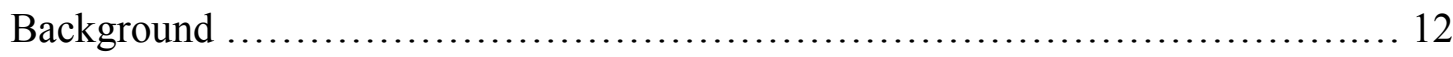

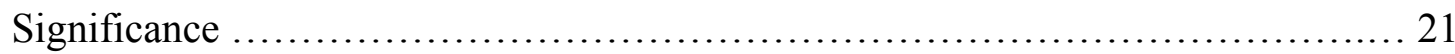

Research Questions .................................................... 22

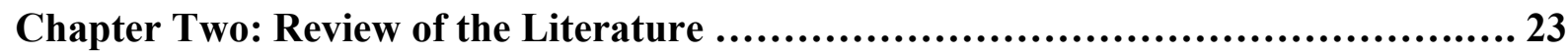

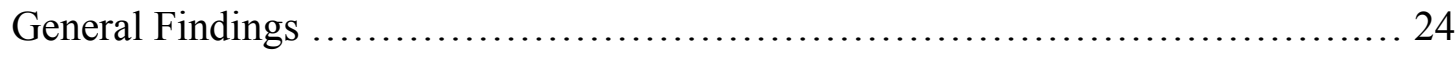

Impact of IDEA and Other Legislation on Postsecondary Education .............. 25

Campus Climate: Faculty, Disability Support Services, and Professional Development

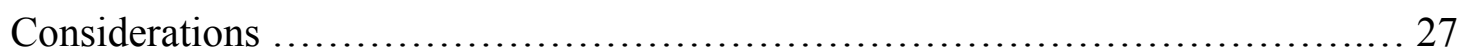

Accommodations and Services at the Four-Year Postsecondary Level .............. 33

Self-Advocacy: Necessary Skills and Adolescent Development Considerations ...... 37

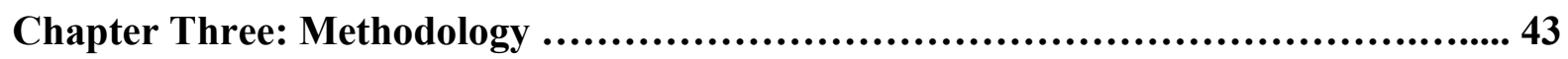

Research Design...................................................... 43

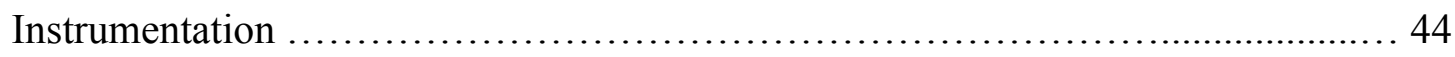

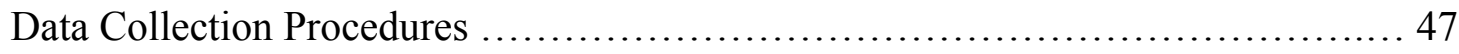

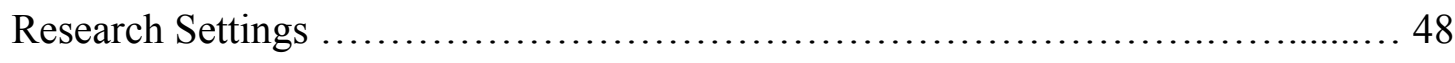

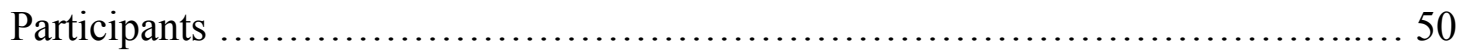

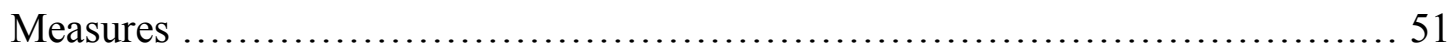

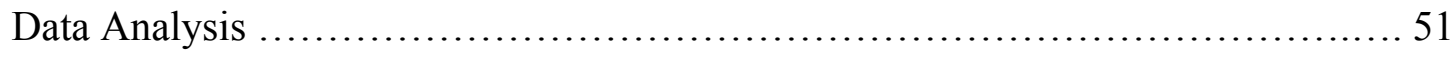

Chapter Four: Results ............................................................ 53

Research Questions ................................................. 53

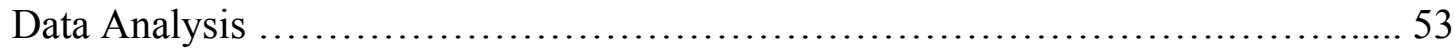


Chapter Five: Background, Discussion, and Recommendations

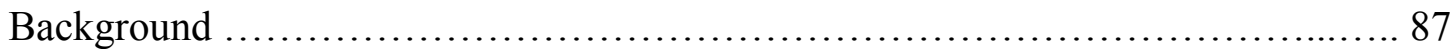

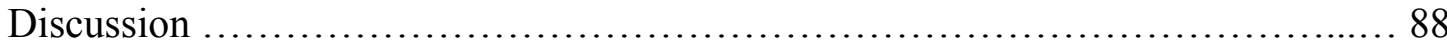

Limitations .............................................................. 97

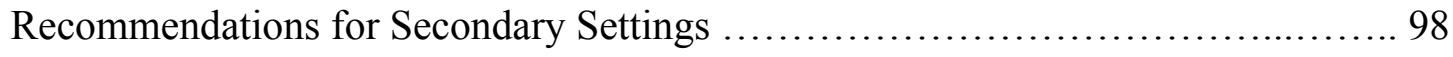

Recommendations for Postsecondary Settings ............................. 99

Recommendations for Future Research .................................... 100

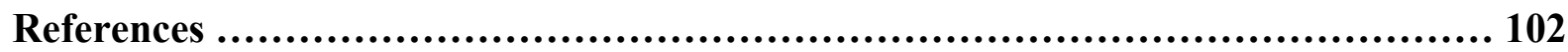

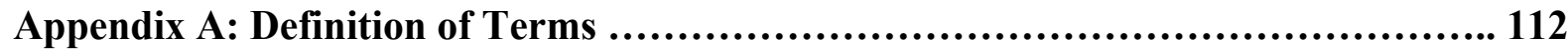

Appendix B: AHEAD Disability Support Program Standards and Performance

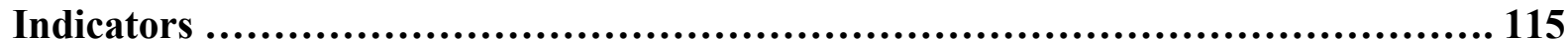

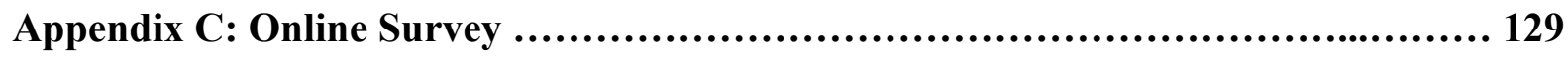

Appendix D: Participant Recruitment Email ....................................... 149 


\section{List of Tables}

Table 1. Percentage of Disabilities Reported by Four-year Degree Granting Postsecondary Institutions that Enrolled Students with Disabilities, by Disability Category and

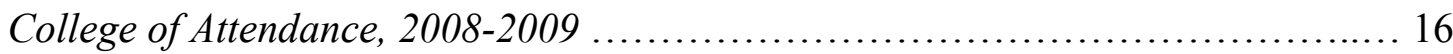

Table 2. Percentage of Four-year Degree Granting Institutions Enrolling Students with Disabilities That Provided Various Services or Accommodations to Students with Disabilities, by College of Attendance, 2008-2009

Table 3. Undergraduate Student Population Characteristics from Sampled Universities;

2011

Table 4. Descriptive Analyses of Demographic Characteristics of Undergraduate

Respondents 55

Table 5. Descriptive Analyses of Reported Disability Categories by College of

Attendance 56

Table 6. Descriptive Analyses of Current Major by College of Attendance 56

Table 7. Descriptive and Associative Analyses of Whom Students Have Identified to at Their College by College of Attendance 58

Table 8. Descriptive Analyses of Precipitating Event That Led Students to Identify to Their College by College of Attendance 59

Table 9. Descriptive Analyses of When Student Chose to Identify to Their College by College

of Attendance 60

Table 10. Descriptive and Associative Analyses of Accommodation Services Students Have

Used by College of Attendance 
Table 11. Descriptive and Associative Analyses of Student Perceived Usefulness of Accommodations

64

Table 12. Descriptive and Associative Analysis of Student Satisfaction with Academic Support Office by College of Attendance 67

Table 13. Descriptive Analyses of Student Reported Services Currently Offered Through the Academic Support Office at Their College; Services Students Would Like to See Offered 68

Table 14. Associative Analyses of Student Reported Services Currently Offered Through the Academic Support Office at Their College; Services Students Would Like to See Offered

Table 15. Descriptive Analyses of Past Legal and Transition Education 77

Table 16. Descriptive and Associative Analyses of Student Awareness of Self-Advocacy Skills Rating and Whom Students Have Identified to at Their College 85

Table 17. Descriptive and Associative Analyses of Student Confidence Using Self-Advocacy Skills Rating and Whom Students Have Identified to at Their College 86 


\section{Chapter One: Statement of the Problem}

\section{Background of Problem ${ }^{1}$}

Civil rights legislation and social equity awareness, as well as advancements in assistive and informational technology, education and medicine have resulted in better outcomes for students with disabilities. The implementation of mainstreaming in elementary and secondary schools, placement in the least restrictive learning environment, and inclusion along with formal transition planning have helped foster greater high school completion rates and expectations for postsecondary education for students with disabilities (Brinckerhoff, McGuire, \& Shaw, 2002). More than $60 \%$ of students receiving special education services spend more than $80 \%$ of their school day in general education classrooms (United States Department of Education [USDOE], 2012). Increases in reading proficiency, more students with disabilities graduating with a high school diploma, and decreases in dropouts rates also account for increased opportunities for postsecondary enrollment for students with disabilities (USDOE, 2010).

These positive outcomes create opportunities for better preparation for college and greater numbers of students with disabilities pursuing higher education (Burgstahler \& Moore, 2009). Approximately 15\% of all students with disabilities pursued four-year postsecondary education in 2010 , compared to $37 \%$ of their typical peers (Sanford, et al., 2011). This percentage is up from $15 \%$ of students with disabilities pursuing any postsecondary education in 1987 (vocational or career training, two-year college, and fouryear college combined) (USDOE, 2010). The American with Disabilities Act (ADA) in 1990, along with the reauthorized Individuals with Disabilities Education Act (IDEA) Amendments

\footnotetext{
${ }^{1}$ See Appendix A for a complete list of terms.
} 
of 1997, increased the accessibility of postsecondary education for many students with disabilities (Crank \& Deshler, 2001; National Center for the Study of Postsecondary Educational Supports [NCSPES], 2005). Within two decades, the percentage of full-time college freshmen with disabilities increased from 2.3\% in 1978 to $9.8 \%$ in 1998 (Council for Learning Disabilities [CLD], n.d.). Current federal data place the number attending college at 11\% (United States Government Accountability Office [GAO], 2009). Ninety-eight percent of four-year colleges in 2003 reported having at least one student with a disability (Johnson, Zascavage, \& Gerber, 2008). Current federal data show $88 \%$ of private universities and $99 \%$ of public universities report students with verified disabilities enrolled at their institutions (Raue \& Lewis, 2011). While the increase in the numbers of students with disabilities enrolling in postsecondary education is encouraging, the graduation rates are not (Shepler \& Woosley, 2012). Federal data show that $29 \%$ of students with disabilities who enroll in fouryear colleges receive a degree compared with $42 \%$ of their typical peers (Sanford, et al., 2011).

\section{Postsecondary Response}

Institutes of higher learning have responded to the improved enrollment of this student subgroup. In 1977, 233 colleges reported the existence of disability support offices. That number increased to 1,333 by 1999 (Brinckerhoff, McGuire, \& Shaw, 2002). In 1977, the Association on Higher Education and Disability (AHEAD) was founded and reported 32 members. In 2012, the AHEAD website reported their membership had grown to 2,500 international college faculty and personnel.

Several key events helped shape the modern practices of supporting students with disabilities in postsecondary settings. In 1988, the National Joint Committee for Learning 
Disabilities proposed and adopted changes in the definition of learning disabilities. The focus became learning disabilities as a lifespan issue, which highlighted need for disability supports past secondary school (Skinner, 2004). This change was followed by legislation that may have led to an increase in the number of students with disabilities enrolling in postsecondary settings. In order to better support students with disabilities, the Higher Education Opportunity Act (HEOA) of 2008 added new provisions to the Higher Education Act (HEA) of 1965. The HEOA added new provisions to the HEA to increase access, persistence, and completion rates of students with disabilities though improving transition practices, creating more accessible instructional materials, and disseminating best practice guidelines (Mamiseishvili \& Koch, 2011). The Americans with Disabilities Amendments Act of 2008 amended ADA of 1990 to provide broader coverage, and the Post-9/11 Veterans Educational Assistance Act of 2008 (Post-9/11 GI Bill) expanded educational benefits for veterans, many of who seek postsecondary education after acquiring disabilities during their military service (GAO, 2009). It is anticipated that up to 2 million veterans will enroll in postsecondary institutions and as many as $25 \%$ of these veterans will have hidden disabilities such as Traumatic Brain Injury (TBI) or Post Traumatic Stress Disorder (PTSD). In addition, many more will have physical disabilities and sensory impairments (Mamiseishvili \& Koch, 2011).

\section{Federal Response}

Poor graduation numbers were the impetus for federal funding of demonstration projects to improve the quality and outcomes of postsecondary students with disabilities. In 1991, 21 colleges were awarded demonstration project grants that focused on postsecondary students with disabilities. In 2008, this number had increased slightly to 23 universities being awarded demonstration project grants to ensure students with disabilities receive a quality 
higher education (USDOE, 2011). The Amendments to the HEA of 1998 provided millions of dollars for professional development and technical assistance for faculty and administrators to ensure students with disabilities receive a quality postsecondary education. Total funding of these projects was $\$ 5,000,000$ in 2000 and $\$ 6,600,000$ in 2008 (USDOE, 2011).

\section{Student Characteristics}

Students with disabilities mirror their peers without disabilities in terms of gender, race, and more recently, age. In 2000, postsecondary students with disabilities were on average four years older than their typical peers. In 2008, this average decreased to only one year older than their peers without disabilities. Another change during this time was that students with disabilities were entering postsecondary settings sooner after graduating high school than in years past (GAO, 2009). Federal data document that students with disabilities are more likely to attend community colleges or vocational programs rather than four-year colleges (GAO, 2009; Sanford, et al., 2011). Sixty-eight percent of students with disabilities attend two-year colleges or vocational schools compared with 15\% attending four-year colleges (Sanford, et al., 2011). Federal data reporting disability types by school of attendance are detailed in Table 1.

This section intentionally left blank 


\section{Table 1}

Percentage of Disabilities Reported by Four-year Degree Granting Postsecondary Institutions that Enrolled Students with Disabilities, by Disability Category and College of Attendance, 2008-2009

\section{College of Attendance}

Disability Category

$\underline{\text { Public } \%} \quad \underline{\text { Private } \%}$

\begin{tabular}{lrr}
\hline Specific Learning Disability & 26.0 & 36.0 \\
ADD/ADHD & 23.0 & 26.0 \\
Emotional Disturbance & 16.0 & 13.0 \\
Other Health Impairment & 11.0 & 11.0 \\
Orthopedic Impairment & 7.0 & 3.0 \\
Difficulty Hearing & 3.0 & 3.0 \\
Difficulty Seeing & 3.0 & 2.0 \\
Autism & 2.0 & 2.0 \\
Traumatic Brain Injury & 2.0 & 1.0 \\
Difficulty Speaking & 1.0 & 1.0 \\
Intellectual Disabilities & 1.0 & 1.0
\end{tabular}

Note. Adapted from "Students with Disabilities at Degree-Granting Postsecondary Institutions" by K. Raue and L. Lewis, 2011, National Center for Education Statistics, Postsecondary Education Quick Information System (PEQIS).

There are significant exclusions from the current literature on students with disabilities attending four-year colleges. Data gathered about students with disabilities only include students who have identified to their university disability support office. Federal longitudinal data only include students who received special education services in high school. This excludes data about students who are diagnosed in college and those who may not disclose to their school. By neglecting research about students who have chosen not to disclose their disability to their college, a large piece of the puzzle is missing that could help create meaningful postsecondary educational experiences for students with disabilities. Why do these students choose not to disclose? What events would cause them to disclose their 
disability to their college? How do retention rates correlate with disclosure patterns? Does age of diagnosis affect success rate in postsecondary settings?

\section{College Settings}

Another dimension not included in current literature is comparative, student-centered research between public and private university settings. While there is federally mandated institutional characteristic and enrollment reporting for schools that receive Title IV funding that can be disaggregated by school type, very little data about the experiences students with disabilities in these two settings are available. Is one setting likely to have better outcomes for students? The assumption would be that students at a private college may receive more individualized support, but federal data show that public universities have larger disability resource programs and therefore may be able to offer more comprehensive, and effective, support services (Raue \& Lewis, 2011). Another supposition regarding these two settings based on current research and federal data would be that private university faculty may be less inclined to accommodate students with disabilities as they see their college as highly selective and themselves impervious to changes in teaching methods (Brinckerhoff, McGuire, \& Shaw, 2002; Raue \& Lewis, 2011).

\section{Challenges}

Accommodations. Accommodations are guaranteed to students with verified disabilities under federal law. The manner in which these services are offered is up to each individual college. Colleges that receive Title IV funding are required to have at least one person on staff that coordinates accommodation services. Accommodation support ranges from one person who handles these needs in addition to other duties to an office with a full staff that assists students with disabilities with many academic and personal support services. 
Federal data show that a greater percentage of public universities offer a wider range of disability supports than their private counterparts (Raue \& Lewis, 2011). Most universities, public and private, have a similar standard list of accommodation services that are offered to students. Table 2 details accommodation frequencies at four-year colleges.

\section{Table 2}

Percentage of Four-year Degree Granting Institutions Enrolling Students with Disabilities That Provided Various Services or Accommodations to Students with Disabilities, by College of Attendance, 2008-2009

\section{College of Attendance}

Accommodation

Public $\% \quad$ Private $\%$

\begin{tabular}{lrr}
\hline Sign Language Interpretation & 69.0 & 29.0 \\
Captioning & 43.0 & 15.0 \\
Oral Interpreters & 28.0 & 12.0 \\
Readers & 79.0 & 51.0 \\
Note Takers & 92.0 & 74.0 \\
Faculty-provided Notes & 79.0 & 67.0 \\
Adaptive Technology & 87.0 & 62.0 \\
Room Arrangements & 74.0 & 49.0 \\
Paratransit & 30.0 & 13.0 \\
Personal Attendants & 4.0 & 8.0 \\
Adapted Texts & 88.0 & 61.0 \\
Braille Materials & 73.0 & 41.0 \\
Learning Strategies or Study Skills & 50.0 & 57.7 \\
Tutoring & 89.0 & 67.0 \\
Course Substitution & 61.0 & 34.0 \\
Registration Assistance & 70.0 & 36.0 \\
Specific Career Services & 37.0 & 21.0 \\
Disability Benefits Counseling & 14.0 & 6.0 \\
Vocational Rehabilitation Counseling & 58.0 & 23.0 \\
Classroom Accessibility & 67.0 & 51.0 \\
\end{tabular}

Note. Adapted from "Students with Disabilities at Degree-Granting Postsecondary Institutions" by K. Raue and L. Lewis, 2011, National Center for Education Statistics, Postsecondary Education Quick Information System (PEQIS). 
There is also very little research on the effectiveness of postsecondary accommodation supports. Most support service offerings were created 30 years ago and were based on postsecondary students with physical disabilities who required physical access to the college campus. Today, the range of disabilities has changed a great deal on college campuses, as well as the technology available to students to help support their own learning. Modern students also expect an individualized selection of accommodations, not generalized accommodations from a menu of services, as was the practice in years past (Mellard \& Kurth, 2006). Do these students find current models of support effective? What are their own ideas of effective accommodations and supports? Such student-centered research is lacking in the current body of literature.

Controversies often surround students' accommodations at the college level. "In some cases, there is philosophical trepidation pertaining to the use of accommodations in postsecondary classrooms which centers on concerns that providing accommodations for students with disabilities inherently threatens the fairness of the college academic experience" (Lindstrom \& Tuckwiller, 2008, p. 95). Some postsecondary professionals stand by the argument that "a college education is for the brighter students in society, with learning disabilities being perceived (incorrectly) as a lack of intellect and/or an excuse for avoiding more rigorous courses such as languages or mathematics” (Crank \& Deshler, 2001, p. 218).

Professional Development. Bringing the issue of students with disabilities to the attention of postsecondary administration and faculty increases the likelihood that students with disabilities will find their needs accommodated more willingly by faculty and staff. There is currently little training that was found in the literature to aid faculty members in assisting students with disabilities succeed in their classes. The training programs and 
resources that were located were all voluntary programs. Faculty often have preconceived negative notions about "hidden" disabilities such as learning disabilities and attention deficit disorders and are less likely to accommodate these students than they would students with visible disabilities, such as students in wheelchairs or with physical disabilities (Brinckerhoff, McGuire, \& Shaw, 2002; Getzel, 2008).

Self-advocacy. Students with disabilities face challenges from within, as well as from the postsecondary settings they join. Students with disabilities oftentimes perceive themselves as unprepared for the increased rigor of postsecondary education. This can lead to anxiety and difficulties with academic expectations which can all lead to decreased retention rates (Reed, et al., 2009; Connor, 2012). Self-advocacy skills training would address this issue. Selfadvocacy includes having a concept of purpose, thorough goal setting, plan development, being able to articulate personal learning needs, and persistence despite challenges. These concepts are crucial for students with disabilities if they are to succeed in postsecondary education (Mamiesishvili \& Koch, 2011). Self-advocacy skills need to be explicitly taught to students, preferably at a young age. Too often, students with disabilities are supported using a dependency model in elementary and high school and don't develop the skills to advocate for

their own learning needs (Brinckerhoff, McGuire, \& Shaw, 2002). Then students transition to college where Section 504 and ADA require students to advocate for their own needs.

\section{Post-school Outcomes}

There are distinct reasons why successful postsecondary education is so crucial for students with disabilities. The possible benefits from postsecondary education include increased earnings (Carnevale and Desrochers, 2003), improved health (Ross and Mirowsky, 2011), and increased job satisfaction (Wolniak and Pascarella, 2005). As the American 
economy becomes increasingly knowledge based, attaining a postsecondary education has become more critical (Carnevale and Desrochers, 2003). To compete in the current and future labor markets, people with disabilities need to attain four-year degrees (O'Neill, Markward, \& French, 2012). There is a 50.4\% labor force participation rate for people with disabilities who have completed at least four years of college. This is a greater correlation than that of the general population (NCSPES, 2005). Those with disabilities with less than four years at a four-year college are employed at double the rate of those with just a high school diploma (NCSPES, 2005). This demonstrates how powerful postsecondary access can be on life outcomes and why additional research is so important.

\section{Significance of Study}

This dissertation study is student-centered, which departs from much of the current research that focuses on institutional practice and need. It has the goal of delving deeper into the self-advocacy awareness and confidence levels of four-year college students with disabilities. Through the course of this study, student perceptions of the support they receive at school becomes a significant variable relating to accommodations and self-advocacy as well as the level of knowledge that students have regarding ADA and IDEA.

There are several theoretical and practical implications to undertaking this study. This research could lead to further academic study on confidence levels of students with disabilities in terms of retention and success rates in college. Factors that lead to success could be studied more closely in postsecondary settings. Practically, the data gained in this dissertation study could potentially be used as a starting point by a disability services office to review and reassess their current services offered to students with disabilities. Such a review could aid in the development of professional development opportunities for faculty and staff 
that do, or may at some time, work with a student with a disability. This study is intended to connect to earlier studies in looking at how the landscape of postsecondary education has, or has not, changed for students with disabilities. This research will attempt to provide an understanding of today's students with disabilities need different services and supports than students in years past.

\section{Research Questions}

Four research questions guided this study:

1. What are the comparative experiences with academic supports of four-year undergraduate students with disabilities at a private and a public postsecondary setting?

2. What do postsecondary students with disabilities know about self-advocacy skills?

3. How confident are postsecondary students with disabilities using self-advocacy skills?

4. How do self-advocacy awareness and confidence levels influence disclosure patterns for college students with disabilities? 


\section{Chapter Two: Review of the Literature}

As more students with disabilities enroll in postsecondary education, more research is being devoted to the needs and experiences of these students. Articles written before 1990 and the passage of the American with Disabilities Act (ADA) were generally written about twoyear, vocational college settings. Between 1986-1989, articles written about four-year college settings usually detailed future institutional planning for potential students with disabilities. It wasn't until the very beginning of the last decade that students with disabilities attending four-year colleges became an emerging topic in the postsecondary education research literature.

A review of current literature was conducted and focused on students in four-year postsecondary settings. ERIC, PsycINFO, Academic Search Premier, and ProQuest (PQDT) database searches were completed to locate literature relating to the following keywords: postsecondary, academic, support, students, disabilities, learning, faculty, services, persistence, college, university, graduation, employment outcomes, accommodations, determination, adolescent development, and self-advocacy. Results from 2000 to the present were selected. From these keywords and within the years chosen, 91 articles and dissertations were found that matched three or more keywords. Of these resources, 63 matched the search goals of the literature review that were: transition, student achievement and retention, employment outcomes, student advocacy, accommodation patterns, and disclosure patterns. Several articles prior to 2000 were then reviewed and included to address changes over time. The themes that emerged in the literature included: the effects of the Individuals with Disabilities Education Act (IDEA) and legal decisions on postsecondary enrollment of students with disabilities; campus climate, especially in regards to faculty, disability support 
services and professional development; accommodations and services; and student selfadvocacy. Disability documentation was another theme present in much of the literature on postsecondary education for students with disabilities. However, due to the complex nature of documentation at the postsecondary level, the controversy surrounding documentation for different types of disabilities, inconsistency in documentation policies, and the fact that this study does not focus on documentation at the postsecondary level, this theme was excluded from the literature review.

\section{General Findings}

There has been steady growth in the number of students with disabilities enrolling in postsecondary institutions over the past three decades. In 1978, 3\% of students enrolled in college reported having a disability. Today, students with disabilities account for what is believed to be $11 \%$ of all students enrolled in postsecondary education that includes two-year, four-year, vocational, and certificate programs (Government Accountability Office [GAO], 2009). In the literature reviewed, the percentage of students with disabilities ranged from $10 \%$ to $40 \%$ of all students if part-time students and students who had not self-identified were included (Lindstrom \& Tuckwiller, 2008). However, this increased enrollment is only the first hurdle for students with disabilities. "Amid this changing postsecondary environment, students with disabilities frequently feel overwhelmed, resulting in low retention and graduation rates" (National Center on Secondary Education and Transition [NCSET], 2004, p. 1). Sitlington and Frank (1990) found that one year after leaving high school, only $6.5 \%$ of students with disabilities who had enrolled in postsecondary settings had persisted.

Disclosure patterns and persistence rates were interconnected in the research literature. Most literature estimated the rate of student self-disclosure on college campuses at only one in 
four (Burgstahler \& Moore, 2009). This was the accepted rate of disclosure included in many articles; however, no studies were found to substantiate this rate. Research does show, however, that most students who do choose to self-disclose do so as a reactive measure rather than a proactive one (Brinckerhoff, McGuire, \& Shaw, 2002). Students with disabilities also don't persist at the same rates as students without disabilities, take longer to graduate than their peers, and leave school for periods of time more often (Wessel, Jones, Markle, \& Westfall, 2009). In a 1996 study by Berkner, Curraro-Alamin, McCormick, and Bobbit, 54\% of students with disabilities had persisted while $64 \%$ of their typical counterparts had graduated or continued to be enrolled.

\section{The Impact of IDEA and Other Legislation on Postsecondary Education}

Current researchers agreed overwhelmingly that the passage of three key pieces of legislation in the past 40 years, foremost the passage of IDEA, forever positively changed the educational outcomes of students with disabilities. With increased participation of special education students in general education classes, as well as increased rigor in all high school classes, more students with disabilities are being admitted to postsecondary settings. Because of increased enrollment and success in postsecondary settings in the last two decades, students with disabilities have made significant progress in academia (Council for Learning Disabilities [CLD], n.d.).

Section 504 of the Rehabilitation Act of 1973 was the first federal civil rights legislation designed to protect the rights of people with disabilities as well as the third important piece of legislation to advance the educational progress of students. Enforcement of Section 504 falls under the jurisdiction of the Office for Civil Rights (OCR) within the United States Department of Education (USDOE). It refers only to non-discrimination; it is not a 
funding statute. Any school that receives federal funds is obligated to follow the mandates of accessibility included in this act (PACER Center, 2003). Eligibility for protection under Section 504 is determined by the following criteria:

1. If the person:

a. has a physical or cognitive impairment that substantially limits one or more life functions;

b. has a history of such an impairment; or

c. is regarded as having such a impairment; and

2. If the person with a disability meets the academic and technical standards requisite to admission or participation in a college or university's programs or activities, then that student must be ensured equal educational opportunity, not a free, appropriate education as in IDEA.

Under P.L. 94-142 (1975), later renamed IDEA, all children with disabilities between the ages of 3 and 21 are guaranteed a free, appropriate public education (FAPE) in their least restrictive environment. This is supported by the use of federal funds according to a payment formula that takes into account the national average expenditure per child attending school and the number of students with disabilities receiving special education in each state. Under this law, two criteria must be met to establish eligibility for services: (1) a student must have at least one of the disabilities defined in the law, and (2) the student requires special education and/or related services (IDEA, 2004).

IDEA assures elementary and secondary education services to children with disabilities in the United States. The act is very precise in its regulations and has little room for interpretation. The act governs how states and public agencies provide early intervention, 
special education, as well as related services to eligible infants, toddlers, children, and youth with disabilities. Part B of the IDEA deals with children and youth ages 3-21 who receive special education and related services through the public school system (IDEA, 2004). IDEA compliance is enforced by the Office of Special Education and Rehabilitative Services (OSERS).

The third piece of key legislation relevant here is the ADA. ADA affords civil rights protections to individuals with disabilities. These rights are commensurate with those provided to individuals on the basis of race, sex, national origin, and religious beliefs. The ADA assures equal opportunity for those with disabilities in employment, public accommodations, transportation, state and local government services, and telecommunications (OCR, 2011). Title II of the ADA covers private as well as state funded schools such as community colleges, universities, and vocational schools. (OCR, 2011). The Department of Justice or the Equal Employment Opportunity Commission (EEOC) enforce the ADA.

\section{Campus Climate: Faculty, Disability Support Services, and Professional Development}

\section{Considerations}

Campus climate was the next theme that emerged during the literature review process. What initially appeared to be a simple concept turned very complex as multiple variables affect campus climate: mission statements of the college, faculty, professional development, students, accommodations, disability support services, and student perceptions. The overall culture and climate of any postsecondary setting is created from shared values, goals, and actions of all interested parties: students, staff, faculty, and administrators. The shared goals and values on campus determine the level of support and acceptance felt by students with disabilities (Murray \& Flannery, \& Wren, 2008). Colleges that provide for positive 
communication patterns, such as an emphasis on listening, assertive communication, appropriate use of humor and win-win negotiation strategies, help create and support collaborative relationships that lead to greater success of students with disabilities (Shaw \& Dukes, 2006). Students reported that the climate of the college, including the support services office, greatly affected their willingness to seek accommodations (Finn, 1998; Wilson, Getzel, \& Brown, 2000).

Belonging, involvement, purpose, and self-determination have been identified as key factors in the retention of college students - both those with and without disabilities (Shepler \& Woosley, 2012; Wessel, Jones, Markle, \&Westfall, 2009). These factors cannot be fostered by one individual office, such as the office of support services. For this reason, campus climate is such a crucial part of the conversation about students with disabilities in postsecondary settings. The sense of belonging, involvement, purpose, and the ability to advocate for oneself cannot be adequately developed unless a student is able to feel comfortable in their learning environment.

In their 2007 study, Murray, Flannery, and Wren found that the greatest indicator of an accepting campus climate surrounding the needs of students with disabilities was faculty willingness to accommodate and their knowledge of disabilities. This was again shown as a key indictor in two additional studies by Zhang et al. and Cawthorn and Cole (2010). Professional development for faculty was found as the key to creating this culture of acceptance. Faculty knowledge of legal requirements, personal attitudes towards students with disabilities, perceived institutional support, and level of comfort in interacting with students with disabilities can make or break the climate on a campus (Shepler \& Woosley, 2012; Zhang, et al.). However, in a 1994 study, Baggett found that almost three fourths of more than 
400 faculty members and administrators surveyed were unfamiliar with the requirements found within Section 504 and the ADA. Other studies on the same topic found similar results (Vogel, Holt, Sligar, \& Leake, 2008).

Professional development can be key to campus climate for several reasons. When faculty are not prepared to meet the learning needs of students with disabilities, poor graduation rates can be the end result (Lindstrom, 2007; Zhang, et al., 2010). Students reported the perception that faculty can be skeptical regarding the existence of a disability and the need for accommodations (Vogel, Holt, Sligar, \& Leake, 2008). These negative feelings can cause students to feel reluctant to disclose their disability that in turn may lower grades and lead to academic failure (Orr \& Hammig, 2009; Vogel, Holt, Sligar, \& Leake, 2008). The literature also showed that many faculty members have a willingness to make accommodations for students with disabilities but do not know how or do not have enough information to make minor accommodations without feeling uncomfortable about changing course requirements. Many faculty members also incorrectly believe that they are expected to lower academic expectations for students with disabilities (Cawthorn \& Cole, 2010; Jensen, McCrary, Krampe, \& Cooper, 2004; Murray, Flannery, \& Wren, 2008; Zhang et al., 2010). The literature suggested that proper and continued professional development for faculty members would improve the knowledge and attitudes of faculty as well as improve overall campus climate and graduation rates (Lindstrom, 2007; Shaw \& Dukes, 2006; Vogel, Holt, Sligar, \& Leake, 2008).

Faculty must learn different teaching approaches that benefit all students, not just those with disabilities. One such approach discussed in much of the literature is Universal Design for Learning (UDL). UDL is based on the idea that educators who use proactive 
planning can reduce barriers and decrease the need for accommodations, thereby increasing positive learning outcomes (Center on Postsecondary Education and Disability [CPED], 2002; Embry, Parker, McGuire, \& Scott, 2005; Getzel, 2008; Jensen, McCrary, Krampe, \& Cooper, 2004; Orr \& Hammig, 2009; Vogel, Holt, Sligar, \& Leake, 2008). UDL is based on the idea of universal design in architecture, allowing structures to be accessible for all. It is a framework that allows for flexible materials, techniques, and strategies for delivering instruction. Students may then demonstrate mastery of content in a variety of ways. This concept allows for all students to access the content and skills presented in a class (IRIS Center, 2009).

As evidenced in the literature, universities have varied levels of support for students with disabilities. The ADA and Section 504 offer protections that are vaguely written. Most colleges don't implement support with consistency across departments or programs. In addition, faculty receive little to no training at most colleges on teaching students with diverse learning needs (Orr \& Hammig, 2009; Zhang, et. al, 2010). Studies show that faculty would like to "do the right thing" but are mistrustful of how learning disabilities and other hidden disabilities are assessed and desire to protect academic integrity of the classroom (Cawthorn \& Cole, 2010; Jensen, McCrary, Krampe, \& Cooper, 2004; Orr \& Hammig, 2009). However, studies show that faculty are more willing to accommodate for students after disability awareness training (Murray, Flannery, \& Wren, 2009). It has been discussed in the literature that the best method for this personnel development would be through a required, self-paced, online program so that faculty may participate at their convenience (Zhang, et al., 2010). The University of Washington has such a resource available to college faculty. The Faculty Room (http://www.washington.edu/doit/Faculty) is a part of Disabilities, Opportunities, 
Internetworking, and Technology (DO-IT), a federally funded project that provides resources to students, faculty, veterans, administration and support service personnel on postsecondary education and supports for students with disabilities. Online resources for faculty include accommodations and UDL, rights and responsibilities, presentations, and a searchable database of frequently asked questions.

Not surprisingly, the degree of willingness to accommodate for students with disabilities varies by age of faculty member, discipline, and student disability (Orr \& Hammig, 2009; Vogel, Holt, Sligar, \& Leake, 2008). Rush (2011) and Zhang et al. (2010) found that younger faculty who had previous experience with students with disabilities were the most willing to accommodate students with any disability. Physical disabilities were the most willingly accommodated, followed by hidden or learning/attention difficulties. Emotional disabilities were found to be the least willingly accommodated disabilities by faculty (Murray \& Flannery, 2008, Orr \& Hammig, 2009). Faculty in the humanities and social sciences are more likely to accommodate for students than those in the "hard" sciences (e.g., natural, physical, or technological sciences; Orr \& Hammig, 2009). Faculty in schools of education were the most willing overall to provide accommodations (Orr \& Hammig, 2009).

Faculty members who used teaching methods other than lectures alone are also more willing to make accommodations for students with disabilities (Zhang, et al., 2010). During a 2000 study, faculty noted that having students in their classes who had a disability enriched their classes and added diversity. Faculty noted the experience helped them teach to a variety of learning styles and allowed for reflection on their own teaching methodologies (Zhang, et al., 2010). It seems to be supported by the literature that many faculty members who were 
trained during an era of traditional higher education do not have as positive an attitude towards students with disabilities as do faculty members trained more recently.

Disability support offices are tied into the campus climate discussions as well. The Association for Higher Education and Disability (AHEAD) published guidelines that support offices should use when program planning (Appendix B). These guidelines are meant to establish minimum standards for support offices and aim to create consistency among different college campuses. Most faculty rely on the disability support services office on their campus for information regarding not only specific student's needs, but also general disability information as well (Zhang, et al., 2010). The support services office is a "crucial contact for faculty advisors" (AHEAD, 2011, p.1). There also must be a relationship between faculty and support services that extends beyond emails with a list of student accommodations. Most support offices and faculty do not come into contact unless there is a serious problem to be resolved (Jensen, McCrary, Krampe, \& Cooper, 2004; Orr \& Hammig, 2009).

Little research has studied the planning and organizing of support services at the postsecondary level. The literature did suggest that to be successful, the disability services office must be knowledgeable and helpful. Support service staff with a lack of disability knowledge are often perceived as uncaring or offensive by students with disabilities (Burgstahler \& Moore, 2009). More often than not, however, support services are not staffed with disability experts. There are currently only three or four programs that prepare postsecondary disability personnel — these personnel generally have backgrounds in counseling, law, social work, special education, higher education, and rehabilitation. They may or may not have training relating to adult students with disabilities (Shaw \& Dukes, 2006). Many DSS personnel readily admit they are inadequately prepared to meet both 
student and institutional needs (Brinckerhoff, McGuire, \& Shaw, 2002). Trained, approachable staff are integral to fostering a climate of acceptance on campus (Brinckerhoff, McGuire, \& Shaw, 2002; Murray, Flannery, \& Wren, 2009).

In their 2007 study, Trammell and Hathaway detailed the faculty/student relationship as another key to the success of any student. Oftentimes, students with disabilities struggle in forming these relationships (Jensen, McCrary, Krampe, \& Cooper, 2004; Orr \& Hammig, 2009). In a 1993 study, Astin found, based on an earlier study the same year by Tinto (1993), that frequent student-faculty interactions produced positive correlations with student outcomes. This same result was found in a similar study by Pascarella and Terenzini in 2005 (as cited in Mamiseishvili \& Koch, 2011). Students with disabilities may have a more difficult time establishing these key relationships for several reasons. Forty percent of students with disabilities reported having difficulty seeking help from a faculty member when they struggled in a course (Trammell \& Hathaway, 2007). Students with disabilities are likely not to be knowledgeable of their rights and are hesitant to speak to faculty about their needs because of this lack of knowledge. The overall culture of the campus affects whether students with disabilities feel comfortable enough to disclose their learning needs to faculty and foster interpersonal relationships at the same time. The culture of an institution ultimately affects the self-advocacy of the students with disabilities enrolled on its campus. Students are less likely to persist if they are not engaged at least somewhat with faculty or activities on campus (Cawthorn \& Cole, 2010; Mamiseishvili \& Koch, 2011; Skinner, 2004).

\section{Accommodations and Services at the Four-Year Postsecondary Level}

Interconnected with faculty and campus climate, another theme found in the review of literature was accommodations. Under the provisions of Title II the ADA (covering state 
funded schools), Title III of the ADA (covering private and vocational schools) and Section 504 (covering any school that receives federal funds), postsecondary institutions are required by law to provide reasonable accommodations to those students with an identified disability so that they may have equal access to the academic opportunities and services available to their typical peers (National Center for the Study of Postsecondary Educational Supports [NCSPES], 2005; NCSET, 2003). These services are required unless they would fundamentally alter a program or pose an undue financial burden on the college.

Accommodations at the postsecondary level fall into four categories: classroom, testing, learning outside the classroom, and program requirements. Classroom accommodations are selected to support a student with learning during class meetings, such as a note taker. Testing accommodations support students when mastery of learning is being assessed. Interestingly, testing appears to be the most sensitive area of accommodations and the source of most legal action against schools by students with disabilities. Common accommodations in this area are time and a half or an alternate testing environment. Learning outside the classroom accommodations include books on disc or online format. Program requirements are also a delicate area, as they alter program requirements, such as waiving foreign language requirements for students with language and learning disorders. This area of accommodations is generally the most debated by faculty and administrators (Brinckerhoff, McGuire, \& Shaw, 2002).

Earlier research details accommodations that students found most beneficial. According to Finn (1998) students indicated that note takers, proofreaders, and testing accommodations are most useful. Also reported as helpful were writing and math labs available to all students. Other studies report that few students indicated that university 
disability support services were important to their academic success (Cawthorn \& Cole, 2010; Lindstrom, 2007; Nelson, Smith, Appleton, \& Raver, 1993). Many of these students identified to their college disability services office, but then never used any accommodations offered to them. Finn also found that $45 \%$ of students found peer support to be of great help academically, but wanted specialized tutors trained about needs of students with disabilities. These findings show that many students with disabilities are successfully making use of general college supports. However, some students still feel a need for specialized services, some of which are difficult to find because they are expensive and possibly not integral to the success of students with disabilities (Gregg \& Nelson, 2012; Lindstrom, 2007; Trammell, 2009).

Currently, because postsecondary settings are so varied, colleges use different approaches and accommodations to support students with disabilities (Lindstrom, 2007). Small colleges do not have the resources that larger colleges have, but can offer more personalized service— if they employ a staff member skilled in disability support. Larger colleges may have a wider range of service options, but students may feel disconnected from a large services office. Many colleges have poorly developed programs that are not linked to instruction, are seen as informational only, and don't offer support in developing independent learning skills (Brinckerhoff, Shaw, \& McGuire, 1992; NCSPES, 2005). At the same time, at other schools, the services that are offered are becoming more varied and specialized (LD Online, 2004). Inconsistency in services is a significant problem (Schuck \& Kroeger, 1993), especially when studying longitudinal outcomes. Some colleges now offer enhanced services such as summer bridge programs, time management training, study skills, and specialized programs (GAO, 2009; HEATH Resource Center, 2011). These programs were created to 
better meet student support needs and address both transition and lifespan issues beyond specific course accommodations.

In a national survey of all colleges with at least one student with a disability, the following rates of accommodations were reported: $88 \%$ offered extended time, $77 \%$ offered tutors, $69 \%$ offered note takers, $62 \%$ had class registration assistance available, $55 \%$ offered text on tape, $58 \%$ had adaptive technology, and $45 \%$ made sign language interpreters available (Cawthorn \& Cole, 2010). These researchers also found that as many as $25 \%$ of students with disabilities find accommodations offered by their college ineffective. Students most often felt that accommodations were based on the definition of a disability rather than practical accommodations individualized to a student's specific needs. Because the purpose of accommodations is to ensure equal access "it is important to remember that modifications should not be make based on generalization regarding categories of disability, but should be made on a case-by case basis (Section 504 Compliance Handbook, 1999, Section 9, pg. 64). Little efficacy data are available that detail the types of supports most effective and their impact on student success overall in postsecondary settings (Cawthorn \& Cole, 2010; Lindstrom, 2007; Mellard \& Kurth, 2006; NCSET, 2004). Most menus of general accommodations were created some time ago and deserve review for effectiveness-research that is lacking in the current literature.

Services should promote student independence through learning strategy instruction and self-advocacy training within a program that can be individualized to each student (Brinckerhoff, Shaw, \& McGuire, 1992; Getzel, 2008). In addition, several researchers argued that the current menu of services offered to students serve to only create a dependent relationship between student and support services. This dependence cuts away at what could 
be a productive and successful postsecondary education and can impact graduation and employment (Brinckerhoff, Shaw, \& McGuire, 1992; Shaw \& Dukes, 2006). For example, students may receive time and a half on all exams throughout the four years in college. There are few employers who would, or could, give employees that same extended time to finish projects. Thus, it is key that there be some sort of fading process in place to help postsecondary students prepare for the world of employment. Litt and McGuire (1989) described a three-stage process of support services that would address this need. Students would participate in support services from 1 to 3 hours weekly, then 1 to 2 times monthly. Eventually, the students would participate in support services on an as needed basis.

\section{Self-Advocacy: Necessary Skills and Adolescent Development Considerations}

Students with disabilities have consistently identified self-advocacy skills as critical characteristics needed to succeed in postsecondary settings and employment beyond graduation (Shaw \& Dukes, 2006). In seminal research by Gerber \& Reiff (1991), students with learning disabilities identified taking control, advocating for oneself, and reframing one's disability as key to success both in college and employment. Considerable literature is devoted to defining self-advocacy traits, encouraging and teaching advocacy skills, and identifying the success rates of students who use self-advocacy skills effectively. In the course of his qualitative study on students with disabilities and academic achievement in college, Skinner (2004) found eight common themes related to self-advocacy: (1) knowledge of disability, (2) effective accommodations, (3) explanation of psychoeducational evaluation, (4) knowledge of disability law, (5) importance of accommodations and course alternatives, (6) importance of support systems, (7) importance of perseverance, and (8) goal setting. Research shows that most students with disabilities arrive in postsecondary settings with very few of 
these themes developed (Brinckerhoff, McGuire, \& Shaw, 2002; Brinckerhoff, Shaw, \& McGuire, 1992; Getzel, 2008). They may also lack necessary study skills and basic skills necessary to succeed in postsecondary settings and are not prepared to seek out help in these areas without advocacy skills in place.

Both the ADA and Section 504 require self-advocacy for accommodations. This is a new level of responsibility for students entering postsecondary education (Hadley, 2007; PACER Center, 2003). Most of these students are accustomed to high school services and the dependence created by the secondary level support model and mandates of P.L. 94-142 (Cawthorn \& Cole, 2010). Students transition from a very protective environment where school personnel are legally responsible for identification and providing services to an environment where the students are expected to both self-identify and request specific accommodations (Cawthorn \& Cole, 2010; NCSPES, 2005; OCR, 2011).

Current research showed a lack of transition services for students selecting four-year postsecondary education settings. High schools do not adequately inform and prepare students regarding the shift in responsibility to the student between IDEA and the ADA and Section 504 (Hadley, 2007). Along the same lines, research shows that colleges are also lacking in disseminating this information to new students (NCSET, 2004). Research has also demonstrated that students most often know more about the types of services they are provided than knowledge about their specific disability or why they need a particular accommodation or service (Brinckerhoff, McGuire, \& Shaw, 2002; Brinckerhoff, Shaw, \& McGuire, 1992; Cawthorn \& Cole, 2010; Skinner, 2004). Specific disability knowledge would serve to prepare students to advocate, plan, and look beyond to careers (Skinner, 2004). 
In their 2000 study, Palmer and Roessler looked at the effects of a self-advocacy intervention to help postsecondary students with disabilities develop the social skills necessary to request accommodations from faculty. Students were required to meet with faculty outside of class to articulate their accommodation needs rather then have a impersonal letter from the support services office sent to the professor. The treatment group acquired higher levels of self-advocacy skills than the comparison group, but they also developed higher levels of social competence. Support service offices should strive to promote the autonomy and self-advocacy of students with disabilities (Parker \& Boutelle, 2009). These positive skills can be encouraged through direct intervention instruction, as in the intervention developed by Palmer and Roessler or other general studies courses and mentoring with other students with disabilities.

Developmentally, many college freshmen are still considered adolescents; a period marked by uncertainty about self and place in society. It is a period of rapid growth and change marked by the desire for independence (Winston, Miller, \& Cooper, 1999). Adolescents discover new levels of self-awareness and independence, which foster the transition from childhood to adulthood (Field, Hoffman, \& Posch, 1997). The college experience adds to this transition in the areas of autonomy, interpersonal relationships, personal assessment, and goal setting (Winston, Miller, \& Cooper, 1999). Added to this sometimes tumultuous developmental period are many different aspects of disability and how it can affect both interpersonal interactions and impair development as independent students who can advocate for their own learning needs (Trammell, 2009). Many students with disabilities are highly motivated, creative people with a strong drive for success. However, atypical social interactions and behaviors and difficulty with interpersonal relationships can 
be problematic for other postsecondary students with disabilities (Costello \& English, 2001; Mangenello, 1992). Students with disabilities more often lack a positive self-concept and can have additional anger, stress, anxiety, and frustration as a result of their disability (Connor, 2012; Costello \& English, 2001). There is not much current research available in this area. The research that is available most often compares different disabilities (looking at students with lifetime disabilities versus acquired disabilities or students with visible versus invisible disabilities).

These students are also dealing with the physical, cognitive, or behavioral issues associated with their disability, social issues (including stigmatization), and possible increased dependence on family due to their disability (Field, Hoffman, \& Posch, 1997). Deshler (2005) commented that adolescents with disabilities have enduring and unique characteristics that manifest in multiple ways as development and settings change. Often, students at this age are not developmentally ready to be confident self-advocates unless these skills were taught early in their school careers. They may be overly dependent on others, lack a sense of personal strength and competency, and internalize their failures (Costello \& English, 2001; Getzel, 2008)

Students must be able to articulate the accommodations that work best for their own learning style. However, many times students are not given the opportunities in high school to practice these advocacy skills and find themselves ill-prepared to navigate the accommodations process in college. In today's secondary schools, as well as most sectors of society, disabilities are still a taboo topic that are not discussed or acknowledged. Students move on to postsecondary settings with no personal ownership of their disabilities or knowledge of how their disability affects them on a daily basis. Because of this, they also lack 
self-awareness and strategies that could help them in postsecondary settings and beyond. Students in postsecondary settings find a marked decrease in contact among teachers and students, increased academic competition, changes in support networks, and a greater expectation that students will succeed on their own at the postsecondary level (NCSPES, 2005). Students spend 12-15 hours per week in class (perhaps less if carrying a reduced load) compared to 25-30 hours in high school. This shift implies more independent study and reading time for college students (Brinckerhoff, McGuire, \& Shaw, 2002).

\section{Research Design}

The descriptive design for this study was formed by analyzing current research about students with disabilities attending postsecondary settings. According to national Institute for Educational Sciences (IES) data collected by the federal government, students with disabilities are attending postsecondary schools at a growing rate. However, many obstacles still present challenges to these students. Students are not adequately prepared for the transition to postsecondary settings because of the current high school system of support. More often than not they arrive at college with little knowledge about their disability, their legal rights or need for assistance; they also do not possess important self-advocacy skills. Most students want a "fresh start" and, therefore, don't identify themselves to academic support office staff until they begin to struggle. They tend to be uncomfortable discussing their learning needs with faculty and once they begin to fail, they want the support staff to advocate for them. They are then typically offered a generalized menu of services that should fit their disability category, but is not individualized to meet their specific needs. Therefore, according to current literature, accommodations and services may or may not help the student succeed academically. Meanwhile, most students do not receive any self-advocacy or self- 
determination skills training. However, research shows that these are the skills that increase student achievement as well as lifespan outcomes. These findings formed the theoretical framework for this study based on Skinner's 2004 study of students with disabilities transitioning to four-year postsecondary settings.

It was believed that the students in this dissertation study would follow the above behavioral patterns. Also, no published research could be found that compares differences between a public and a private college setting. While a private university may be able to offer smaller, more personalized services; because of its size, it may not be able to offer a wide range of accommodations and services for students with disabilities. A public setting may be seen as large and impersonal, but may have a greater number of students with disabilities enrolled which could indicate more funding and options for accommodations and services. Being as it was an emerging topic in the literature, campus climate in the two different settings might also play a large role in student experiences. One assumption may be that a smaller, private institution, with a personalized, close-knit feel, might have a better campus climate in regards to students with disabilities. Conversely, at a larger institution, the faculty and administration might have more experience with students with disabilities, which as research demonstrates, could possibly create a more receptive climate for students with disabilities. 


\section{Chapter 3: Methodology}

\section{Research Design}

This study was intended to be a cross-sectional, analytical quantitative study of the relationships between student perceptions, self-advocacy awareness, and available disability accommodations at two institutions of higher learning, one public and one private. A quantitative study was selected to maximize the number of student responses that could be collected at two large postsecondary institutions. A student survey was designed as a one-time confidential online survey. An online survey was selected because of the ease of dissemination and data analysis as well as the assumed technology competence of undergraduate students. An online survey was also believed to yield a stronger response rate as it was more convenient for students to complete than a paper survey. A confidential survey was appropriate for this particular study as the information students were to be asked to share was not believed to be so personal in nature as to require an anonymous design. The items included were presented in a variety of ways in order to create sufficient confidence in the consistency of student responses when the same questions were posed in a different manner, as well as to vary the survey in order to keep students engaged.

This survey was based on a pilot study completed by the author earlier on the same topic. Students with disabilities at a small, private liberal arts college were the pilot group for a bank of survey questions based on their experiences with disability support services, their knowledge of their legal rights and responsibilities, and their knowledge and confidence using self-advocacy skills in college. The results of this earlier pilot were used to modify and refine the survey questions that were used in this dissertation study. 


\section{Institutional Review Board Process}

Institutional Review Board (IRB) exemption was received from both the author's supporting university as well as the private college included in the current survey. The public university included in the survey did not require IRB review of studies being completed by outside researchers. Departmental approval was recommended and received by the Director of Disability Support Services (DSS) prior to the survey.

\section{Instrumentation}

Survey items included multiple choice, yes/no, rating scale, and text fill-in questions. The survey content is believed to be internally valid in that the survey items were created with input from experts in the fields of survey design and special education. The online survey was separated into four blocks of questions (copy of instrument can be found in Appendix C) and took approximately 15 minutes to complete. Prior to the survey launch, several volunteers verified the time needed to complete the survey. An introduction to the survey was given, including a rationale and intended outcomes. Participants were then asked if they were over the age of 18 in a yes/no format. Students responding no were exited out of the survey and thanked for their interest. In Block 1, there were four questions. Respondents were first asked: (1) their age of diagnosis as a drop down question, (2) their disability category of their first diagnosis as a multiple-choice, (3) their current disability category as a multiple-choice, and (4) their gender as a multiple choice.

The next set of ten questions in Block 2 pertained to experiences and confidence levels of self-advocacy skills in college and student knowledge of the legal aspects of disability support in college. These items were based on the eight common themes Skinner found in his study on successful postsecondary students with disabilities (Skinner, 2004). The items were 
created based on the themes of: (1) knowledge of disability and (2) effective accommodations; (3) explanation of psychoeducational evaluation; (4) knowledge of disability law; (5) importance of accommodations and course alternatives; (6) importance of support systems; (7) importance of perseverance; and (8) goal setting.

The first question asked about student awareness and confidence with self-advocacy skills as a rating scale. The next yes/no question asked whether the respondent feels comfortable making their own decisions regarding their learning needs. Consultation with others regarding learning needs was asked as a rating scale question. The next two questions were formed as rating scales and assessed student awareness and confidence of traits of successful students. Respondents were then asked two yes/no questions: (1) if they have ever been refused accommodations by a faculty member, and (2) if they had knowledge and understood the parameters of the Americans with Disabilities Act (ADA) and the Individuals with Disabilities Education Act (IDEA).

Students then responded to a question based on their college experiences selfidentifying their disability to others in Block 2 . This was a check-all-that-apply question as to whom they have self-identified to at the college. Then they were asked when and why they self-identified. There were two questions based on self-advocacy skills. The first was a rating scale surrounding student knowledge and self-confidence in this area. The second was a yes/no question about whether the respondent was comfortable making academic decisions without consulting anyone else.

In Block 3, respondents were asked nine questions about their experiences with the Academic Support Services that they have used and if there were any services they would like to see offered at the college. The first two questions asked if the respondent had received 
services (yes/no) and whether they were currently receiving services (yes/no). An item on potentially expanding services and what students would like to have available was included as both a check-all-that-apply question and a fill-in. This block also included a rating scale on accommodations offered by the college they have used and their perceived usefulness. The list of accommodations was generated from online information from the office of disability support for each college. There was also a fill-in question on any other accommodations offered by faculty that they have found useful. Respondents were then asked for the name of the person responsible for coordinating services and documentation in postsecondary settings as a rating scale. Specific questions followed that queried how many times on average the respondent uses the support office each semester (rating scale) and their experiences with the office (rating scale). The last question in this block was a yes/no question and asked if DSS offers services that the respondent feels meet their learning needs and possible services they would like to see offered.

Block 4 had 24 questions and requested further demographic information. Respondents were asked in yes/no format if they have a current psycho-educational assessment, have ever left school because of a disability, if they disclosed their disability at either application or registration, if they had an individualized education plan in elementary and/or high school, and if they understand their learning strengths and weaknesses. They were also asked if they attended a private or public high school as a multiple-choice question. Respondents were then asked to reflect on their high school preparation for college using a multiple choice and yes/no responses. College selection was another set of questions posed using rating scales. Respondents were asked if they attend a private or public postsecondary school, how many schools they applied to, and why they selected their current university. 
Students were then asked using a rating scale whom they consider a part of their academic support system. A rating scale included two items relating to if the respondent felt their college was a good choice for their specific learning needs and if they feel they will meet their goal of graduating from college. Other questions were posed as drop down menus such as major, race and ethnicity, year in school, how many prior schools attended and type (twoyear, four-year), and anticipated graduation date. The final item was a fill-in question and asked if the respondent had any other comments they would like to add.

\section{Data Collection Procedures}

Students who had identified themselves to the disability support office at both schools included in the study were sent a survey invitation by listserv email (Appendix D). The online survey was accessed through Qualtrics at http://www.qualtrics.com. The initial email invitation contained a link that took students directly to the survey. The survey was open with no password required to make it easy for students to participate. Students were able to save their survey and return at a later time if necessary. Students were also given a completion percentage as they worked through the survey. These options were selected to increase the likelihood of students completing the survey. The survey was set to only allow students to complete the survey one time to prevent duplicate responses.

An incentive option was included in the initial email. Students who qualified to participate in the survey were able to enter a drawing for one of ten $\$ 50$ Amazon gift cards at the conclusion of the survey by entering their email address. Students qualified to take the survey by responding that they have, or have had, a diagnosed disability and were over the age of 18 . Students who responded that they did not have a disability and/or were not of legal age for consent were exited out of the survey and thanked for their interest. The online survey 
was open for two weeks for student responses. After the initial email was sent inviting students to participate, a reminder email followed 7 days later.

\section{Research Settings}

Two universities were selected based on proximity to one another, relative size and demographics to other comparative institutions, and each had an office and staff dedicated to student disability support services.

Private University. One university is a private, Carnegie classified Master's College and University, located in the western United States that has both undergraduate and graduate programs. It has 392 full-time and 369 part-time faculty members (National Center for Education Statistics [NCES], 2012). In Fall 2011, there were 5,300 undergraduate students enrolled (NCES, 2012). Ninety-six percent of the undergraduate students attend school fulltime. According to NCES (2012), 4\% of the undergraduate students are registered with the disability services office. The reported characteristics of the undergraduate student population in 2011 are reported in Table 3.

This section intentionally left blank 


\section{Table 3}

Undergraduate Student Population Characteristics from Sampled Universities; 2011

College of Attendance

Demographic Characteristic

Private $\% \quad$ Public $\%$

Gender

Male

$43.0 \quad 44.0$

Female

$57.0 \quad 56.0$

Race and Ethnicity

American Indian or Alaska Native $\quad 0.0 \quad 0.0$

$\begin{array}{lll}\text { Asian } & 9.0 & 22.0\end{array}$

\begin{tabular}{lr} 
Black or African American & 2.0 \\
\hline
\end{tabular}

Hispanic $\quad 13.0 \quad 34.0$

Native Hawaiian or Pacific Islander $\quad 0.0 \quad 0.0$

$\begin{array}{lrr}\text { White } & 60.0 & 29.0\end{array}$

$\begin{array}{lll}\text { Two or more categories } & 4.0 & 3.0\end{array}$

Unknown $\quad 8.0 \quad 5.0$

Non-resident alien $\quad 3.0 \quad 4.0$

Student Age

24 and under

25 and over

$96.0 \quad 80.0$

$4.0 \quad 20.0$

Financial Aid

Grants and Scholarships $\quad 78.0 \quad 41.0$

Financial Aid $\quad 65.0 \quad 28.0$

$\begin{array}{ll}\text { Pell Grants } & 21.0 \quad 36.0\end{array}$

Note. Adapted from the National Center for Education Statistics, College Navigator (2012).

The cost of tuition, on-campus room and board, and books and materials for the 20112012 school year was \$56,341 (National Center for Education Statistics [NCES], 2012).

NCES (2012) reports that of first-time, full-time students who began their studies at this university in the Fall of 2010, 91\% returned the following Fall semester. The retention rate for part-time students during that same period was reported as $100 \%$. The $150 \%$ time graduation 
rate, meaning degree attainment within six years, for students who began their studies in the Fall of 2005 is $72 \%$ (NCES, 2012).

Public University. The second university is a public, Carnegie classified Master's College and University, also in the western United States with both undergraduate and graduate degrees offered. Faculty includes 880 full-time and 955 part-time members (NCES, 2012). In Fall 2011, there were 30,782 undergraduates enrolled (NCES, 2012). Seventy-nine percent of these students are full-time students. Less than $3 \%$ of the undergraduate population has registered with the disability services office at the college (NCES, 2012). The reported characteristics of these students are detailed in the Table 3.

The cost of tuition, on-campus room and board, and books and materials for the 20112012 school year was $\$ 22,220$ for in-state students. Out-of-state student totals were $\$ 33,380$ (NCES, 2012). First-time, full-time students who began their studies in the Fall of 2010 had a retention rate of $85 \%$ for the following Fall semester. The retention rate for part-time students during that same period was reported as $67 \%$. The $150 \%$ time graduation rate for students who began their studies in the Fall of 2005 is 50\% (NCES, 2012).

\section{Participants}

Students were selected for the survey through a non-probability convenience sample. Henry (1990) identified three reasons researchers can defend the use of non-probability samples - (a) lack of resources, (b) inability to identify members of a population, and (c) the need to establish the existence of a problem. A non-probability convenience sample was selected because the time and resources available for this dissertation study prevented the use of a probability sample. Undergraduate students who have, or have had, a disability and were currently enrolled at either of the two selected colleges were the intended sample group. The 
group specifically targeted was undergraduate students who have identified to the academic support office. The survey invitation was sent through the disability support office listserv at both universities. The students included in the listserv email were all students who had registered with the academic support office and were currently enrolled, regardless of whether they received direct services for the semester that the survey was collected. Emails were sent to approximately 1,135 students at both universities. One hundred and sixty-nine students completed the survey. Of those respondents, 113 were eligible to be included in the data analysis. Thirty-four students attended the private university, and 79 students attended the public university. Students were excluded if they did not complete the survey, were not enrolled at the time of the survey, or were graduate students. This made for a $10 \%$ response rate for the survey, which was a similar response rate to the earlier pilot study.

\section{Measures}

The following variables were analyzed from the survey data collected from the two university settings: age, gender, disability category, age of onset of disability, identification pattern (when, why, to whom), awareness of self-advocacy, confidence of self-advocacy, successful student traits, support services used, accommodations, frequency of use, services staff, support services, potential services, high school transition, high school setting, current postsecondary setting, academic support system, year in school, year attendance began, prior colleges, year of anticipated graduation, major, ethnicity, and race.

\section{Data Analysis}

The first sets of data analyses were based on age, race and ethnicity, gender, disability, identification patterns, high school transition, awareness and confidence of advocacy skills and disability law, experience with support services and faculty, and college choice. 
Descriptive statistics, including frequencies, measures of central tendency, and measures of variability were analyzed in order to effectively describe the sample. Chi-square test of independence described the relationships between different groupings of two variables that included: identification patterns, high school transition, current postsecondary setting, awareness and confidence of advocacy skills and disability law, and experiences with postsecondary supports. 


\section{Chapter 4: Results}

The purposes of this study were to gain an increased understanding of the experiences of students with disabilities in four-year postsecondary settings and to use this information to suggest more effective ways to support these students academically. Quantitative student data were gathered from a public and a private four-year postsecondary setting, and descriptive and inferential statistics were analyzed using SPSS statistical software. This chapter outlines the statistical processes utilized to reach conclusions regarding the research questions listed next.

\section{Research Questions}

Four questions guided the research for this dissertation:

1. What are the comparative experiences with academic supports of four-year undergraduate students with disabilities at a private and a public postsecondary setting?

2. What do postsecondary students with disabilities know about self-advocacy skills?

3. How confident are postsecondary students with disabilities using self-advocacy skills?

4. How do self-advocacy awareness and confidence levels influence disclosure patterns for college students with disabilities?

\section{Data Analysis}

Demographic characteristics. In this study, $4 \%$ of students at the private college and less than $3 \%$ of students at the public college are students with disabilities who have verified their disability with the college and receive formal academic support (National Center for Education Statistics [NCES], 2012). Respondents were asked a series of questions to ascertain the demographic characteristics of the survey sample. Descriptive statistics were 
then compiled which revealed information on the following variables: age, gender, race and ethnicity, type of high school attended, prior special education services, type of college attending, year in school, disability category, and major. The mean age of all respondents was 27.5 years $(S D=10.15)$. The mean age of private college participants was 23.3 years $(S D=$ 7.17) with a range of 19-49 years of age. Public college respondents had a mean age of 29.4 years $(S D=10.71)$ with a range of $19-67$ years of age. The majority of total respondents were female (72\%) with males accounting for $28 \%$ of respondents. White (73\%) and Hispanic students (19\%) were the largest race and ethnicity groups represented in the total sample. Disaggregated demographic data by college of attendance are reported in Table 4. The largest disability category represented in the total sample was Other Health Impairments (47\%). Disaggregated disability identification results are included in Table 5. The most common course of study was psychology, with $14.2 \%$ of respondents reporting this as their major. Other areas of study are listed in Table 6.

This section intentionally left blank 


\section{Table 4}

Descriptive Analyses of Demographic Characteristics of Undergraduate Respondents

College of Attendance

Demographic Characteristic

$\underline{\text { Public } \%} \quad \underline{\text { Private } \%}$

Total \% of Respondents

$69.9 \quad 30.1$

Gender

Male

29.1

26.5

Female

70.9

73.5

Race and Ethnicity ${ }^{*}$

American Indian or Alaska Native

0.0

Asian

8.0

8.8

Black or African American

0.0

2.9

Hispanic

25.3

2.9

Native Hawaiian or Pacific Islander

1.3

0.0

White

74.4

76.5

Two or more categories

11.0

2.8

High School Attendance

Public

87.3

55.9

Private

$5.1 \quad 29.4$

Homeschool

Other $^{* *}$

$5.1 \quad 0.0$

$2.5 \quad 14.7$

High School Services

Individualized Education Plan

24.1

35.3

Section 504 Plan

11.4

23.5

Year in School

First Year

10.1

17.6

Second Year

8.9

26.5

Third Year

19.0

32.4

Fourth Year

31.6

11.8

Fifth Year

8.9

8.8

Sixth Year or more

21.5

2.9

\footnotetext{
*Total equals more than $100 \%$ as students were allowed to select one race as well as one ethnicity.

**“Other" responses included: both private and public high school, British schools, and state school for the Deaf.
} 


\section{Table 5}

Descriptive Analyses of Reported Disability Categories by College of Attendance

\begin{tabular}{lcr}
\hline & \multicolumn{2}{c}{ College of Attendance } \\
\cline { 2 - 3 } & $\underline{\text { Public \% }}$ & $\underline{\text { Private \% }}$ \\
Disability Category & 1.3 & 11.8 \\
& 1.3 & 2.9 \\
Autism & 2.5 & 2.9 \\
Deafness & 2.5 & 0.0 \\
Emotional Disturbance & 1.8 & 2.9 \\
Hearing Impairment & 6.3 & 0.0 \\
Intellectual Disabilities & 11.4 & 2.9 \\
Multiple Disabilities & 45.6 & 50.0 \\
Orthopedic Impairment & 16.5 & 17.6 \\
Other Health Impairment & 1.3 & 2.9 \\
Specific Learning Disability & 8.9 & 5.9 \\
Traumatic Brain Injury & & \\
Visual Impairment & & \\
& & \\
\hline
\end{tabular}

Table 6

Descriptive Analyses of Current Major by College of Attendance

College of Attendance

Major

Public $\%{ }^{*} \quad$ Private $\%$

Arts

6.3

32.4

Business

11.4

11.8

Communication

6.3

17.6

Computer Science

1.3

0.0

Education

1.3

2.9

Engineering

1.3

0.0

Health/Human Development

11.4

5.9

Humanities

40.5

23.5

Math

2.5

2.9

Other

2.5

2.9

Science

2.5

0.0

Undeclared

2.5

0.0

\footnotetext{
*Total does not equal $100 \%$ as there were 6 missing responses.
} 


\section{Research Question 1. Public and Private Student Comparative Experiences with}

\section{Academic Supports}

Several dimensions were analyzed to study comparative student experiences in both private and public settings. As a first step in the analysis, descriptive statistics (i.e., measures of central tendency, variability, and distribution) were calculated. To determine the relationship between non-dichotomous variables of interest and private or public university enrollment, a chi-square test of independence was calculated. In instances in which the null hypothesis was rejected, a post-hoc test was calculated to determine the strength of the association between variables. Depending on the number of levels of the independent variable, either a phi or Cramer's V post-hoc test was performed. What follows is a discussion of descriptive and analytic results for each of the dimensions of interest.

Identification Patterns. The question involving student identification patterns pertained to whom the student had identified their disability to on their college campus. Eighty-nine percent of the sample reported that they have identified their learning needs to the Disability Support Services (DSS) office. Eighty-nine percent of students have also discussed their learning needs with a faculty member on campus. Only $54 \%$ of students have identified to their academic advisor, while $74 \%$ have discussed their needs with other students. Thirtynine percent of students reported discussing their academic needs with other support staff, which are listed as residence hall staff, career services, and health services. Disaggregated data are detailed in Table 7. Measures of association were then analyzed and the null hypothesis was accepted for all variables. An association between school of attendance and whom a student chooses to disclose their learning needs to on their campus does not appear to exist. 


\section{Table 7}

Descriptive and Associative Analyses of Whom Students Have Identified to at Their College by College of Attendance

\begin{tabular}{lcrcr}
\hline & \multicolumn{2}{c}{ College of Attendance } & \\
& \multicolumn{2}{c}{} & \\
Person Student has Identified To & Public \% & Private \% & $\mathrm{X}^{2}$ \\
& & & \\
\hline DSS & 88.6 & 91.1 & 0.055 \\
College Faculty Member & 89.8 & 88.2 & 0.067 \\
Academic Advisor & 56.9 & 47.0 & 0.938 \\
Other Students & 74.6 & 70.5 & 0.204 \\
Other Support Staff & 37.9 & 41.1 & 0.102 \\
& & & \\
\hline
\end{tabular}

The second question posed to students regarding identification patterns asked them to identify what event triggered self-identification to their college. For both private and public school students, most self-identified after struggling in a class (38\%), followed by identification at the time of initial application to the school (32\%). Twenty percent of students identified to their college when they registered. Seven percent identified when they received a poor final grade in a class and $3 \%$ chose to identify when they had trouble in a non-academic area, such as health or housing. Disaggregated data are detailed in Table 8. For this question, no relationship was found between public and private university attendance and the event that caused a student to identify to their school. The null hypothesis was accepted, $X^{2}(4, N=113)=$ $2.395, p>0.5$. 


\section{Table 8}

Descriptive Analyses of Precipitating Event That Led Students to Identify to Their College by College of Attendance

\begin{tabular}{lrr}
\hline & \multicolumn{2}{c}{ College of Attendance } \\
\cline { 2 - 3 } Event & Public \% & Private \% \\
& & \\
\hline Application & 27.8 & 41.2 \\
Registration/Enrollment & 20.3 & 20.6 \\
Struggled in a Class & 41.8 & 29.4 \\
Received a Poor Final Grade & 7.6 & 5.9 \\
Other Non-Academic Issue & 2.5 & 2.9 \\
& & \\
\hline
\end{tabular}

Students were also queried about when they identified to their college. Twelve percent of all respondents in the sample identified to their college during their second semester of enrollment. The next largest group (11\%) identified during their second year of college. Nine percent identified to their college during their first semester. Another $10 \%$ of students identified during their third year at school, $5 \%$ identified during their fourth year, and 2\% chose to identify to their school during their fifth year or later. Disaggregate data by school of enrollment is shown in Table 9. No relationship was found through a chi square test of independence between when a student chose to identify to their college and school of attendance, $\mathrm{X}^{2}(5, \mathrm{~N}=113)=6.488, p>0.5$. 


\section{Table 9}

Descriptive Analyses of When Student Chose to Identify to Their College by College of Attendance

College of Attendance

\begin{tabular}{lrr} 
Year in School & Public \% & Private \% \\
\hline First Semester & 14.6 & 30.8 \\
Second Semester & 22.0 & 30.8 \\
Second Year & 29.3 & 0.0 \\
Third Year & 19.5 & 23.1 \\
Fourth Year & 12.2 & 7.7 \\
Fifth Year or Later & 2.4 & 7.7 \\
& & \\
\hline
\end{tabular}

Accommodations Utilized. Ninety-three percent of the 113 students surveyed have received direct accommodation services from their office of DSS at some point in college. For the current semester during the survey window, $81 \%$ of students were receiving services from their office of DSS. Table 10 details the services and disaggregated descriptive analyses for accommodations. 
Table 10

Descriptive and Associative Analyses of Accommodation Services Students Have Used by College of Attendance

College of Attendance

Accommodation Used

Private $\% \quad$ Public $\% \quad X^{2} \quad \phi$

\begin{tabular}{|c|c|c|c|c|}
\hline Adaptive Equipment & 0.0 & 12.6 & 4.722 & 0.204 \\
\hline Advising Services & 35.2 & 39.2 & 0.157 & \\
\hline Alternative Seating & 17.6 & 29.1 & 1.638 & \\
\hline Alternative Examination & 76.4 & 70.8 & 0.372 & \\
\hline Alternative Text & 14.7 & 20.2 & 0.483 & 0.650 \\
\hline Captioning Services & 11.7 & 2.5 & 4.030 & 0.189 \\
\hline Consultation with & & & & \\
\hline $\begin{array}{l}\text { Faculty on Behalf of } \\
\text { Student }\end{array}$ & 20.5 & 13.9 & 0.788 & \\
\hline Diagnostic Assessment & 11.7 & 12.6 & 0.017 & \\
\hline Documentation Sent to & & & & \\
\hline $\begin{array}{l}\text { Faculty on Behalf of } \\
\text { Student }\end{array}$ & 52.9 & 50.6 & 0.051 & \\
\hline Note Taker & 26.4 & 26.5 & 0.00 & \\
\hline Parking Arrangements & 14.7 & 7.5 & 1.368 & \\
\hline Peer Tutoring & 35.2 & 17.7 & 4.143 & 0.191 \\
\hline Proofreader & 5.8 & 11.3 & 0.821 & \\
\hline Psychological Services & 2.9 & 24.0 & 0.075 & \\
\hline Reader Services & 8.8 & 18.9 & 1.834 & \\
\hline $\begin{array}{l}\text { Referrals to Outside } \\
\text { Agencies }\end{array}$ & 2.9 & 11.3 & 2.105 & \\
\hline Registration Assistance & 29.4 & 53.1 & 5.399 & 0.219 \\
\hline $\begin{array}{l}\text { Sign Language } \\
\text { Interpretation }\end{array}$ & 8.8 & 1.2 & 3.976 & 0.188 \\
\hline $\begin{array}{l}\text { Specialized Computer } \\
\text { Lab Access }\end{array}$ & 0.0 & 20.2 & 8.022 & 0.266 \\
\hline Specialized Software & 11.7 & 21.5 & 1.495 & \\
\hline Substitute Coursework & 2.9 & 7.5 & 0.886 & \\
\hline Transcription & 5.8 & 7.5 & 0.106 & \\
\hline Voice Recorder & 23.5 & 39.2 & 2.596 & \\
\hline Writing Center & 23.5 & 29.1 & 0.372 & \\
\hline
\end{tabular}


For seventeen of the standard accommodations, no differences between public and private university students with disabilities and the accommodation were detected. In all of these instances, the null hypothesis was accepted. Seven accommodations were found to have significant relationships with school of attendance, lending support for the acceptance of the alternative hypothesis. The first chi-square test of independence that resulted in an acceptance of the alternative hypothesis was calculated comparing the frequency of registration assistance between students at public and private universities. A significant relationship was found, $\mathrm{X}^{2}(1, \mathrm{~N}=113)=5.399, p>.05$. Students who attend the public university $(81 \%)$ are more likely to use registration assistance as an accommodation than private university students (19\%). A phi post-hoc was then completed and found that the strength of the relationship to be moderate $(\phi=0.219)$. Peer tutoring was also found to be dependent on school of attendance. A significant relationship was found, $X^{2}(1, N=113)=$ $4.143, p>.05$. Students who attend public universities (54\%) are more likely to participate in peer tutoring than their private school counterparts (46\%). This was found to be a moderately strong relationship $(\phi=0.188)$. Further research indicated peer tutoring is offered at the public university as a DSS accommodation. At the private university, peer tutoring is offered as a general support to all students on campus.

The alternative hypothesis was also accepted when looking at the accommodations of sign language interpretation and captioning for students with hearing impairments. Sign language interpretation and school of attendance were found to have a moderately significant relationship, $\mathrm{X}^{2}(1, \mathrm{~N}=113)=3.976, p>.05, \phi=0.188$. Students were more likely to attend a public university and use sign language interpreting services than utilize these services at a private university. As for captioning services, the same significance was found. Students were 
more likely to attend a public college and use captioning services as an accommodation than attend a private college. This was also found to be a moderately significant relationship, $\mathrm{X}^{2}(1$, $\mathrm{N}=113)=4.030, p>.05, \phi=0.189$

Alternative texts were another area that demonstrated relationships between school of attendance and accommodation. Students at the public university surveyed were more likely to utilize alternative formats of text $(76 \%)$ than their peers at the private university $(24 \%)$. These two variables were found to have a strong association, $\mathrm{X}^{2}(1, \mathrm{~N}=113)=.0483, p>0.5, \phi$ $=0.65$. The null hypothesis was also rejected when looking at the relationship between school of attendance and adaptive equipment use. Students at the public college were more likely $(100 \%)$ to use adaptive equipment than students at the private college $(0 \%)$. This relationship was found to be moderately significant, $\mathrm{X}^{2}(1, \mathrm{~N}=113)=4.722, p>0.05, \phi=0.204$. This same pattern was found with the accommodation of specialized computer lab access. Students at the public university $(100 \%)$ were more likely to use this accommodation than students at the private university $(0 \%)$. This was again a moderately significant relationship, $X^{2}(1, N=113)=$ 8.022, $p>0.05, \phi=0.266$.

Usefulness of Accommodations. Respondents were asked about their perceptions of usefulness of accommodations offered by their college. Students were first asked if they had used a particular accommodation, then rated each accommodation they had utilized with the following rating scale: (1) not useful at all, (2) not useful, (3) useful, or (4) very useful. Descriptive data are listed in Table 11. Upon a chi square analysis of independence of each accommodation, no relationship was found between student perceptions of useful accommodations and either private or public school attendance. 


\section{Table 11}

Descriptive and Associative Analyses of Student Perceived Usefulness of Accommodations

\begin{tabular}{|c|c|c|c|c|c|}
\hline \multirow[b]{2}{*}{ Accommodation } & \multicolumn{2}{|c|}{$\underline{M}$} & \multicolumn{2}{|c|}{$\underline{S D}$} & \multirow[t]{2}{*}{$X^{2}$} \\
\hline & Public & Private & Public & Private & \\
\hline Adaptive Equipment & 2.33 & 1.33 & 1.414 & 0.354 & 4.953 \\
\hline Advising & 3.13 & 2.36 & 1.044 & 1.216 & 4.876 \\
\hline Alternative Exam & 3.61 & 3.59 & 0.766 & 0.971 & 3.506 \\
\hline Alternative Seating & 2.88 & 2.22 & 1.320 & 1.481 & 2.271 \\
\hline Alternative Texts & 2.65 & 2.33 & 1.402 & 1.581 & 1.965 \\
\hline Captioning Services & 1.41 & 1.78 & 1.004 & 1.302 & 0.816 \\
\hline Computer Lab Access & 2.59 & 1.50 & 1.436 & 1.069 & 4.385 \\
\hline Consultation with Faculty & 2.25 & 2.67 & 1.293 & 1.497 & 3.236 \\
\hline Diagnostic Assessment & 2.23 & 1.67 & 1.378 & 1.211 & 1.421 \\
\hline $\begin{array}{l}\text { Documentation Sent to } \\
\text { Faculty }\end{array}$ & 3.25 & 3.38 & 1.037 & 1.071 & 3.912 \\
\hline Note taker & 2.24 & 2.13 & 1.251 & 1.246 & 0.165 \\
\hline Parking Arrangements & 1.90 & 2.40 & 1.294 & 1.506 & 4.118 \\
\hline Peer Tutoring & 2.54 & 2.86 & 1.215 & 1.231 & 1.538 \\
\hline Proofreader & 2.14 & 2.40 & 1.167 & 1.506 & 4.006 \\
\hline Reader Services & 2.81 & 2.56 & 1.357 & 1.509 & 1.101 \\
\hline $\begin{array}{l}\text { Referrals to Outside } \\
\text { Agencies }\end{array}$ & 2.09 & 1.38 & 1.342 & 1.061 & 3.009 \\
\hline Registration Assistance & 3.58 & 3.29 & 0.763 & 1.139 & 3.045 \\
\hline School-based Counseling & 2.72 & 2.62 & 1.250 & 1.325 & 1.842 \\
\hline $\begin{array}{l}\text { Sign Language } \\
\text { Interpretation }\end{array}$ & 1.06 & 1.75 & 0.250 & 1.389 & 4.714 \\
\hline Specialized Software & 2.37 & 2.50 & 1.391 & 1.434 & 0.119 \\
\hline Substitute Coursework & 1.80 & 1.86 & 1.152 & 1.464 & 2.373 \\
\hline Transcription Services & 1.89 & 1.75 & 1.132 & 1.389 & 3.701 \\
\hline Voice Recorder & 3.00 & 2.55 & 1.210 & 1.368 & 1.876 \\
\hline Writing Center & 2.82 & 2.75 & 1.029 & 1.357 & 1.876 \\
\hline
\end{tabular}

Note. $\mathrm{p}>0.5$

Student Support Experiences. To gain information about the support experiences of undergraduate students with disabilities, several responses were analyzed regarding interactions students have had with DSS and school faculty. The following dimensions were included in descriptive and associative analyses: faculty refusal of services, average contacts 
with DSS, student satisfaction with DSS office personnel, DSS support offerings, overall confidence with school choice, and overall satisfaction with support the student receives at their college.

Refusal of Services. The first area analyzed in student support experiences was faculty support. Students were asked to report if a faculty member had ever denied them services. If they answered in the affirmative, they were also asked to describe what action they had taken. Most students (85\%) reported that they have not had a faculty member refuse services. Fifteen percent reported a faculty member had refused them services. When disaggregated, $88.6 \%$ of public college students and $76.5 \%$ of private college students reported they have never had a faculty member refuse to provide services. After a chi square test of independence, no association was found between public and private school students and faculty refusal of services, $\mathrm{X}^{2}(1, \mathrm{~N}=113)=2.740, p>0.5$.

Students that had been refused services by a faculty member reported the following when asked what action they had taken:

- "dropped the class $[$ sic $] "$

- "reported the teacher to the union and the college $[$ sic $] "$

- "Told him in class in front of other students that he was wrong and that he would be reported."

- "Told other students not to take that teacher's class."

- "dealt with it on my own [sic]"

- "Educate $[$ sic $]$ them about my needs and why they are important. Also, inform [sic] Disability services to have some bite to my bark."

- "explain why I need them $[$ sic $] "$ 
- "I didn’t know what to do."

- "I have had this happen on several different occasions with several different people. I have written a formal letter to the Dean to get my required accommodations, and I have cited the American Disability Act explaining that given [sic] me the accommodation isn't optional, but legally required."

- "reported the professor to the dean of students [sic]"

- "Reported to DSS which did not help."

- "talked [sic] to my counselor at the disability center."

- "They accommodated me in another class for longer or their office."

- "We had to make an argument and prove that the disability was real."

- "went to DSS [sic]"

Contacts with Academic Support Office. Students were asked how many times they contact the DSS office per semester. The mean response was $9.56(S D=10.75)$ contacts per semester for all respondents. Public college respondents had a mean of $9.85(S D=10.79)$ and private college participants had a mean of $8.87(S D=10.80)$. After a chi-square test of independence was completed, it was determined that no relationship exists between public or private college attendance and frequency of contact with the office of disability support, $\mathrm{X}^{2}(24, \mathrm{~N}=113)=35.443, p>0.5$.

Student Satisfaction with Available Supports. Students were asked about their satisfaction with individual academic supports at their college. A rating scale was given to students, which included the answer choices: (1) very unsatisfied, (2) unsatisfied, (3) satisfied, and (4) very satisfied. Descriptive data are reported in Table 12. A chi-square test of independence was completed to ascertain any relationship between the dichotomous variables 
of student satisfaction and public or private school attendance. The null hypothesis was accepted for each satisfaction question; there was no perceived relationship between school of enrollment and academic support satisfaction.

Table 12

Descriptive and Associative Analyses of Student Satisfaction with Academic Support Office by College of Attendance

\begin{tabular}{|c|c|c|c|c|c|}
\hline \multirow[b]{2}{*}{ Satisfaction } & \multicolumn{2}{|c|}{$\underline{M}$} & \multicolumn{2}{|c|}{$\underline{S D}$} & \multirow[t]{2}{*}{$\underline{X^{2}}$} \\
\hline & Public & Private & Public & Private & \\
\hline Communication with Student & 3.33 & 3.50 & 0.763 & 0.564 & 2.563 \\
\hline $\begin{array}{l}\text { Communication with Faculty } \\
\text { on Behalf of Student }\end{array}$ & 3.19 & 3.35 & 0.878 & 0.691 & 2.169 \\
\hline Documentation Process & 3.31 & 3.35 & 0.744 & 0.597 & 3.634 \\
\hline Documentation Requirements & 3.30 & 3.41 & 0.806 & 0.557 & 2.931 \\
\hline Efficiency of Office & 3.28 & 3.47 & 0.816 & 0.706 & 1.665 \\
\hline Approachability of Staff & 3.44 & 3.68 & 0.764 & 0.589 & 2.842 \\
\hline Helpfulness of Staff & 3.47 & 3.68 & 0.731 & 0.589 & 2.990 \\
\hline Respect Towards Students & 3.61 & 3.79 & 0.649 & 0.410 & 2.780 \\
\hline Disability Knowledge of Staff & 3.49 & 3.59 & 0.658 & 0.701 & 4.164 \\
\hline $\begin{array}{l}\text { Accommodation Knowledge of } \\
\text { Staff }\end{array}$ & 3.58 & 3.47 & 0.612 & 0.825 & 2.023 \\
\hline Support Knowledge of Staff & 3.30 & 3.38 & 0.790 & 0.739 & 1.185 \\
\hline $\begin{array}{l}\text { Academic Programs } \\
\text { Knowledge Level of Staff }\end{array}$ & 3.33 & 3.50 & 0.746 & 0.615 & 1.744 \\
\hline $\begin{array}{l}\text { Availability of Disability } \\
\text { Education Programs }\end{array}$ & 3.29 & 3.18 & 0.834 & 0.834 & 2.214 \\
\hline
\end{tabular}

Academic Support Service Offerings. Respondents were asked to indicate what support services were currently offered through their DSS office with a yes or no response. A subsequent item asked what services respondents would like to see offered at their college, also with a yes or no response. Descriptive data are listed by accommodation in Table 13. 
Table 13

Descriptive Analyses of Student Reported Services Currently Offered Through the Academic Support Office at Their College; Services Students Would Like to See Offered

\begin{tabular}{|c|c|c|c|c|}
\hline \multirow[b]{2}{*}{ Service } & \multicolumn{2}{|c|}{$\frac{\text { Currently }}{\text { Offered }}$} & \multicolumn{2}{|c|}{$\frac{\text { Would Like to }}{\underline{\text { See Offered }}}$} \\
\hline & $\begin{array}{c}\text { Public } \\
\%\end{array}$ & $\begin{array}{c}\text { Private } \\
\%\end{array}$ & $\begin{array}{c}\text { Public } \\
\%\end{array}$ & $\begin{array}{l}\text { Private } \\
\quad \%\end{array}$ \\
\hline Community Building & 34.2 & 20.6 & 46.8 & 29.4 \\
\hline Mentoring & 39.2 & 32.4 & 46.8 & 32.4 \\
\hline $\begin{array}{l}\text { Mentoring with Older Student } \\
\text { with Similar Disability }\end{array}$ & 16.5 & 11.8 & 67.1 & 41.2 \\
\hline Orientation Presentation & 34.2 & 20.6 & 41.8 & 41.2 \\
\hline Other & 17.7 & 8.8 & 27.8 & 20.6 \\
\hline Self-Advocacy Training & 39.2 & 5.9 & 53.2 & 47.1 \\
\hline Social Media Connections & 13.9 & 11.8 & 50.6 & 26.5 \\
\hline $\begin{array}{l}\text { Tutoring with Disability } \\
\text { Specialist }\end{array}$ & 27.8 & 17.6 & 55.7 & 52.9 \\
\hline
\end{tabular}

Students who responded in the affirmative to the last service, other, were asked to detail what other services they would like to see offered. The fill-in responses are transcribed below:

- "A place to rest when I feel my symptoms. There is NO WHERE TO GO! Even when I see a nurse on campus and all I need to do is lie down for a few minutes to calm down, I am told to go to the Alumni office and sit in a frigging chair! I would go home but I commute to school and cannot afford to be missing classes. So I have had to suffer! Imagine, seeing a nurse, blood pressure off the charts anxiety ridden and being told to walk across campus and to sit in a public area to try to recuperate. 
Disgsting. [sic]"

- "Academic advisor who can help me plan the classes I should take and how it will challenge my disability. Also who can help me plan out my semester, etc. Basically someone I know personally who I can talk to for advice, etc.. I have tried using my academic advisor, but like many other business majors she is extremely unhelpful, rude, and every time I go there I leave feeling confused, misguided, and like she had no interest in helping me so it would be really nice to have someone to go to."

- "Alternative Study Technique, Brainstorming Seminar"

- "Another room for the students with disabilities to study, and get help with computer problems when the computer lab is closed in the DSS office. We have another computer lab, but no one is there in the library to help the students when a program is not working. There needs to be someone that can be on call when a student is having trouble with their specific software. It would be nice to have specific tutors to help those with learning disabilities. It would be helpful if the student can make an appointment with such a tutor."

- "Elevators in inaccessible buildings. I understand that they are "historical" and that classes with disabled students can be relocated, but this sends the message that the problem of inaccessibility can be solved just by moving disabled students elsewhere. Accessibility for all individuals should be the college's priority. I'm not paying fortyplus grand a year only to be able to access part of the campus."

- "Events for disabled students and students with psychological issues as well"

- "groups that focus on survival skills for student with ADHD [sic]"

- "I think it would be beneficial to have core academic advisement sessions when 
students are selecting classes."

- "I would like to see counselors at the satellite campus."

- "I would like to see orientations for other students beside incoming freshmen...no service that I am aware of for transfer students of any kind.”

- "I would like to stress counseling available through the Disabled Student Services."

- "Job placement services after graduation from a credential, certificate, or degree program."

Chi-square tests of independence were completed to analyze relationships between the services offered/would like to see offered and the variable of public or private attendance. Table 14 details the results of these analyses. A strong relationship was found between college of attendance and self-advocacy skills training. Students at the public college (39\% of public college students in the survey) responded that self-advocacy skills training is available at their college. A moderate association was found between college of attendance and the desire for mentoring with an older student with a disability. Sixty-seven percent of all public college respondents would like to see mentoring with another student with a disability offered on their campus. A moderate relationship was also found between school of attendance and a desire for social media connections. Of all public college participants, $51 \%$ would like to see social media connections offered through their DSS office. 
Table 14

Associative Analyses of Student Reported Services Currently Offered Through the Academic Support Office at Their College; Services Students Would Like to See Offered

\begin{tabular}{|c|c|c|c|c|}
\hline \multirow[b]{2}{*}{ Service } & \multicolumn{2}{|c|}{$\frac{\text { Currently }}{\underline{\text { Offered }}}$} & \multicolumn{2}{|c|}{$\frac{\text { Would Like to }}{\text { See Offered }}$} \\
\hline & $X^{2}$ & $\phi$ & $X^{2}$ & $\phi$ \\
\hline Community Building & 2.087 & & 2.970 & \\
\hline Mentoring & 0.483 & & 2.040 & \\
\hline $\begin{array}{l}\text { Mentoring with Older Student } \\
\text { with Similar Disability }\end{array}$ & 0.409 & & 6.612 & 0.242 \\
\hline Orientation Presentation & 2.087 & 0.102 & 0.003 & \\
\hline Other & 1.472 & & 0.657 & \\
\hline Self-Advocacy Training & 12.793 & 0.336 & 0.355 & \\
\hline Social Media Connections & 0.096 & & 5.650 & 0.224 \\
\hline $\begin{array}{l}\text { Tutoring with Disability } \\
\text { Specialist }\end{array}$ & 1.327 & & 0.730 & \\
\hline
\end{tabular}

Note. $p>0.05$

Confidence in School Choice. Students were asked if they felt confidence in their school choice in relation to their specific academic support needs. Students were asked if they: (1) strongly disagreed, (2) disagreed, (3) agreed, or (4) strongly agreed with the statement I believe this college was a good choice for my specific learning needs. Of the total sample, $90 \%$ of students agreed that they had confidence in their choice of school in relation to their learning needs $(M=3.42, S D=0.664)$. The mean response for public college participants was $3.38(S D=0.666)$ and the mean response for private college participants was 
$3.50(S D=0.663)$. A chi-square test of independence was completed and the null hypothesis was accepted, $\mathrm{X}^{2}(2, \mathrm{~N}=113)=1.115, p>.05$.

Overall Satisfaction With Academic Support Office. Students were asked to rate the following statement: I feel supported by the Academic Support Office at this college using the following rating scale: (1) strongly disagree, (2) disagree, (3) agree, or (4) strongly agree. Ninety percent of all respondents felt supported at their college $(M=3.42, S D=0.765)$. The mean response for public college participants was $3.44(S D=0.747)$ and the mean response for private college participants was $3.38(S D=0.817)$. A chi-square analysis was then completed and no association was found between public or private university and feelings of support, $\mathrm{X}^{2}(3, \mathrm{~N}=113)=2.852, p>.05$.

\section{Research Question 2. Postsecondary Student Knowledge Regarding Self-Advocacy Skills}

The questions posed in the survey regarding self-advocacy awareness were not specific to experiences at either a public or private institution, so no disaggregation was made in the resulting data analyses. Descriptive data were analyzed to determine measures of central tendency, variability, and distribution description for each variable pertaining to selfadvocacy skills awareness. The following is a discussion of descriptive results for each of the dimensions of interest.

Awareness of self-advocacy skills. Students were asked about their awareness of selfadvocacy skills in an academic setting. Students used a rating scale to demonstrate their agreement with the statement I am aware of the self-advocacy skills needed to be successful in college: (1) strongly disagree, (2) disagree, (3) agree, (4) strongly agree. The mean for selfadvocacy awareness was 3.30 with an SD of 0.925 . Fifty-six percent of respondents strongly 
agree and 25\% agreed they have self-advocacy awareness. Thirteen percent disagreed, and $6 \%$ strongly disagreed they are aware of self-advocacy skills.

Students were asked if they received any self-advocacy skills training in either high school or college. Responses were again based on the rating scale: (1) strongly disagree, (2) disagree, (3) agree, (4) strongly agree. The high school training mean was 1.54 with an SD of 0.916. Six percent of students strongly agreed they had received self-advocacy skills training in high school. Of the remaining responses, $11 \%$ selected agree, 14\% selected disagree, and $69 \%$ selected strongly disagree. The college training mean was 1.88 with an SD of 1.033 . Ten percent of students surveyed strongly agreed they had received self-advocacy training in college. Another $19 \%$ agreed they had received advocacy training in college, $22 \%$ disagreed, and $50 \%$ strongly disagreed.

Awareness of successful student factors. Students were asked a series of questions based on the successful student factors Skinner outlined in his 2004 study. Skinner found the following practices common among successful postsecondary students with disabilities: (1) the ability to describe learning needs, (2) following daily routines, (3) having clear goals, (4) knowing stress management techniques, (5) participation in on-campus, non-academic activities, (6) seeking help with personal difficulties, (7) making own academic decisions, (8) having a balanced life (work, school, friends, family), (9) having outside interests, (10) reading about successful students with disabilities, (11) being able to describe personal strengths and weaknesses, (12) trying different accommodations to find the most effective, and (13) reviewing most recent psycho-educational or medical assessment. Students were asked to rate a series of statements based on these success indicators using the scale: (1) strongly disagree, (2) disagree, (3) agree, (4) strongly agree. 
The ability to describe my learning needs makes me a successful student. The mean response for this first statement was 3.17 with an SD of 0.855 . Forty-two percent of respondents strongly disagreed with the first statement. Another 38\% disagreed, $16 \%$ agreed, and $4 \%$ strongly agreed that the ability to describe their learning needs makes a successful student.

Following a daily routine makes me a successful student. The mean response for this statement was 3.21 with an SD of 0.832 . Forty-three percent of students strongly agreed and $40 \%$ agreed with this statement. Twelve percent of students disagreed and $4 \%$ strongly disagreed that following a routine makes them a successful student.

Having clear goals makes me a successful student. The mean response for this statement was $3.58(S D=0.580)$. Sixty-two percent of respondents strongly agree and $33 \%$ agree with this statement. The remaining $4 \%$ of students disagreed that having clear goals is a factor in student success.

Knowing stress management techniques makes me a successful student. With a mean response of $3.42(S D=0.716), 53 \%$ of students strongly agreed and $37 \%$ agreed that stress management techniques are a factor in student success. Another $8 \%$ of respondents disagreed and $2 \%$ strongly disagreed that knowledge of stress management techniques lead to academic success.

Participating in non-academic, on campus activities makes me a successful student. The mean response to this statement was 2.49 with an SD of 1.036 . Twenty percent of students strongly agreed and $31 \%$ of students agreed that participation in campus activities leads to student success. Twenty-eight percent disagreed and $21 \%$ strongly disagreed with this statement. 
Seeking help when I have personal difficulties makes me a successful student. With a mean response of $3.42(S D=0.692)$, most respondents $(53 \%)$ strongly agreed with the statement regarding seeking help during times of personal difficulty. Thirty-seven percent of students agreed with the statement, while $9 \%$ disagreed and 1\% strongly disagreed.

Making my own academic decisions makes me a successful student. The mean response for this statement was 3.33 with an SD of 0.731 . Again, most respondents $(45 \%)$ strongly agreed that academic decision autonomy leads to academic success. Forty-one percent of students agreed with this statement, $10 \%$ disagreed, and $2 \%$ strongly disagreed that independent decision-making is a factor in student success.

Having a balanced life makes me a successful student. With a mean of $3.46(S D=$ 0.768), the majority of participants (60\%) strongly agreed that seeking a balance in life leads to student success. Another $28 \%$ of students agreed, $9 \%$ disagreed, and 3\% strongly disagreed with the statement.

Having interests outside this college makes me a successful student. The mean response of this statement was 3.33 with an SD of 0.807 . Fifty percent of students strongly agreed and $35 \%$ of students agreed that having outside interests is a factor in being a successful student. Eleven percent disagreed and 4\% strongly disagreed that having outside interests contributes to being a successful student.

Reading about successful college students with disabilities or attention disorders makes me a successful student. With a mean of $2.41(S D=1.131), 23 \%$ of respondents strongly agreed, and 20\% agreed that reading about other students with disabilities increases student success. Twenty-eight percent disagreed and $27 \%$ strongly disagreed with the statement regarding reading about students with disabilities. 
Being able to describe my personal strengths and weaknesses makes me a successful

student. The mean response of this statement was 3.30 with an SD of 0.801 . Most students ( $46 \%$ strongly agreed and $43 \%$ agreed) that the ability to describe strengths and weakness does affect academic success. Five percent of students disagreed with the statement and 5\% strongly disagreed with the statement.

Trying out different accommodations to find the ones that benefit me most makes me a successful student. With a mean of $3.30(S D=0.865)$, a predominance of respondents (51\% strongly agree and 33\% agree) believed that trying out accommodations makes for a successful student. Eleven percent of participants disagreed and 5\% strongly disagreed with the statement regarding accommodations.

\section{Reviewing my most recent psycho-educational or medical assessment makes me a} successful student. The mean of this statement was 2.65 with an SD of 1.085. Twenty-eight percent of students strongly agreed and $27 \%$ of students agreed with the statement regarding review of assessments. Twenty-seven percent disagreed and 19\% strongly disagreed that being aware of assessment results leads to student success.

Legal and Transition Education. Respondents were asked about their history with legal rights education and transition preparation. Questions were posed to participants about their high school transition plan relating to college and how their high school and college prepared them with knowledge about transition and their legal rights. Responses were rated as (1) strongly disagree, (2) disagree, (3) agree, or (4) strongly agree. Descriptive analyses are included in Table 15. 
Table 15

Descriptive Analyses of Past Legal and Transition Education

\begin{tabular}{|c|c|c|c|c|}
\hline \multirow[b]{2}{*}{$\begin{array}{l}\text { Legal and Transition } \\
\text { Education }\end{array}$} & \multicolumn{2}{|c|}{$\underline{M}$} & \multicolumn{2}{|c|}{$\underline{S D}$} \\
\hline & Public & Private & Public & Private \\
\hline $\begin{array}{l}\text { Student had a Transition Plan } \\
\text { Written for a Four-year } \\
\text { College }\end{array}$ & 1.51 & 2.00 & 0.990 & 1.255 \\
\hline $\begin{array}{l}\text { High School Prepared } \\
\text { Student for Transition to a } \\
\text { Four-year College }\end{array}$ & 1.78 & 2.38 & 1.112 & 1.349 \\
\hline $\begin{array}{l}\text { DSS Explained the } \\
\text { Differences Between } \\
\text { Secondary and Postsecondary } \\
\text { Legal Protections }\end{array}$ & 1.69 & 2.32 & 0.930 & 1.093 \\
\hline $\begin{array}{l}\text { High School Explained the } \\
\text { Differences Between } \\
\text { Secondary and Postsecondary } \\
\text { Legal Protections }\end{array}$ & 1.44 & 1.82 & 0.902 & 1.086 \\
\hline
\end{tabular}

Legal Rights Awareness. Respondents were asked awareness questions regarding protections provided to students with disabilities under federal law. Students were first asked if they have an awareness of the American with Disabilities Act (ADA) as is pertains to their rights as a student. A rating scale was used to determine the strength of student understanding of their rights under ADA. Students selected one of the following: (1) strongly disagree, (2) disagree, (3) agree, (4) strongly agree.

The first statement students were asked to rate was: The American with Disabilities Act (ADA) protects my rights as a college student with a disability. The mean rating of this 
question was 3.36 with an SD of 0.745 . Fifty-percent of respondents strongly agreed and 37\% percent agreed that the ADA protects their rights as a college student with a disability. Eleven percent of students disagreed and $2 \%$ strongly disagreed that they are protected under ADA. A chi-square test of independence was completed using this variable and the variable I have a strong understanding of my legal rights as a student with a disability. A strong association ( $\phi$ $=0.608)$ was found between respondents' rating of the two variables, $X^{2}(9, N=113)=41.817$, $p>0.5$. Students who strongly agreed they have an understanding of their legal rights were also more likely to strongly agree ADA protects them as a student with a disability.

The next statement was meant to ascertain student awareness levels of the transition of legal protection from the Individuals with Disabilities Education Act (IDEA) in high school to ADA in college. The survey item again asked for students to rate their agreement to the following statement: The Individuals with Disabilities Education Act (IDEA) 2004 protects my rights as a student with a disability. Students rated their response based on the following scale: (1) strongly disagree, (2) disagree, (3) agree, (4) strongly agree. The mean response was 3.27 with an SD of 0.824 . Forty-seven percent of respondents strongly agreed and $36 \%$ of respondents agreed that IDEA protects college students with disabilities. Thirteen percent disagreed and $4 \%$ strongly disagreed with the IDEA statement. A chi-square test of independence was completed to ascertain a relationship between this variable and the variable I have a strong understanding of my legal rights as a student with a disability. The negative hypothesis was accepted as there was a strong association $(\phi=0.636)$ found between the two variables, $\mathrm{X}^{2}(9, \mathrm{~N}=113)=45.714, p>0.5$. Students who strongly agreed they understood their legal rights were also more likely to strongly agree IDEA protects their rights as a student with a disability. 
On the same topic of student awareness of legal rights was a series of questions designed to determine if students understand personal obligations under ADA. The first question asked if students were aware of their responsibilities to coordinate accommodations. Students rated their response based on the following scale: (1) strongly disagree, (2) disagree, (3) agree, (4) strongly agree. The mean response was 3.15, SD 0.759. Thirty-five percent of respondents strongly agreed and $46 \%$ of respondents agreed that accommodation coordination is the responsibility of the student. Seventeen percent disagreed and $2 \%$ strongly disagreed that accommodation coordination is the responsibility of the student.

The next question in this series asked if participants were aware of the responsibility the postsecondary institution bears to coordinate accommodations. Students rated their response based on the following scale: (1) strongly disagree, (2) disagree, (3) agree, (4) strongly agree. The mean response was $2.87, S D 0.921$. Twenty-eight percent of participants strongly agreed and $38 \%$ of participants agreed that accommodations are the responsibility of the college to coordinate. Twenty-six percent disagreed and $8 \%$ strongly disagreed that accommodation coordination is the responsibility of the college.

\section{Student Understanding of Documentation Requirements and Accommodations}

Process. Respondents were queried of their awareness of documentation requirements and the accommodation approval process for their specific college. Students rated their response based on the following scale: (1) strongly disagree, (2) disagree, (3) agree, (4) strongly agree. The mean of the first statement, I am clear on the documentation requirements to receive accommodations at this college, was $3.32, S D$ 0.811. Fifty percent of respondents strongly agreed and 35\% agreed that they were clear on documentation requirements for their college. Eleven percent disagreed and $4 \%$ strongly disagreed with the same statement. 
The mean of the second statement: I am clear on the process to receive academic support services at this college was 3.35, SD 0.790. Fifty-two percent of participants strongly agreed and 34\% agreed they were clear on the process to receive services. Twelve percent disagreed and 3\% strongly disagreed that they understood the process to receive academic supports at their college.

\section{Research Question 3. Confidence of Postsecondary Students Using Self-Advocacy Skills}

Descriptive data were analyzed combining both the public and private institution to get data on the overall experience for students in four-year settings. The research question was not specific to experiences at either a public or private institution, so no disaggregation was made in the data. This section discusses the descriptive analyses for each variable pertaining to self-advocacy skills.

Respondents were asked a series of questions regarding confidence levels and the use of self-advocacy skills in college. The first item asked students to rate the statement $I \mathrm{am}$ confident using self-advocacy skills in college. Students rated their response based on the following scale: (1) strongly disagree, (2) disagree, (3) agree, (4) strongly agree. The mean for this statement was $3.07(S D=0.933)$. Forty-one percent of students strongly agreed and $32 \%$ agreed with the statement regarding confidence and self-advocacy skills. Twenty-one percent of students disagreed and $6 \%$ of students strongly disagreed they are confident using selfadvocacy skills in college.

Academic Decision-Making. Another set of items included in the self-advocacy confidence section of the survey asked students about their patterns of academic decisionmaking. The first item asked if students were comfortable making academic decisions without consulting others. Eighty-percent of students responded yes, they are confident making 
academic decisions without consulting others and $20 \%$ responded $n o$, they are not confident making academic decisions without consulting others.

Respondents were then asked whom they consult about their learning needs.

Respondents were given a list of possible people they would consult with and were asked to rate each option. Students rated their responses based on the following scale: (1) strongly disagree, (2) disagree, (3) agree, (4) strongly agree.

I consult Academic Support Services. The mean for this response was $2.90(S D=$ 1.017). Thirty-three percent of participants strongly agreed and $29 \%$ agreed with this statement. Fourteen percent of respondents disagreed and another 14\% strongly disagreed with the statement that they consult DSS regarding academic decisions.

I consult my parents. The mean for parent consultation was 2.71 with an SD of 1.237. Forty-one percent of students strongly agreed and $14 \%$ agreed with this statement. Twentypercent of respondents disagreed and $25 \%$ strongly disagreed they consult their parents regarding academic decisions.

I consult my friends. The mean for this statement was $2.19(S D=1.065)$. Fifteen percent of students strongly agreed and $22 \%$ agreed they consult with friends regarding academic decisions. Twenty-nine percent of respondents disagreed and $34 \%$ strongly disagreed with this statement.

I consult my academic advisor. The mean response for this statement was 2.38 with an SD of 1.144. Twenty-four percent of students strongly agreed and 20\% agreed with this statement. Twenty-seven percent of respondents disagreed and 29\% strongly disagreed with the statement they consult their academic advisor regarding academic decisions.

I consult my personal therapist or counselor. With a mean of $2.27(S D=1.170), 21 \%$ 
of students strongly agreed and $21 \%$ agreed they consult with a therapist or counselor on academic decisions. Twenty-one percent disagreed and 37\% strongly disagreed they consult a personal therapist or counselor for academic decision.

I consult with "other". The mean response for this statement was 1.60 with an SD of 1.031. Nine percent of students strongly agreed and $14 \%$ agreed with this statement. Five percent disagreed and $72 \%$ strongly disagreed they consult others for academic decision assistance. Respondents who selected agree or strongly agree were then prompted to use a text box to report whom they have consulted. Responses for other included: acupuncturist, other family members, employers, doctors, and other faculty.

Confidence factors for students with disabilities at four-year colleges. The last series of questions about self-advocacy confidence levels pertained to a series of confidence factors such as: speaking to others about learning needs, feeling in control of accommodations, understanding of legal rights, and if the students feels they would benefit from self-advocacy skills training. Students rated their responses based on the following scale: (1) strongly disagree, (2) disagree, (3) agree, (4) strongly agree.

\section{I feel confident speaking with faculty members regarding my specific learning}

needs. The mean for this statement was 3.07 with an SD of 1.015. Forty-three percent of participants strongly agreed and $32 \%$ agreed they are comfortable speaking with faculty members regarding their learning needs. Thirteen percent of respondents disagreed and $12 \%$ strongly disagreed with this statement.

I feel confident speaking with other students either in-class or outside of class about my specific learning needs. The mean response for this statement was $2.51(S D=1.119)$. Twenty-seven percent of respondents strongly agreed and $21 \%$ agreed with this statement. 
Twenty-nine percent disagreed and $23 \%$ strongly disagreed they are confident speaking with other students regarding their learning needs.

I feel confident speaking with friends about my specific learning needs. With a mean of 2.94 ( $S D=1.051), 39 \%$ of students strongly agreed and $28 \%$ of students agreed they are confident speaking with friends about their learning needs. Twenty-one percent disagreed and $13 \%$ strongly disagreed with the same statement.

I feel in control of decisions regarding my accommodation needs. The mean for this statement was $3.14(S D=0.905)$. Forty-four percent of students strongly agreed and $30 \%$ agreed they feel in control of decisions regarding their accommodation needs. Twenty-one percent disagreed and $4 \%$ strongly disagreed with the same statement.

I feel I have a strong understanding of my legal rights as a student with a disability or attention disorder. The mean response of this statement was 2.88 with an SD of 0.965 . Thirty-one percent of students strongly agreed and 35\% agreed with this statement. Twentyfour percent of respondents disagreed and 10 percent strongly disagreed they have an understanding of their legal rights as a student with a disability.

I think I would benefit from self-advocacy skills training. The mean of this statement was $2.69(S D=1.027)$. Twenty-five percent of students strongly agreed and $36 \%$ agreed they would benefit from self-advocacy skills training. Twenty-two percent of respondents disagreed and $17 \%$ strongly disagreed with the same statement.

\section{Research Question 4. Self-advocacy awareness and confidence levels influence on disclosure patterns for college students with disabilities}

Several dimensions were analyzed to study awareness and confidence levels and how they relate to disclosure. As a first step in the analysis, descriptive statistics (i.e., measures of 
central tendency, variability, and distribution) were calculated. To determine the relationship between non-dichotomous variables of interest and self-advocacy skills awareness or confidence, a chi-square test of independence was calculated. In instances in which the null hypothesis was rejected, a post-hoc phi test was calculated to determine the strength of the association between variables. What follows is a discussion of descriptive and analytic results for each of the dimensions of interest.

Whom students chose to identify to at their college. Data were analyzed to look for relationships between the dichotomous variables: identification to DSS, faculty, academic advisor, other students, or other support staff and the categorical variables of awareness and then confidence of self-advocacy skills. Students were asked to respond yes or no to a list of people they may have identified their learning needs to on their campus. Students were later asked to rate the following statements: I am aware of the self-advocacy skills needed to be successful in college and I am confident using self-advocacy skills in college using the scale: (1) strongly disagree, (2) disagree, (3) agree, or (4) strongly agree. Descriptive data and chisquare tests of independence were analyzed for each set of variables and are included in Tables 16 and 17. 


\section{Table 16}

Descriptive and Associative Analyses of Student Awareness of Self-Advocacy Skills Rating and Whom Students Have Identified to at Their College

\begin{tabular}{|c|c|c|c|c|}
\hline \multirow[b]{2}{*}{ Whom Student Has Identified To } & \multicolumn{2}{|c|}{$\frac{\text { Awareness of Self- }}{\text { Advocacy Skills }}$} & \multirow[b]{2}{*}{$X^{2}$} & \multirow[b]{2}{*}{$\phi$} \\
\hline & $M$ & $S D$ & & \\
\hline DSS & 3.34 & 0.920 & 11.147 & 0.315 \\
\hline Faculty & 3.36 & 0.923 & 11.659 & 0.321 \\
\hline Academic Advisor & 3.41 & 0.938 & 6.406 & \\
\hline Other Students & 3.33 & 0.899 & 1.386 & \\
\hline Other Support Staff & 3.39 & 0.868 & 0.660 & \\
\hline
\end{tabular}

Note. $p>0.05$

The null hypothesis was accepted for the independent variable of self-advocacy awareness and the following dependent variables: identification to academic advisor, identification to other students, and identification to support staff. There was no relationship found between these dependent and independent variables. A moderate relationship was found between self-advocacy awareness and identification to DSS. Another moderate relationship was found between self-advocacy awareness and identification to a faculty member. 


\section{Table 17}

Descriptive and Associative Analyses of Student Confidence Using Self-Advocacy Skills Rating and Whom Students Have Identified to at Their College

\begin{tabular}{|c|c|c|c|c|}
\hline \multirow[b]{2}{*}{ Whom Student Has Identified To } & \multicolumn{2}{|c|}{$\frac{\text { Confidence Using }}{\text { Self-Advocacy Skills }}$} & \multirow{2}{*}{$\underline{\mathrm{s}} \mathrm{X}^{2}$} & \multirow[b]{2}{*}{$\phi$} \\
\hline & $M$ & $S D$ & & \\
\hline DSS & 3.12 & 0.930 & 13.112 & 0.235 \\
\hline Faculty & 3.12 & 0.930 & 3.335 & 0.321 \\
\hline Academic Advisor & 3.25 & 0.869 & 6.263 & \\
\hline Other Students & 3.10 & 0.878 & 4.177 & \\
\hline Other Support Staff & 3.27 & 0.872 & 3.806 & \\
\hline
\end{tabular}

Note. $p>0.05$

The null hypothesis was accepted for the independent variable of self-advocacy confidence and the dependent variables of identification to: faculty, other students, and other support staff. The null hypothesis was rejected for the dependent variable of identification to DSS and the dependent variable of academic advisor. A moderate relationship was found between a student identifying their learning needs to the office of academic support and their self-advocacy confidence. A moderate relationship was also found between a student identifying their learning needs to an academic advisor and their self-advocacy confidence. 


\section{Chapter 5: Background, Discussion, and Recommendations}

\section{Background}

The purposes of this dissertation study were to analyze the relationships among undergraduate student perceptions, self-advocacy awareness and confidence, and available disability accommodations at two institutions of higher learning. Quantitative data were analyzed from one public and one private university in order to form comparative sets of data.

The analyses were based on the hypothesis that students with disabilities still face challenges accessing four-year postsecondary education. It was assumed that students with disabilities arrive at college with poor knowledge of their disability, their legal rights, their learning needs, and self-advocacy skills due to the dependency model of special education services in elementary and secondary settings (Brinckerhoff, Shaw, \& McGuire, 1992;

Cawthorn \& Cole, 2010; Shaw \& Dukes, 2006). It was also supposed students attempt to not disclose their disability until they begin to struggle and are uncomfortable discussing their learning needs with faculty. In terms of accommodations, the hypothesis was that colleges continue to offer students with disabilities a generalized menu of services that meet disability categories, not individual student needs. Self-advocacy skills training was presumed to not be consistently available to undergraduate students with disabilities. Analyses of the data collected for this dissertation study supported these hypotheses.

This study is important to the field of special education for several reasons. The research questions posed in this study addressed gaps in the current body of literature. New research in this area is imperative to help students with disabilities experience more success in postsecondary settings. As the number of students with disabilities who choose four-year postsecondary education continues to rise, universities are going to have to address the 
diverse learning needs of this population. It is vital to add current, student-centered data about academic supports, self-advocacy experiences, and the transition needs of students to the knowledge base on postsecondary education for students with disabilities. This chapter introduces the implications of the findings and conclusions followed by recommendations for future research.

\section{Discussion}

The findings for each of the research questions are included along with conclusions and possible implications for the field of postsecondary special education.

\section{Research Question 1: Public and Private Student Comparative Experiences with}

\section{Academic Supports}

The sample population of undergraduate students with disabilities appear to have similar experiences attending college. In both settings, public and private, students have similar identification patterns, accommodation experiences, and support experiences. It was expected that students at the private university feel more supported, being at a smaller, more individualized institution, but this proved to not be the case. Students at the public university feel just as supported, which may speak to the greater support resources and personnel that are available at a larger institution. Other findings of note are detailed in the following subsections.

Identification patterns. Analysis revealed that more public college students disclosed to others in all categories (DSS, faculty, advisor, and/or other support staff) than private school students. While there was no significance found from the associative analysis between school of attendance and disclosure, a few possible hypotheses can be drawn from these data based on descriptive analyses. Public college students, on average, are older than their private 
school counterparts (28 years old compared to 23 years old). One hypothesis may be that older students are more comfortable discussing their learning needs with other campus contacts beside DSS. Another possible theory is that the public school is a larger institution and students feel they bear a larger responsibility for their own learning needs. At a private college, students may expect that the smaller environment lends itself to Disability Support Services (DSS) handling all their support needs.

The causes of identification were the next dimension analyzed and has noteworthy implications. No significant relationship was found between school of attendance and why a student chose to identify. The largest number of students of the total sample (38\%) reported they disclosed their disability after struggling in a class. This average was higher for public school students $(42 \%)$ and lower for private school students $(30 \%)$ when the data were disaggregated. A possible theory is that public school students, more comfortable speaking with faculty about their disability because of their age, seek help out on their own. Students at the private school (41\%) identified in greater numbers at application than their public counterparts $(28 \%)$. One possible conclusion is that students applying to a private school believe disclosing a disability and the challenges they have experienced may make them a more appealing candidate to a highly selective application committee (Skinner, 2004).

Accommodations utilized. Several accommodations were found to have significant relationships with school of attendance. Students attending a public university are more likely to utilize registration assistance. One theory is that being at a larger institution, public school students may rely on this accommodation more frequently so they can get into the classes they require to graduate. Students at the public university are also more likely to use peer tutoring and specialized computer lab access. Upon further analysis, it was found that peer tutoring 
and computer lab access is offered through DSS at the public university, but not at the private university. Peer tutoring at the private university is available as a general service to all students. There are no accommodations made at the private university for extended computer lab access or specialized technology access beyond what is offered to all students. The next accommodation that showed a significant relationship was alternative text formats and public school attendance. A hypothesis that could be made, based on the size and services offered at each college, that the public university respondents may have greater access to a library of alternative texts. In terms of adaptive technology, students at the public university are more likely to use this accommodation than their private school counterparts. Again, this may be due to the larger size of the university allowing for more available resources.

The next significant relationship found was public school attendance and captioning and sign language interpretation. This relationship is likely because, while there was a very small percentage students who reported being Deaf $(1.3 \%$ at the public university and $2.9 \%$ at the private university), no students at the private university and $2.5 \%$ of the public college students reported having a hearing impairment. The total overall percentage of students who were either Deaf or had a hearing impairment at the public college was $3.8 \%$, compared to $2.9 \%$ at the private university. One possible theory is the relationship between school of attendance and use of captioning and sign language interpretation may exist because more students at the public institution have the need for these accommodations. Also of note was that the data discussed in the next section that shows students did not find either of these accommodations useful. This opinion may also have an impact on students choosing to use these accommodations. 
Usefulness of accommodations. While no significant relationships were found between the perceived usefulness of accommodations and school of attendance, there were some interesting results from this set of data. Students at both schools feel that the following accommodations are useful or very useful: alternative exams, documentation sent to professor on behalf of student, and registration assistance. This finding departs from earlier research showing students found note takers, proofreaders, and testing accommodations to be the most useful accommodations (Finn, 1998; Mellard \& Kurth, 2006). Public school students also reported advising and voice recording as useful. Of particular note was that of the comprehensive list of 24 accommodations students had utilized, students rated the remaining 19 accommodations as not useful or not useful at all (e.g., note takers, proofreaders, sign language interpretation, substitute coursework, transcription services, and captioning services). This speaks to a serious need to research the effectiveness and update accommodation service offerings for postsecondary students with disabilities. This is especially true in light of recent technological advances that may have rendered certain accommodations, such as note takers, proofreaders, and transcription, obsolete.

Student support experiences. The first significant results in this section pertained to student satisfaction with the academic support office at their college. The mean of the entire sample was satisfied to very satisfied with all the personnel aspects of their DSS office. The satisfaction ratings match current research pertaining to successful academic support offices. Successful offices employ professionals who specialize in supporting adults with disabilities, knowledge and methods around a core set of adult developmental principles (Brinckerhoff, McGuire, \& Shaw, 2002). These students feel their DSS communicates well, is efficient and approachable, helpful, knowledgeable, and respectful. The sample reports satisfaction with 
the documentation requirements and process at their college. They feel satisfied with the disability knowledge level of staff, the academic program knowledge, and knowledge of other supports. Students also report being satisfied with disability education programs that are offered through their DSS. This may support current research that shows colleges are looking at students as consumers who are entitled to effective education and tailoring their support programs to meet this view (Mellard \& Kurth, 2006).

When asked what services are currently offered and what students would like to see offered, some noteworthy data were collected. An associative relationship was found between public university attendance and self-advocacy training. While 39\% of public school respondents reported self-advocacy training being offered on their campus, only $5.9 \%$ of private school attendees reported their school offers self-advocacy training. Public school students want community building, social media connections, and mentoring with older students with disabilities. In theory, this may speak to the size of the institution. Students at a larger, more commuter-based university may want additional personal connections than those at the smaller, private institution, who might already feel connected to their university.

\section{Research Question 2. Postsecondary Student Knowledge Regarding Self-}

\section{Advocacy Skills}

Students with disabilities believe they are aware of self-advocacy skills. They also believe they understand the legal protections offered to them by the federal government. However, further analyses revealed that while these students believe they understand selfadvocacy and their legal rights, they have a very weak knowledge base of disability, transition, and accommodations. They have very poor transition experiences from secondary to postsecondary education. Overall, participants had not sought out any disability education. 
Students do not feel that disability knowledge will help them find success in postsecondary settings. If they are lacking disability knowledge, they may be unable to effectively advocate for themselves in the classroom. These findings match previous research on student knowledge of disability, accommodations, and transition (Cawthorn \& Cole, 2010; Lindstrom, 2007; Nelson, Smith, Appleton, \& Raver, 1993).

Also of note is when the sample population was diagnosed with a disability. Thirty-six percent of public and $79 \%$ of private university students report receiving special education services in high school. This creates a gap of students who were identified with a disability in college and would have missed any available transition services (including disability knowledge and legal education) from secondary to postsecondary education. This is a gap that needs to be addressed by postsecondary settings to assist these students with disability and legal education, self-advocacy skills training, and also meet potential needs for emotional support. Other findings of interest are detailed in the following sections.

Self-advocacy skills. Undergraduate students with disabilities who participated in this survey feel they are aware of effective self-advocacy skills. However, they strongly disagree they have had self-advocacy skills training. Only $17 \%$ report having any such training in high school and 29\% report having some self-advocacy skills training in college. Programs such as Project Eye to Eye (http://www.eyetoeyenational.org) need to be expanded in elementary and into secondary schools to teach students with disabilities much needed self-advocacy skills. This program pairs college students with disabilities with elementary students with learning disabilities and/or ADD/HD. The goal of the program is empowering students through increased self-esteem, self-awareness, and self-advocacy skills. Similar programs should also 
be created at the postsecondary level to assist students who are identified with disabilities after secondary school.

The sample agrees with Skinner's (2004) successful student factors with a few exceptions. Students disagree that participating in non-academic campus activities makes them more successful in college. While data were not disaggregated by school of attendance, the hypothesis could be this result may be due to a larger number of respondents being older and attending a public, commuter-based university. These students are less likely to participate in activities on campus (Svanum \& Bigatti, 2009). Respondents also disagree with the statement that reading about other students with disabilities makes them successful in postsecondary education. One hypothesis could be this result speaks to the highly individualized nature of disability and students not wanting to be defined by a disability category. Participants also do not feel that it is necessary to review their most recent assessment(s). This finding shows that students may not be aware of the importance of understanding their own strengths and weaknesses in relation to their academic achievement which correlates with previous research in this area (Cole \& Cawthorn, 2010; Lindstrom, 2007; Nelson, Smith, Appleton, \& Raver, 1993).

Legal and transition education. One of the most interesting findings for this set of data was past legal and transition education. Students overwhelmingly are coming to college unprepared for the transition as well as knowledge of their legal rights and obligations. This finding matched previous research on transition experiences as well (Brinckerhoff, McGuire, \& Shaw, 2002; Connor, 2012; Gregg, 2007). Students strongly disagree they had a transition plan relating to a four-year college. The sample also strongly disagrees their high school prepared them well for the transition to a four-year college. In addition, participants strongly 
disagree their high school and college had explained the differences between secondary and postsecondary legal protections for students with disabilities, most importantly the ADA and the Individuals with Disabilities Education Act (IDEA).

Students were also asked about their protections under ADA and IDEA. The sample population strongly agree that both federal laws protect them as postsecondary students with disabilities. After further analysis, it was determined there was a strong association between students believing they have a strong understanding of their legal rights and their belief that the ADA protects them as students with disabilities. It was also determined that a strong relationship existed between students believing they have a strong understanding of their legal rights and their belief that IDEA protects them as students with disabilities. "Whereas the documentation under IDEA 2004 is based on a philosophy of entitlement to education, the documentation under Section 504 and ADA is based on the philosophy of access, a subtly nuanced, but critical difference" (Lindstrom \& Tuckwiller, 2008, p. 103). Since IDEA only protects students through secondary school, it is apparent that while students believe they understand their rights, they clearly do not based on their responses.

Accommodation knowledge. The last key finding about legal protections pertains to responsibility for accommodations. Participants report they do understand their own responsibility for coordination of accommodations, but do not understand the responsibility and requirements their institution has to coordinate accommodations on their behalf. This again speaks to the lack of knowledge postsecondary students have about the rights of people with disabilities. 


\section{Research Question 3. Confidence of Postsecondary Students Using Self-Advocacy Skills}

Participants report confidence using self-advocacy skills. In terms of academic decision-making, students do not feel they need to consult others and are comfortable being in control of academic and accommodation decisions. Students report they are comfortable speaking with faculty members regarding their learning needs. Students disagree they have a strong understanding of their legal rights as a student with a disability; however, respondents report they do not feel a need to have self-advocacy skills training which would include legal education.

There were contradictions in this set of findings when compared to the findings for the previous research question on self-advocacy awareness. Students appear to have confidence in themselves using self-advocacy skills, but do not have the practical knowledge, such as knowing their legal rights and disability knowledge, to accurately have confidence in their actions. For example, $66 \%$ of respondents agreed or strongly agreed they had a strong understanding of their legal rights. However, $83 \%$ of respondents also agreed or strongly agreed that IDEA protects them as a postsecondary student with a disability. In addition, respondents report not being comfortable discussing their learning needs with anyone other than college faculty.

Students state they have poor self-advocacy skills training and disability knowledge education, but feel they are strong advocates for their own learning needs. Only $17 \%$ of students report receiving self-advocacy skills training in high school and 28\% report receiving self-advocacy skills training in college. Sixty-one percent of respondents report they would benefit from self-advocacy skills training. At the same time, $73 \%$ of participants agree or 
strongly agree they are confident using self-advocacy skills. These contradictions highlight a critical area of concern for postsecondary students with disabilities.

\section{Research Question 4. Self-advocacy awareness and confidence levels influence on}

\section{disclosure patterns for college students with disabilities}

When looking at self-advocacy awareness, confidence, and identification patterns, there were several associations of note. Participants that report being aware of self-advocacy skills are more likely to identify to DSS and faculty. A possible theory may be that students who are aware of self-advocacy skills know that the support office is the best route for receiving the support and accommodations they need. In addition, these respondents may be able to articulate their needs better directly to faculty members. Students who report being confident using self-advocacy skills are more likely to identify to DSS and their academic advisor. This again, in theory, may be because these students are able to articulate their needs and rights in a confident manner. Identifying to their academic advisor may signal that these students are confident expressing their needs and understanding the need to find how those needs fit into their overall academic program. The concern that arises from this information is these students feel aware and confident using self-advocacy skills, but do not have the disability or advocacy knowledge to support those beliefs. In reality, they may be shortchanging themselves academically.

\section{Limitations}

There were several limitations present in this dissertation study. The greatest weaknesses in this study were sample size and response rate. The sample included only two colleges with 113 respondents from those two universities. The total response rate was $10 \%$. Generalizing from data collected through this research is not possible due to the convenience 
and small size of the sample of students surveyed. In addition, there could be differences between the target population of undergraduate students with disabilities and the accessed sample. Only students with disabilities who had identified themselves to their academic support office were included, excluding students at the universities who had chosen not to identify. This could have produced over or under representation of transition experiences for this particular sample of students with disabilities.

There were also limitations present in the collection of data. The survey instrument was a limitation in that it was an online survey. This may have excluded potential respondents who did not have the necessary computer skills, access to the Internet, or a computer. The survey was created to be as understandable and as impartial as possible, but there is the potential that there were unclear or biased items that would have affected the outcome of responses. The last limitation is the nature of participants' self-reporting. There is no manner to ensure that respondents answered each item honestly and to the best of their ability.

\section{Recommendations for Secondary Settings}

Overwhelmingly, students in this study reported poor transition experiences from high school to four-year postsecondary settings. It is imperative that secondary settings create more effective transition plans that include college-ready as a purposive goal option. Federal law requires students in special education to have a transition component of their individual education plan (IEP) in place by age 16; however, these are often not as comprehensive as they could be in regards to college attendance. College selection and comparisons of support services should be deliberate and included in a student's transition plan in high school. It is also recommended that secondary settings seek out knowledge and connections with postsecondary institutions to match students with postsecondary supports and services before 
they enroll in college, such as the HEATH Center at George Washington University (http://www.heath.gwu.edu).

Current research demonstrates the importance of self-advocacy skills training. Students who participated in this study had very little self-advocacy skills training in secondary school. Explicit instruction in self-advocacy skills needs to be a priority for these students, early and consistently. The importance of teaching self-advocacy skills to secondary students with disabilities who struggle as a part of typical adolescent development to find their own identities, become independent, and grow into self-awareness cannot be understated. These skills are critical to not only postsecondary success, but success across the lifespan. One key aspect of self-advocacy is disability knowledge (Skinner, 2004). Disability self-awareness education must be an ongoing part of the secondary support system for students with disabilities. Students need to have a clear understanding of their disability so that they may articulate their needs effectively in college. This will also help the accommodations process be successful when a student knows what supports may best assist him in college.

\section{Recommendations for Postsecondary Settings}

Students in the study reported they found very few accommodations useful. Colleges need to review the effectiveness of accommodations and services provided by academic support offices. Current students with disabilities need and expect varied and specialized services. The results of this study also demonstrated very few self-advocacy training experiences for participants. Postsecondary settings should begin to provide self-advocacy skills training for students with disabilities. Students need further information on their legal protections, obligations, and disability education in addition to being able to advocate effectively for themselves. This is critical to ensuring these students are successful in college and beyond. 
There were quite a few students who participated in the survey who were not diagnosed with a disability until after secondary school. Further planning for students who acquire disabilities while in college needs to be a priority. These students pose distinctive challenges in that they have no history of services, have missed any available transition service opportunities, and may need increased emotional support in addition to academic support.

\section{Recommendations for Future Research}

The results of this study indicate students feel confident with their level of self-advocacy knowledge. Self-advocacy confidence levels and retention/success rates of undergraduate students with disabilities is an area for future research. How does confidence influence retention? What are the implications for students who profess confidence without having the disability and self-advocacy knowledge which research shows produces successful outcomes?

There were several variables in this study that deserve further exploration but due to study scope and time constraints were only discussed briefly. Transition plans need to be studied in a more comprehensive manner. How these services are planned, coordinated between secondary and postsecondary settings, and how information is disseminated deserves study to ensure that all students understand the shift in services from one setting to the next. Another variable of this study that was only discussed briefly were disclosure patterns. Disclosure and non-disclosure patterns and motivations are other areas for future research. Such studies would not only add to the knowledge base in terms of the psychology of students with disabilities, but could connect with many other areas of future research as well, such as campus climate, accommodations, and services. The effectiveness of accommodations also needs to be studied on a large scale. Accommodations currently offered at colleges were created decades ago for a very different set of students with disabilities (e.g. transcription). 
Today, the demographic of students with disabilities looks very different and a review of available services is critical to making sure students are supported. Students expect a more specialized interaction with academic supports and do not see most accommodations as effective.

Current literature shows there is a need for expanded national data to be collected for students with disabilities. Current data are collected only from parents whose children received special education services in high school through longitudinal transition studies and colleges using the Postsecondary Education Quick Information System (PEQIS). These data exclude students who are identified with a disability after high school and have chosen not to identify to their college. As a growing demographic of students, researchers need comprehensive, student-centered data sets that show national trends over time for a variety of dimensions such as retention, disclosure patterns, employment outcomes, graduate school attendance, and time to graduation rates. 


\section{References}

American Psychological Association. (2010). Publication manual of the American Psychological Association (6th ed.). Washington, DC: Author.

American with Disabilities Act of 1990. PL No. 104-327. Retrieved from http://www.ada.gov/statute.html

American with Disabilities Amendments Act of 2008. PL No. 110-325. Retrieved from http://www.ada.gov/pubs/ada.htm

Association on Higher Education and Disability (AHEAD). (2011). Advising students with disabilities. Huntersville, NC: Author.

Astin, A. W. (1993). What matters in college. Liberal Education, 79(4), 4-17.

Baggett, D. (1994, March). A study of faculty awareness of students with disabilities. Paper presented at the annual conference of the National Association for Developmental Education, Kansas City, MO.

Berkner, L., Cuccaro-Alamin, S., McCormick, A., \& Bobbit, L. G. (1996). Descriptive summary of the 1989-90 beginning postsecondary students: 5 years later with an essay on postsecondary persistence and attainment (NCES 1996-1555). United States Department of Education, National Center for Education Statistics. Washington, DC: U.S. Government Printing Office.

Brinckerhoff, L. C., McGuire, J. M., \& Shaw, S. F. (2002). Postsecondary education and transition for students with learning disabilities. Austin, TX: Pro-Ed.

Brinckerhoff, L. C., Shaw, S. F., \& McGuire, J. M. (1992). Promoting access, accommodations, and independence for college students with learning disabilities. Journal of Learning Disabilities, 25(7), 417-429. 
Burgstahler, S., \& Moore, E. (2009). Making student services welcoming and accessible through accommodations and universal design. Journal of Postsecondary Education and Disability, 21(3), 155-174.

Carnevale, A. P., \& Desrochers, D. M. (2003). Preparing students for the knowledge economy: What school counselors need to know. Professional School Counseling, 6(4), 228-236.

Cawthorn, S. W., \& Cole, E. V. (2010). Postsecondary students who have a learning disability: Student perspectives on accommodations access and obstacles. Journal of Postsecondary Education and Disability, 23(2), 112-128.

Center on Postsecondary Education and Disability. (2002). Postsecondary supports for students with disabilities. Storrs, CT: Shaw, S.

Connor, D. J. (2012). Helping students with disabilities transition to college. TEACHING Exceptional Children, 44(5), 16-25.

Costello, J. J., \& English, R. W. (2001). The psychosocial development of college students with and without learning disabilities. Journal of Postsecondary Education and Disability, 15(1), 16-27.

Council for Learning Disabilities. (n.d.). Reauthorization of the higher education act. Overland Park, KS: Author. Retrieved from http://www.cldinternational.org/Legislation/hea.asp

Crank, J. N., \& Deshler, D. D. (2001). Disability eligibility issues and university student assessment outcomes. Journal of Vocational Rehabilitation, 16, 217-226.

Cronk, B. C. (2010). How to use PASW statistics: A step-by-step guide to analysis and interpretation. Glendale, CA: Pyrczak Publishing. 
Deshler, D. D. (2005). Adolescents with learning disabilities: Unique challenges and reasons for hope. Learning Disabilities Quarterly, 28(2), 122-124.

DO-IT. (2013). The faculty room. Retrieved from http://www.washington.edu/doit/Faculty/

Education for All Handicapped Children Act, Pub. L. No. 94-142 (1975).

Embry, P. B., Parker, D. R., McGuire, J. M., \& Scott, S. S. (2005). Postsecondary disability service providers' perceptions about implementing universal design for instruction (UDI). Journal of Postsecondary Education and Disability, 18(1), 34-48.

Field, S., Hoffman, A., \& Posch, M. (1997). Self-determination during adolescence: A developmental perspective. Remedial and Special Education, 18(5), 285-293.

Finn, L. L. (1998). Students' perceptions of beneficial LD accommodations and services at the postsecondary level. Journal of Postsecondary Education and Disability, 13(1), 46-67.

Gerber, P. J., \& Reiff, H. B. (1991). Speaking for themselves: Ethnographic interviews with adults with learning disabilities (No. 9). University of Michigan Press.

Getzel, E. E. (2008). Addressing the persistence and retention of students with disabilities in higher education: Incorporating key strategies and supports on campus. Exceptionality, $16(4), 207-219$.

Gregg, N. (2007). Underserved and underprepared: Postsecondary learning disabilities. Learning Disabilities Research \& Practice, 22(4), 219-228.

Gregg, N., \& Nelson, J. M. (2012). Meta-Analysis on the effectiveness of extra time as a test accommodation for transitioning adolescents with learning disabilities: More questions than answers. Journal of Learning Disabilities, 45(2), 128-138. 
Hadley, W. M. (2007). The necessity of academic accommodations for first-year college students with learning disabilities. Journal of College Admission, 195, 9-13.

Healey, J. F. (2009). Statistics: A tool for social research. Belmont, CA: Wadsworth Cengage Learning.

HEATH Resource Center at the National Youth Transitions Center. (2011, July). Summer pre-college programs. Washington, DC: Author.

Henry, G. T. (1990). Practical Sampling. Newbury Park, CA: Sage Publishing.

Higher Education Act of 1965. PL No. 89-329. Retrieved from http://www.tgslc.org/pdf/HEA_Title_IV_Oct02.pdf

Higher Education Opportunity Act of 2008. PL No. 110-315. Retrieved from http://ifap.ed.gov/dpcletters/attachments/GEN0812FP0810AttachHEOADCL.pdf

Institute of Education Sciences. (2012). Retrieved from http://ies.ed.gov/

IRIS Center for Training Enhancements. (2009). Universal design for learning: Creating a learning environment that challenges and engages all students. Retrieved from http://www.iriscenter.com/udl/chalcycle.htm

Individuals with Disabilities Education Improvement Act of 2004. PL No. 108-446. Retrieved from http://nces.ed.gov/ipeds/datacenter/Default.aspx

Jensen, J. M., McCrary, N., Krampe, K., \& Cooper, J. (2004). Trying to do the right thing: Faculty attitudes towards accommodating students with learning disabilities. Journal of Postsecondary Education and Disability, 17(2), 81-90).

Johnson, G., Zascavage, V., \& Gerber, S. (2008). Junior college experiences and students with learning disabilities: Implications for success at the four-year university. College Student Journal, 42(4), 1162-1168. 
LD Online. (2004). An effective model for college students with learning disabilities and attention deficit hyperactivity disorders. Washington DC: Getzel, E. E., McManus, S., \& Briel, L. W.

Lindstrom, J. H. (2007). Determining appropriate accommodations for postsecondary students with reading and written expression disorders. Learning Disabilities Research \& Practice, 22(4), 229-236.

Lindstrom, J. H., \& Tuckwiller, E. D. (2008). Extended test time, read aloud, and student characteristics: A summary of empirical findings. Learning Disabilities, 15(3), 93104.

Litt, V., \& McGuire, J. M. (1989). Continuum of services. Storrs: The University of Connecticut Program for College Students with Learning Disabilities.

Mamiseishvili, K., \& Koch, L. C. (2011). First-to-second-year persistence of students with disabilities in postsecondary institutions in the United States. Rehabilitation Counseling Bulletin, 54(2), 93-105.

Manganello, R. E. (1992). Psychosocial problems among learning disabled college students. Research and Teaching in Developmental Education, 9(1), 67-78.

Mellard, D., \& Kurth, N. (2006). Student perceptions of the accommodation process in postsecondary education. Journal of Postsecondary Education and Disability, 19(1), 71-84.

Murray, C., Flannery, B. K., \& Wren, C. (2008). University staff members' attitudes and knowledge about learning disabilities and disability support services. Journal of Postsecondary Education and Disability, 21(2), 73-90. 
National Center for Education Statistics. (2012). College navigator. Retrieved from http://nces.ed.gov/collegenavigator/

National Center for the Study of Postsecondary Educational Supports (NCSPES). (2005). Supporting individuals with disabilities in postsecondary education. Honolulu, HI: Stodden, R. A., \& Conway, M. A.

National Center on Secondary Education and Transition (NCSET). (2004, February). An effective model for college students with learning disabilities and attention deficit hyperactivity disorders. Minneapolis, MN: Getzel, E. E., McManus, S., \& Briel, L. W.

Nelson, J. R., Smith, D. J., Appleton, V., \& Raver, K. (1993). Achievement-related beliefs of college students with disabilities. Journal on Postsecondary Education and Disability, $10(2), 9-20$.

O’Neill, L. N., Markward, M. J, \& French, J. P. (2012). Predictors of graduation among college students with disabilities. Journal of Postsecondary Education and Disability, $25(1), 21-36$.

Office for Civil Rights. (2011, September). Students with disabilities preparing for postsecondary education: Know your rights and responsibilities. Washington, DC: Author.

Orr, A. C., \& Hammig, S. B. (2009). Inclusive postsecondary strategies for teaching students with learning disabilities: A review of the literature. Learning Disability Quarterly, $32,181-196$.

PACER Center. (2003). ADA Q\&A...The ADA, Section $504 \&$ Postsecondary Education. Minneapolis, MN: Leuchovius, D. 
Paiz, J. M., Angeli, E., Wagner, J., Lawrick, E., Moore, K., Anderson, M., Soderland, L., Brizee, A., \& Keck, R. (2012, May 5). APA formatting and style guide: General format. Retrieved from http://owl.english.purdue.edu/owl/resource/560/01/

Palmer, C., \& Roessler, R. T. (2000). Requesting classroom accommodations: Self-advocacy and conflict resolution training for college students with disabilities. Journal of Rehabilitation, 66(3), 38-43.

Parker, D. R., \& Boutelle, K. (2009). Executive function coaching for college students with learning disabilities and ADHD: A new approach for fostering self-determination. Learning Disabilities Research \& Practice, 24(4), 204-215.

Post 9/11 Veterans Educational Assistance Act of 2008. PL No. 110-252. Retrieved from http://www.uscg.mil/hq/capemay/education/doc/38USCch33.pdf

Project Eye to Eye. (2013). Program model. Retrieved from http://eyetoeyenational.org/programs/our-programs.html

Raue, K., \& Lewis, L. (2011). Students with disabilities at degree-granting postsecondary institutions (NCES 2011-018). United States Department of Education, National Center for Education Statistics. Washington, DC: U.S. Government Printing Office.

Reed, M. J., Kennett, D. J., Lewis, T., Lund-Lucas, E., Stallberg, C., \& Newbold, I. L. (2009). The relative effects of university success courses and individualized interventions for students with learning disabilities. Higher Education Research and Development, 28(4), 385-400.

Ross, C. E., \& Mirowsky, J. (2011). The interaction of personal and parental education on health. Social Science and Medicine, 72(4), 591-599. 
Rush, T. A. (2011). "She's too smart to have ADHD”: Faculty willingness to accommodate students with ADHD at elite postsecondary institutions. (Doctoral dissertation). Retrieved from ProQuest. (AAI3455417)

Sanford, C., Newman, L., Wagner, M., Cameto, R., Knokey, A. M., \& Shaver, D. (2011). The post-high school outcomes of young adults with disabilities up to 6 years after high school. Key findings from the National Longitudinal Transition Study-2 [NLTS2] (SCSER 2011-3004). Menlo Park, CA: SRI International.

Svanum, S., \& Bigatti, S. M. (2009). Academic course engagement during one semester forecasts college success: Engaged students are more likely to earn a degree, do it faster, and do it better. Journal of College Student Development, 50(1), 120-132.

Schuck, J., \& Kroeger, S. (1993). Essential elements in effective service delivery. New Directions for Student Services, 64, 59-68.

Section 504 of the Rehabilitation Act of 1973. PL No. 93-112. Retrieved from http://nichcy.org/laws/section504

Section 504 compliance handbook. (1999). Washington, DC: Thompson.

Shaw, S. F., \& Dukes, L. L. (2006). Postsecondary disability program standards and performance indicators: Minimum essentials for the office for students with disabilities. Journal of Postsecondary Education and Disability, 19(1), 16-26.

Shepler, D. K., \& Woosley, S. A. (2012). Understanding the early integration experiences of college students with disabilities. Journal of Postsecondary Education and Disability, $25(1), 37-50$.

Sitlington, P. L., \& Frank, A. (1990). Are adolescents with learning disabilities successful crossing the bridge to adult life? Learning Disability Quarterly, 13, 97-111. 
Skinner, M. E. (2004). College students with learning disabilities speak out: What it takes to be successful in postsecondary education. Journal of Postsecondary Education and Disability, 17(2), 91-104.

Tinto, V. (1993). Leaving college: Rethinking the causes and cures of student attrition (2nd ed.). Chicago: The University of Chicago Press.

Trammell, J. (2009). Accommodations for multiple choice tests. Journal of Postsecondary Education and Disability, 24(3), 251-254.

Trammell, J., \& Hathaway, M. (2007). Help-seeking patterns in college students with disabilities. Journal of Postsecondary Education and Disability, 20(1), 5-15.

United States Department of Education (USDOE), Office of Special Education and Rehabilitative Services. (2010). Thirty-five years of progress in educating children with disabilities through IDEA. Retrieved from http://www2.ed.gov/about/offices/list/osers/idea35/history/idea-35-history.pdf

United States Department of Education (USDOE). (2011). Demonstration projects to ensure students with disabilities receive a quality higher education. Retrieved from http://www2.ed.gov/programs/disabilities/awards.html

United States Department of Education (USDOE), National Center for Education Statistics. (2012). The condition of education: Children and youth with disabilities Retrieved from http://nces.ed.gov/programs/coe/indicator_cwd.asp

United States Government Accountability Office. (2009). Higher education and disability: Education needs a coordinated approach to improve its assistance to schools in supporting students. (GAO-10-33). Retrieved from http://www.gao.gov/assets/300/297433.pdf 
Vogel, S. A., Holt, J. K., Sligar, S., \& Leake, E. (2008). Assessment of campus climate to enhance student success. Journal of Postsecondary Education and Disability, 21(1), $15-31$.

Wessel, R. D., Jones, J. A., Markle, L., \& Westfall, C. (2009). Retention and graduation of students with disabilities: Facilitating student success. Journal of Postsecondary Education and Disability, 21(3), 116-125.

Wilson, K., Getzel, E., \& Brown, T. (2000). Enhancing the postsecondary campus climate for students with disabilities. Journal of Vocational Rehabilitation, 14(1), 37-50.

Winston, R. B., Miller, T. K., \& Cooper, D. L. (1999). Student developmental task and lifestyle assessment. Athens, GA: Student Development Associates.

Wolniak, G. C., \& Pascarella, E. T. (2005). The effects of college major and job field congruence on job satisfaction. Journal of Vocational Behavior, 67(2), 233-251.

Zhang, D., Landmark, L., Reber, A., Hsu, H. Y., Kwok, O., \& Benz, M. (2010). University faculty knowledge, beliefs, and practices in providing reasonable accommodations to students with disabilities. Remedial and Special Education, 31(4), 276-286. 
Appendix A: Definition of Terms

Included below are definitions of specific vocabulary that appear frequently in this study:

\section{Accommodations}

An accommodation is a reasonable adjustment to teaching practices so that the student learns the same material, but in a format that is accessible to the student. Accommodations may be classified by whether they alter the presentation of material, the manner in which a student responds to information, the setting for presentation or assessment of material, or the scheduling of presentation or assessment of academic material.

\section{Disabilities}

Disability. For the purposes of this survey, disability is defined as: A mental or physical impairment, a record of impairment; and the impairment causes substantial limits in major life activities that include abilities such as (but not limited to) self-care, breathing, walking, seeing, performing schoolwork, speaking, and learning.

Attention disorders. Attention disorders, also referred to as Attention Deficit Hyperactivity Disorder (ADHD) or Attention Deficit Disorder (ADD), are defined as having a heightened alertness to environmental stimuli that results in limited alertness with respect to the educational environment, that - (a) is due to attention deficit disorder or attention deficit hyperactivity disorder; and (b) adversely affects educational performance.

Specific learning disability. For the purposes of this study, a specific learning disability (SLD or LD) is defined as: A disorder in one or more of the basic psychological processes involved in understanding or in using language, spoken or written, that may manifest itself in the imperfect ability to listen, think, speak, read, write, spell, or to do mathematical calculations, including conditions such as perceptual disabilities, brain injury, 
minimal brain dysfunction, dyslexia, and developmental aphasia. Specific learning disability does not include learning problems that are primarily the result of visual, hearing, or motor disabilities, of intellectual disability, of emotional disturbance, or of environmental, cultural, or economic disadvantage.

\section{Office of Disability Services, Academic Support Services, Disability Support Services}

Office of Disability Services, Academic Support Services, and Disability Support

Services all assist students with physical and learning disabilities with accommodations to help develop and enhance their student life skills as well as their academic needs. Upon receipt of a request for services and the appropriate documentation, Academic Support Services work with students to provide or establish the most suitable and reasonable accommodations or services. Postsecondary institutions are required to have a person or persons on staff for this purpose (GAO, 2009). For purposes of this study, Disability Support Services (DSS) was used as an operational definition.

\section{Postsecondary Education}

Higher or postsecondary refers to the stage of learning that occurs at universities, academies, colleges, seminaries, and institutes of technology. Postsecondary education also includes certain collegiate-level institutions, such as vocational schools, trade schools, and career colleges, that award academic degrees or professional certifications. For the purposes of this study, postsecondary education refers to four-year colleges. 


\section{Self-Advocacy}

Self-advocacy is the ability to recognize and meet the needs specific to one's disability or attention disorder. The critical elements of self-advocacy include: (1) disability knowledge, (2) an awareness of legal rights and responsibilities, (3) independent decision-making, and (4) the ability to competently express needs and rights to others. 
Appendix B: AHEAD Disability Support Program Standards and Performance Indicators

\section{AHEAD Program Standards and Performance Indicators}

The Association on Higher Education And Disability (AHEAD) is pleased to offer these revised Professional Standards and Performance Indicators to the field. The standards reflect the maturation of the postsecondary disability services profession, describe the breadth of skills and knowledge required of personnel administering the Office for Students with Disabilities (OSD), and present a consensus among experts in the field regarding minimum essential services. These standards are intended to enhance service provision for college students with disabilities by directing program evaluation and development efforts, improving personnel preparation and staff development, guiding the formulation of job descriptions for OSD personnel, informing judges and requisite court decisions regarding appropriate practice and, lastly, expanding the vision of disability services at the postsecondary level. 


\section{Consultation / Collaboration}

To facilitate equal access to postsecondary education for students with disabilities, the office that provides services to students with disabilities should:

1.1 Serve as an advocate for issues regarding students with disabilities to ensure equal access.

- Foster collaboration between disability services and administration as it relates to policy implementation.

- Ensure key administrators remain informed of emerging disability issues on campus that may warrant a new or revised policy.

- Foster a strong institutional commitment to collaboration on disability issues among key administrative personnel (e.g., deans, registrar, campus legal counsel).

- Work with facilities to foster campus awareness regarding physical access.

- Work collaboratively with academic affairs on policy regarding course substitutions.

- Foster an institutional commitment to promoting student abilities rather than a student's disability.

- Foster meaningful inclusion of students with disabilities in campus life (e.g., residential activities, extracurricular activities).

\subsection{Provide disability representation on relevant campus committees.}

- Advise campus student affairs regarding disability-related issues (e.g., student discipline, student activities).

- Participate on a campus-wide disability advisory committee consisting of faculty, students, administrators, and community representatives.

- Participate on campus administrative committees such as a campus committee on individuals with disabilities. 


\section{Information Dissemination}

To facilitate equal access to postsecondary education for students with disabilities, the office that provides services to students with disabilities should:

2.1 Disseminate information through institutional electronic and printed publications regarding disability services and how to access them.

- Distribute policy and procedures(s) on availability of services via all relevant campus publications (catalogs, programmatic materials, web sites, etc.).

- Ensure referral, documentation, and disability services information is up to date and accessible on the institution's web site.

- Ensure that criteria and procedures for accessing accommodations are clearly delineated and disseminated to the campus community.

- Ensure access to information about disabilities to students, administration, faculty, and service professionals.

- Provide information on grievance and complaint procedures when requested.

- Include a statement in the institutional publications regarding self-disclosure for students with disabilities.

\subsection{Provide services that promote access to the campus community.}

- Facilitate the acquisition and availability of a wide variety of assistive technology to help students access materials in alternative formats (e.g., JAWS for Windows screen reader, Kurzweil Voice Pro, Mountbatten Brailler).

- Provide information for the acquisition of computerized communication, text telephone (TT), or telecommunications devices (TDD) for the deaf.

- Promote universal design in facilities.

- Promote universal design in communication.

- Promote universal design in instruction.

\subsection{Disseminate information to students with disabilities regarding available campus and community disability resources.}

- Provide information and referrals to assist students in accessing campus resources. 


\section{Faculty / Staff Awareness}

To facilitate equal access to postsecondary education for students with disabilities, the office that provides services to students with disabilities should:

3.1 Inform faculty regarding academic accommodations, compliance with legal responsibilities, as well as instructional, programmatic, and curriculum modifications.

- Inform faculty of their rights and responsibilities to ensure equal educational access.

- Inform faculty of the procedures that students with disabilities must follow in arranging for accommodations.

- Collaborate with faculty on accommodation decisions when there is a potential for a fundamental alteration of an academic requirement.

\subsection{Provide consultation with administrators regarding academic} accommodations, compliance with legal responsibilities, as well as instructional, programmatic, physical, and curriculum modifications.

- Foster administrative understanding of the impact of disabilities on students.

3.3 Provide disability awareness training for campus constituencies such as faculty, staff, and administrators.

- Provide staff development regarding understanding of policies and practices that apply to students with disabilities in postsecondary settings.

- Provide staff development to enhance understanding of faculty's responsibility to provide accommodations to students and how to provide accommodations and modifications.

- Provide administration and staff training to enhance institutional understanding of the rights of students with disabilities.

- Participate in administrative and staff training to delineate responsibilities relative to students with disabilities.

- Training for staff (e.g., residential life, maintenance, and library personnel) to facilitate and enhance the integration of students with disabilities into the college community.

\subsection{Provide information to faculty about services available to students with} disabilities. 
- Provide staff development for faculty and staff to refer students who may need disability services. 


\section{Academic Adjustments}

To facilitate equal access to postsecondary education for students with disabilities, the office that provides services to students with disabilities should:

\subsection{Maintain records that document the student's plan for the provision of selected accommodations.}

- Create a confidential file on each student including relevant information pertaining to eligibility and provision of services.

- Document the basis for accommodation decisions and recommendations.

- Develop a case management system that addresses the maintenance of careful and accurate records of each student.

\subsection{Determine with students appropriate academic accommodations and} services.

- Conduct a review of disability documentation.

- Incorporate a process that fosters the use of effective accommodations, taking into consideration the environment, task, and the unique needs of the individual.

- Review the diagnostic testing to determine appropriate accommodations or supports.

- Accommodation requests are handled on a case-by-case basis and relate to students' strengths and weaknesses, which are identified in their documentation.

- Determine if the student's documentation supports the need for the requested accommodation.

- On a case-by-case basis, consider providing time-limited, provisional accommodations pending receipt of clinical documentation, after which a determination is made.

\subsection{Collaborate with faculty to ensure that reasonable academic accommodations do not fundamentally alter the program of study.}

- Provide reasonable accommodations for students with disabilities to ensure program accessibility, yet do not compromise the essential elements of the course or curriculum. 
- Ensure an array of supports, services and assistive technology so that student needs for modifications and accommodations can be met. 
To facilitate equal access to postsecondary education for students with disabilities, the office that provides services to students with disabilities should:

5.1 Use a service delivery model that encourages students with disabilities to develop independence.

- Educate and assist students with disabilities to function independently.

- Develop a program mission that is committed to promoting self-determination for students with disabilities. 


\section{Policies and Procedures}

To facilitate equal access to postsecondary education for students with disabilities, the office that provides services to students with disabilities should:

6.1 Develop, review and revise written policies and guidelines regarding procedures for determining and accessing "reasonable accommodations."

- Develop, review and revise procedures for students to follow regarding the accommodation process.

- Develop, review and revise policies describing disability documentation review.

- Develop, review and revise procedures regarding student eligibility for services.

- Develop, review and revise eligibility for services policies and procedures that delineate steps required for students to access services, including accommodations.

- Develop, review and revise procedures to determine if students receive provisional accommodations during any interim period (e.g., assessment is being updated or re-administered).

\subsection{Assist with the development, review, and revision of written policies and} guidelines for institutional rights and responsibilities with respect to service provision.

- Assist with the development, review, and revision of policies and procedures on course substitutions, including institution requirements (e.g., foreign language or writing requirements).

- Assist with the development, review, and revision of policy and procedures regarding priority registration.

- Develop, review and revise policies and procedures that maintain a balance between "reasonable accommodation" and "otherwise qualified" while "not substantially altering technical standards."

- Develop, review, and revise policies regarding the provision of disability services (e.g., interpreter services).

- Develop, review and revise disability documentation guidelines to determine eligibility for accommodations at the postsecondary level. 
- Assist the institution with the development, review, and revision of policies regarding the faculty's responsibility for serving students with disabilities.

- Collaborate with the development, review, and revision of policies regarding IT (e.g., alternative formats). 


\subsection{Develop, review and revise written policies and guidelines for student}

rights and responsibilities with respect to receiving services.

- Develop consistent practices and standards for documentation.

- Develop, review and revise policies regarding students' responsibility to provide recent and appropriate documentation of disability.

- Assist with the development, review, and revision of policies regarding students' responsibility to meet the Institution's qualifications and essential technical, academic, and institutional standards.

- Develop, review and revise policies regarding students' responsibility to follow specific procedures for obtaining reasonable and appropriate accommodations, academic adjustments, and/or auxiliary aids.

- Assist with the development, review, and revision of procedures a student must follow regarding program modifications (e.g., course substitutions).

- Develop, review, and revise procedures for notifying staff (e.g., interpreter, notetaker) when a student will not attend a class meeting.

\subsection{Develop, review and revise written policies and guidelines regarding confidentiality of disability information.}

- Develop, review and revise policy articulating students understanding of who will have access to their documentation and the assurance that it will not be shared inappropriately with other campus units.

- Develop, review and revise policies and procedures regarding privacy of records, including testing information, prior records and permission to release confidential records to other agencies or individuals.

\subsection{Assist with the development, review, and revision of policies and} guidelines for settling a formal complaint regarding the determination of a "reasonable accommodation."

- Assist with the development, review, and revision of procedures for resolving disagreements regarding specific accommodation requests, including a defined process by which a review of the request can occur.

- Assist with the development, review, and revision of compliance efforts and procedures to investigate complaints.

- Assist with the development, review, and revision of a conflict resolution process with a systematic procedure to follow by both the grievant and the institutional representative. 


\section{Program Administration and Evaluation}

To facilitate equal access to postsecondary education for students with disabilities, the office that provides services to students with disabilities should:

7.1 Provide services that are aligned with the institution's mission or services philosophy.

- Develop a program mission statement and philosophy that is compatible with the mission of the institution.

- Program personnel and other institutional staff understand and support the mission of the office for students with disabilities.

7.2 Coordinate services for students with disabilities through a full-time professional.

- At least one full-time professional is responsible for disability services as a primary role.

7.3 Collect student feedback to measure satisfaction with disability services.

- Assess the effectiveness of accommodations and access provided to students with disabilities (e.g., timeliness of response to accommodation request).

- Student satisfaction data is included in evaluation of disability services.

7.4 Collect data to monitor use of disability services.

- Provide feedback to physical plant regarding physical access for students with disabilities.

- Collect data to assess the effectiveness of services provided.

- Collect data to identify ways the program can be improved.

- Collect data to project program growth and needed funding increases.

\subsection{Report program evaluation data to administrators.}

- Develop an annual evaluation report on your program using the qualitative and quantitative data you've collected.

\subsection{Provide fiscal management of the office that serves students with} disabilities. 
- Develop a program budget.

- Effectively manage your program's fiscal resources.

- Seek additional internal or external funds as needed.

- Develop political support for your program and its budget.

\subsection{Collaborate in establishing procedures for purchasing the adaptive} equipment needed to assure equal access.

- Assist with the determination of the needs for assistive technology and adaptive equipment at your institution.

- Advise other departments regarding the procurement of needed assistive technology and adaptive equipment.

- Provide or arrange for assistance to students to operate assistive technology and adaptive equipment. 


\section{Training and Professional Development}

To facilitate equal access to postsecondary education for students with disabilities, the office that provides services to students with disabilities should:

8.1 Provide disability services staff with on-going opportunities for professional development.

- Provide orientation and staff development for new disability personnel.

- Ensure that professional development funds are available for disability personnel.

- Provide opportunities for ongoing training based on a needs assessment of the knowledge and skills of disability personnel.

8.2 Provide services by personnel with training and experience working with college students with disabilities (e.g., student development, degree programs).

- Ensure staff can understand and interpret assessments/documentation.

8.3 Assure that personnel adhere to relevant Codes of Ethics (e.g., AHEAD, $A P A)$.

- Refer to and apply a relevant professional code of ethics when dealing with challenging situations. 


\section{Appendix C: Online Survey}

Q1. Thank you for taking the time to complete this survey. This survey is part of a dissertation research project conducted by Heather Wizikowski in the School of Educational Studies, Claremont Graduate University, with permission from your university. It is designed to study the college academic experiences of students with learning, physical, or cognitive disabilities. Your responses are key to personalizing the discussion on academic support for this group of students. You will be asked questions regarding who you are as a student, selfidentification practices, self-advocacy skills, accommodations, and your academic experiences in college. The survey should take approximately 15-20 minutes to complete. If you are unable to complete the survey in one block of time, you may save your responses and come back to the survey anytime before the survey closing at 12:01am on Wednesday, May 16, 2012.

The results of this survey will be used only for academic discussion purposes and to make general recommendations to colleges on ways they can better support the unique needs of students with disabilities. All survey responses are confidential. Your individual privacy will be maintained in all publications or presentations resulting from this study. In order to preserve the confidentiality of your responses, your survey will be recorded using an assigned participant number, not by any identifiable feature. Your name will not be requested, nor recorded, in any manner.

If you qualify to participate in the survey, you may record your email address at the completion of the survey to enter the drawing for one of the ten $\$ 50$ Amazon gift cards. If you choose to enter the drawing, your email address will not be connected to your survey responses.

No risks are anticipated from taking part in this study. If you feel uncomfortable with the survey questions, you can withdraw from the study. If you decide to quit at any time before you have finished the questionnaire, your answers will not be recorded.

By beginning the survey, you acknowledge that you are over the age of 18, have a disability, and you understand the above information and agree to participate in this research, with the knowledge that you are free to withdraw your participation by exiting out of the survey at any time without penalty. 
Q2 How old were you when you were first diagnosed with a disability?

O Birth

O 1

○ 2

O 3

○ 4

O 5

O 6

○ 7

○ 8

○ 9

O 10

O 11

○ 12

○ 13

O 14

○ 15

O 16

O 17

○ 18

O 19

O 20

O 21

O 22

O 23

O 24

O 25

O 26

O 27

O 29

O 29

O 30

O 31 or older

Q3 Which of these disability categories best describes that first diagnosis?

O Autism

Deaf-Blindness

O Deafness

O Developmental Delay

O Emotional Disturbance

O Hearing Impairment

O Intellectual Disability

O Multiple Disabilities

O Orthopedic Impairment

O Other Health Impairment (ADD/ADHD, health issues, etc.)

O Specific Learning Disability

O Speech or Language Disorder

O Traumatic brain injury

O Visual Impairment 
Q4 Which of these disability categories best describes your current diagnosis?

O Autism

O Deaf-Blindness

O Deafness

O Emotional Disturbance

O Hearing Impairment

O Intellectual Disability

O Multiple Disabilities

O Orthopedic Impairment

O Other Health Impairment (ADD/ADHD, health issues, etc.)

O Specific Learning Disability

O Speech or Language Disorder

O Traumatic brain injury

O Visual Impairment

Q5 Are you:

O Female

O Male

Q2. This next set of questions will ask you about your college experiences sharing with others about your disability. For the purposes of this survey, self-identification is defined as sharing your learning strengths and weaknesses pertaining to your disability with another person, either in a conversational (speaking with friends or faculty) or formal manner (i.e. documentation, such as results of psycho-educational assessments or formal accommodation requests).

Q7 Have you self-identified to:

\begin{tabular}{|c|c|c|}
\hline Academic Support Services & Yes & No \\
College faculty members & $\square$ & $\square$ \\
Academic Advisor & $\square$ & $\square$ \\
Other students & $\square$ & $\square$ \\
Other support staff (Residence Hall & $\square$ & $\square$ \\
Staff, Career Services, Health & & $\square$ \\
Services, etc.) & $\square$ & \\
\hline
\end{tabular}

Q8 When did you self-identify your learning needs at this college?

O When I applied

O When I registered/enrolled

$O$ When I began struggling in a class

O When I received a poor final grade in a class

O When I had trouble with a non-academic issue (health services, housing, etc.)

O When I had difficulty with a particular faculty member

Q9 I self-identified:

O My first semester

O My second semester

O My second year

O My third year

My fourth year

My fifth year or later 
Q10. This next set of questions will ask about how you self-advocate in your academic life. Self-advocacy is defined as: the ability to recognize and meet the needs specific to one's disability or attention disorder.

Independent decision-making and the ability to express one's needs are two critical elements of self-advocacy.

Q11 Please rate the following statements:

\begin{tabular}{|c|c|c|c|c|}
\hline & $\begin{array}{l}\text { (1) Strongly } \\
\text { Disagree }\end{array}$ & (2) & (3) & (4) Strongly Agree \\
\hline $\begin{array}{l}\text { I am aware of the } \\
\text { self-advocacy skills } \\
\text { needed to be } \\
\text { successful in } \\
\text { college. }\end{array}$ & $\square$ & $\square$ & $\square$ & $\square$ \\
\hline $\begin{array}{l}\text { I am confident } \\
\text { using self-advocacy } \\
\text { skills in college. }\end{array}$ & $\square$ & $\square$ & $\square$ & $\square$ \\
\hline
\end{tabular}

Q12 Do you feel comfortable making decisions without consulting with anyone else regarding your learning needs?

O Yes

O No

Q13 I consult with the following people regarding my learning needs:

\begin{tabular}{|c|c|c|c|c|}
\hline & $\begin{array}{l}\text { (1) Strongly } \\
\text { Disagree }\end{array}$ & (2) & (3) & (4) Strongly Agree \\
\hline $\begin{array}{l}\text { Academic Support } \\
\text { Services }\end{array}$ & $\square$ & $\square$ & $\square$ & $\square$ \\
\hline Parents & $\square$ & $\square$ & $\square$ & $\square$ \\
\hline Friends & $\square$ & $\square$ & $\square$ & $\square$ \\
\hline Academic Advisor & $\square$ & $\square$ & $\square$ & $\square$ \\
\hline $\begin{array}{l}\text { Personal } \\
\text { Therapist/Counselor }\end{array}$ & $\square$ & $\square$ & $\square$ & $\square$ \\
\hline $\begin{array}{l}\text { I consult with } \\
\text { someone other than } \\
\text { the above }\end{array}$ & $\square$ & $\square$ & $\square$ & $\square$ \\
\hline
\end{tabular}

Q14 If you selected "I consult with someone other than the above" please list them here: 
Q15 Please rate the following:

\begin{tabular}{|c|c|c|c|c|}
\hline & $\begin{array}{l}\text { (1) Strongly } \\
\text { Disagree }\end{array}$ & (2) & (3) & (4) Strongly Agree \\
\hline $\begin{array}{l}\text { The ability to } \\
\text { describe my } \\
\text { learning needs } \\
\text { makes me a } \\
\text { successful student. }\end{array}$ & $\square$ & $\square$ & $\square$ & $\square$ \\
\hline $\begin{array}{l}\text { Following a daily } \\
\text { routine makes me a } \\
\text { successful student. }\end{array}$ & $\square$ & $\square$ & $\square$ & $\square$ \\
\hline $\begin{array}{l}\text { Having clear goals } \\
\text { makes me a } \\
\text { successful student. }\end{array}$ & $\square$ & $\square$ & $\square$ & $\square$ \\
\hline $\begin{array}{l}\text { Knowing stress } \\
\text { management } \\
\text { techniques makes } \\
\text { me a successful } \\
\text { student. }\end{array}$ & $\square$ & $\square$ & $\square$ & $\square$ \\
\hline $\begin{array}{l}\text { Participating in non- } \\
\text { academic on- } \\
\text { campus activities } \\
\text { makes me a } \\
\text { successful student. }\end{array}$ & $\square$ & $\square$ & $\square$ & $\square$ \\
\hline $\begin{array}{l}\text { Seeking help when I } \\
\text { have personal } \\
\text { difficulties makes } \\
\text { me a successful } \\
\text { student. }\end{array}$ & $\square$ & $\square$ & $\square$ & $\square$ \\
\hline $\begin{array}{l}\text { Making my own } \\
\text { academic decisions } \\
\text { makes me a } \\
\text { successful student. }\end{array}$ & $\square$ & $\square$ & $\square$ & $\square$ \\
\hline $\begin{array}{l}\text { Having a balanced } \\
\text { life (school, social, } \\
\text { family, work) makes } \\
\text { me a successful } \\
\text { student. }\end{array}$ & $\square$ & $\square$ & $\square$ & $\square$ \\
\hline $\begin{array}{l}\text { Having interests } \\
\text { outside of this } \\
\text { college makes me a } \\
\text { successful student. }\end{array}$ & $\square$ & $\square$ & $\square$ & $\square$ \\
\hline $\begin{array}{l}\text { Reading about } \\
\text { successful college } \\
\text { students with } \\
\text { disabilities or } \\
\text { attention disorders } \\
\text { makes me a } \\
\text { successful student. }\end{array}$ & $\square$ & $\square$ & $\square$ & $\square$ \\
\hline $\begin{array}{l}\text { Being able to } \\
\text { describe my }\end{array}$ & $\square$ & $\square$ & $\square$ & $\square$ \\
\hline
\end{tabular}




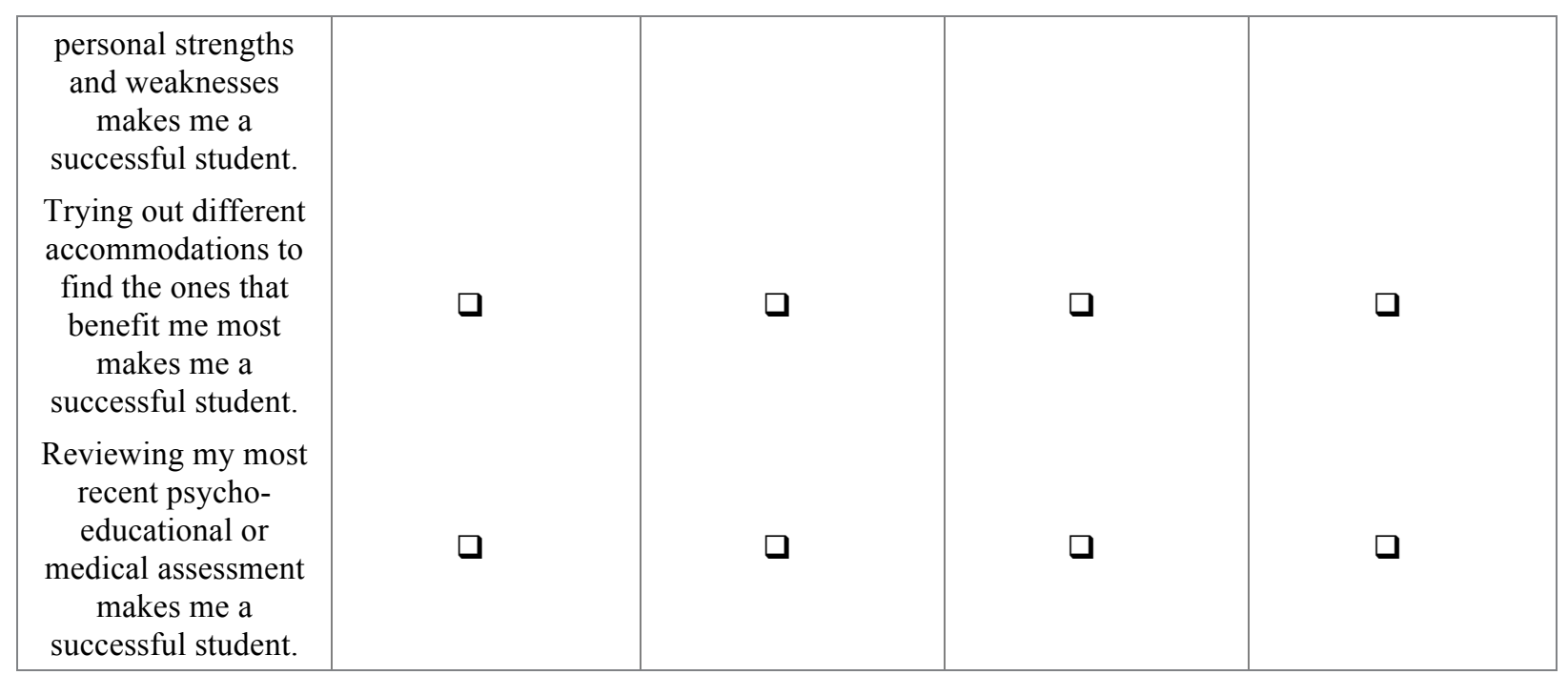

Q16 Please rate the following statements: 


\begin{tabular}{|c|c|c|c|c|}
\hline & $\begin{array}{l}\text { (1) Strongly } \\
\text { Disagree }\end{array}$ & $(2)$ & (3) & (4) Strongly Agree \\
\hline $\begin{array}{l}\text { I feel confident } \\
\text { speaking with } \\
\text { faculty members } \\
\text { regarding my } \\
\text { specific learning } \\
\text { needs. }\end{array}$ & $\square$ & $\square$ & $\square$ & $\square$ \\
\hline $\begin{array}{l}\text { I feel confident } \\
\text { speaking with other } \\
\text { students either in- } \\
\text { class or outside of } \\
\text { class about my } \\
\text { specific learning } \\
\text { needs. }\end{array}$ & $\square$ & $\square$ & $\square$ & $\square$ \\
\hline $\begin{array}{l}\text { I feel confident } \\
\text { speaking with } \\
\text { friends about my } \\
\text { specific learning } \\
\text { needs. }\end{array}$ & $\square$ & $\square$ & $\square$ & $\square$ \\
\hline $\begin{array}{l}\text { I feel in control of } \\
\text { decisions regarding } \\
\text { my accommodation } \\
\text { needs. }\end{array}$ & $\square$ & $\square$ & $\square$ & $\square$ \\
\hline $\begin{array}{l}\text { I feel I have a strong } \\
\text { understanding of my } \\
\text { legal rights as a } \\
\text { student with a } \\
\text { disability or } \\
\text { attention disorder. }\end{array}$ & $\square$ & $\square$ & $\square$ & $\square$ \\
\hline $\begin{array}{l}\text { I think I would } \\
\text { benefit from self- } \\
\text { advocacy skills } \\
\text { training. }\end{array}$ & $\square$ & $\square$ & $\square$ & $\square$ \\
\hline
\end{tabular}

Q17 Has a faculty member at this college ever refused to provide you accommodations?

O Yes

O No

Q18 What did you do when you were refused accommodations? 
Q19 Please rate the following:

\begin{tabular}{|c|c|c|c|c|}
\hline & $\begin{array}{c}\text { (1) Strongly } \\
\text { Disagree }\end{array}$ & (2) & (3) & (4) Strongly Agree \\
\hline $\begin{array}{l}\text { The American with } \\
\text { Disabilities Act } \\
\text { (ADA) protects my } \\
\text { rights as a college } \\
\text { student with a } \\
\text { disability. }\end{array}$ & $\square$ & $\square$ & $\square$ & $\square$ \\
\hline $\begin{array}{l}\text { The Individuals } \\
\text { with Disabilities } \\
\text { Education Act } \\
\text { (IDEA) } 2004 \\
\text { protects my rights } \\
\text { as a college student } \\
\text { with a disability. }\end{array}$ & $\square$ & $\square$ & $\square$ & $\square$ \\
\hline
\end{tabular}

Q20. The next set of questions asks about academic support services both at this college and in general. Academic support services ensure equal access for college students with disabilities. These offices approve and coordinate accommodations and services for students with disabilities to help them acquire skills essential to achieve academic and personal success. These offices can have many different names such as: Academic Support Services, Disability Services, or Office of Disabled Student Services.

Q21 Have you received any support services since registering with the college's academic support services? $\mathrm{O}$ Yes

O No

Q22 Do you receive services (for the current semester/quarter) from the college's academic support services?

O Yes

O No

Q23 For each of the following general accommodations provided by typical academic support offices listed below, please indicate (1) if you have used it and (2) how useful it was for you: 


\begin{tabular}{|c|c|c|c|c|c|}
\hline & Have Used & \multicolumn{4}{|c|}{ Usefulness } \\
\hline & Yes & $\begin{array}{l}\text { (1) Not at all } \\
\text { useful }\end{array}$ & (2) & (3) & (4) Very useful \\
\hline Note taker & $\mathrm{O}$ & $\mathrm{O}$ & $\mathrm{O}$ & $\mathrm{O}$ & 0 \\
\hline Proofreader & O & $\mathrm{O}$ & O & $\mathrm{O}$ & O \\
\hline $\begin{array}{c}\text { Alternative } \\
\text { exam format } \\
\text { (extended time, } \\
\text { alternate } \\
\text { location, oral vs. } \\
\text { written, etc.) }\end{array}$ & $\mathrm{O}$ & $\mathrm{O}$ & $\mathrm{O}$ & $\mathrm{O}$ & O \\
\hline $\begin{array}{l}\text { Substitute } \\
\text { coursework } \\
\text { required for } \\
\text { graduation }\end{array}$ & $\mathrm{O}$ & $\mathrm{O}$ & $\mathrm{O}$ & $\mathrm{O}$ & $\mathrm{O}$ \\
\hline $\begin{array}{l}\text { Reader } \\
\text { services(audio } \\
\text { or person) }\end{array}$ & O & $\mathrm{O}$ & $\mathrm{O}$ & $\mathrm{O}$ & $\mathrm{O}$ \\
\hline Transcription & $\mathrm{O}$ & 0 & $\mathrm{O}$ & 0 & 0 \\
\hline $\begin{array}{l}\text { Registration, } \\
\text { financial aid } \\
\text { assistance }\end{array}$ & $\mathrm{O}$ & $\mathrm{O}$ & $\mathrm{O}$ & $\mathrm{O}$ & $\mathrm{O}$ \\
\hline $\begin{array}{c}\text { Specialized } \\
\text { software } \\
\text { supplied by this } \\
\text { college } \\
\text { (Kurzweil, etc.) }\end{array}$ & $\mathrm{O}$ & $\mathrm{O}$ & 0 & $\mathrm{O}$ & $\mathrm{O}$ \\
\hline $\begin{array}{l}\text { University- } \\
\text { based }\end{array}$ & & & & & \\
\hline $\begin{array}{l}\text { Counseling or } \\
\text { Psychological } \\
\text { Services }\end{array}$ & O & 0 & $\mathrm{O}$ & $\mathrm{O}$ & $\mathrm{O}$ \\
\hline Peer Tutoring & $\mathrm{O}$ & O & O & O & O \\
\hline Writing Center & $\mathrm{O}$ & O & 0 & O & O \\
\hline $\begin{array}{l}\text { Voice recorder } \\
\text { used in class }\end{array}$ & 0 & 0 & 0 & O & O \\
\hline $\begin{array}{l}\text { Sign language } \\
\text { interpretation }\end{array}$ & O & 0 & 0 & $\mathrm{O}$ & 0 \\
\hline $\begin{array}{l}\text { Captioning } \\
\text { services }\end{array}$ & 0 & 0 & 0 & $\mathrm{O}$ & 0 \\
\hline $\begin{array}{c}\text { Alternative } \\
\text { seating in class }\end{array}$ & $\mathrm{O}$ & O & O & $\mathrm{O}$ & $\mathrm{O}$ \\
\hline $\begin{array}{l}\text { Texts in } \\
\text { alternative } \\
\text { formats }\end{array}$ & $\mathrm{O}$ & 0 & $\mathrm{O}$ & 0 & 0 \\
\hline $\begin{array}{l}\text { Diagnostic } \\
\text { assessment }\end{array}$ & 0 & O & O & O & 0 \\
\hline Advising & 0 & 0 & 0 & 0 & 0 \\
\hline
\end{tabular}




\begin{tabular}{|c|c|c|c|c|c|}
\hline services & & & & & \\
\hline $\begin{array}{l}\text { Adaptive } \\
\text { equipment }\end{array}$ & 0 & 0 & 0 & 0 & 0 \\
\hline $\begin{array}{c}\text { Referrals to } \\
\text { outside agencies }\end{array}$ & $\mathrm{O}$ & 0 & 0 & 0 & O \\
\hline $\begin{array}{c}\text { Parking } \\
\text { arrangements }\end{array}$ & 0 & 0 & 0 & 0 & O \\
\hline $\begin{array}{l}\text { Computer lab } \\
\text { specialized } \\
\text { access }\end{array}$ & 0 & 0 & 0 & 0 & O \\
\hline $\begin{array}{l}\text { Consultation } \\
\text { with faculty on } \\
\text { your behalf }\end{array}$ & $\mathrm{O}$ & 0 & 0 & O & O \\
\hline $\begin{array}{l}\text { Documentation } \\
\text { sent to } \\
\text { professor(s) on } \\
\text { your behalf }\end{array}$ & 0 & 0 & 0 & O & 0 \\
\hline
\end{tabular}

Q24 Please indicate the extent to which you agree or disagree with the following statements:

\begin{tabular}{|c|c|c|c|c|}
\hline & $\begin{array}{l}\text { (1) Strongly } \\
\text { Disagree }\end{array}$ & (2) & (3) & (4) Strongly Agree \\
\hline $\begin{array}{l}\text { Accommodations } \\
\text { should the } \\
\text { responsibility of this } \\
\text { college to } \\
\text { coordinate. }\end{array}$ & $\square$ & $\square$ & $\square$ & $\square$ \\
\hline $\begin{array}{l}\text { Accommodations } \\
\text { should be my } \\
\text { responsibility to } \\
\text { coordinate. }\end{array}$ & $\square$ & a & a & $\square$ \\
\hline $\begin{array}{l}\text { I am clear on the } \\
\text { documentation } \\
\text { requirements to } \\
\text { receive } \\
\text { accommodations at } \\
\text { this college. }\end{array}$ & $\square$ & $\square$ & 口 & $\square$ \\
\hline $\begin{array}{l}\text { I am clear on the } \\
\text { process to receive } \\
\text { academic support } \\
\text { services at this } \\
\text { college. }\end{array}$ & $\square$ & $\square$ & $\square$ & $\square$ \\
\hline $\begin{array}{l}\text { I feel supported by } \\
\text { the academic } \\
\text { support office at this } \\
\text { college. }\end{array}$ & $\square$ & $\square$ & $\square$ & $\square$ \\
\hline
\end{tabular}

Q25 On average, how many times do you contact the academic support offices per semester? Please move slider to select a number between $0-50$.

How many times per semester? 
Q26 Please rate the following based on your experience with your academic support office:

\begin{tabular}{|c|c|c|c|c|}
\hline & $\begin{array}{l}\text { (1) Very } \\
\text { Unsatisfied }\end{array}$ & (2) & (3) & (4) Very Satisfied \\
\hline $\begin{array}{l}\text { Communication } \\
\text { with me }\end{array}$ & $\square$ & $\square$ & $\square$ & $\square$ \\
\hline $\begin{array}{l}\text { Communication } \\
\text { with faculty on my } \\
\text { behalf }\end{array}$ & $\square$ & $\square$ & $\square$ & $\square$ \\
\hline $\begin{array}{l}\text { Documentation } \\
\text { process }\end{array}$ & $\square$ & $\square$ & $\square$ & $\square$ \\
\hline $\begin{array}{l}\text { Documentation } \\
\text { requirements }\end{array}$ & $\square$ & $\square$ & $\square$ & $\square$ \\
\hline $\begin{array}{l}\text { Efficiency of } \\
\text { support office }\end{array}$ & $\square$ & $\square$ & $\square$ & $\square$ \\
\hline $\begin{array}{l}\text { Approachability of } \\
\text { staff }\end{array}$ & $\square$ & $\square$ & $\square$ & $\square$ \\
\hline Helpfulness of staff & $\square$ & $\square$ & $\square$ & $\square$ \\
\hline $\begin{array}{l}\text { Respect towards } \\
\text { students }\end{array}$ & $\square$ & $\square$ & $\square$ & $\square$ \\
\hline $\begin{array}{l}\text { Knowledge level of } \\
\text { staff regarding } \\
\text { disabilities }\end{array}$ & $\square$ & $\square$ & $\square$ & $\square$ \\
\hline $\begin{array}{l}\text { Knowledge level of } \\
\text { staff regarding } \\
\text { academic programs } \\
\text { at this school }\end{array}$ & $\square$ & $\square$ & $\square$ & $\square$ \\
\hline $\begin{array}{l}\text { Knowledge level of } \\
\text { staff regarding } \\
\text { accommodations }\end{array}$ & $\square$ & $\square$ & $\square$ & $\square$ \\
\hline $\begin{array}{l}\text { Knowledge level of } \\
\text { staff regarding } \\
\text { support other than } \\
\text { classroom } \\
\text { accommodations } \\
\text { (career advisement, } \\
\text { outside resources, } \\
\text { etc.) }\end{array}$ & $\square$ & $\square$ & $\square$ & $\square$ \\
\hline $\begin{array}{l}\text { Availability of } \\
\text { education } \\
\text { opportunities for } \\
\text { students } \\
\text { (workshops, } \\
\text { lectures, etc) on } \\
\text { disability issues }\end{array}$ & $\square$ & $\square$ & $\square$ & $\square$ \\
\hline
\end{tabular}


Q27 Please select (1) if the service is currently offered and (2) if you would like the service offered by your Academic Support Office:

\begin{tabular}{|c|c|c|}
\hline & Currently Offered & Should Offer \\
\hline & Yes & Yes \\
\hline Mentoring & O & $\mathrm{O}$ \\
\hline $\begin{array}{l}\text { Mentoring with an older student } \\
\text { with a similar disability }\end{array}$ & $\mathrm{O}$ & $\mathrm{O}$ \\
\hline Tutoring with disability specialists & $\mathrm{O}$ & $\mathrm{O}$ \\
\hline $\begin{array}{l}\text { Community building (support } \\
\text { groups, study groups) }\end{array}$ & $\mathrm{O}$ & $\mathrm{O}$ \\
\hline $\begin{array}{l}\text { Disability presentation at freshmen } \\
\text { orientation for all students }\end{array}$ & $\mathrm{O}$ & $\mathrm{O}$ \\
\hline $\begin{array}{l}\text { Social media connections } \\
\text { (Facebook group, etc.) }\end{array}$ & O & $\mathrm{O}$ \\
\hline Self-Advocacy skills training & O & $\mathrm{O}$ \\
\hline Other & O & O \\
\hline
\end{tabular}

Q28 What other services would you like to see offered?

Q29. This last set of questions asks for further information about you as a student. This demographic information will aid in determining how colleges can better meet the needs of students with disabilities.

Q30 Please answer the following:

\begin{tabular}{|c|c|c|c|}
\hline & Yes & No & Not Applicable \\
\hline $\begin{array}{c}\text { Do you have a current } \\
\text { psycho-educational } \\
\text { evaluation (official testing } \\
\text { and documentation from } \\
\text { an educational } \\
\text { psychologist or medical } \\
\text { doctor pertaining to your } \\
\text { disability? }\end{array}$ & $\square$ & $\square$ & $\square$ \\
\hline $\begin{array}{l}\text { Have you ever left school } \\
\text { for an extended period of } \\
\text { time due to your } \\
\text { disability? (At least one } \\
\text { semester) }\end{array}$ & $\square$ & $\square$ & $\square$ \\
\hline $\begin{array}{c}\text { Did you have an } \\
\text { Individualized Education } \\
\text { Plan (IEP) in high school? }\end{array}$ & $\square$ & $\square$ & $\square$ \\
\hline $\begin{array}{c}\text { Did you have an } \\
\text { Individualized Education } \\
\text { Plan (IEP) in elementary } \\
\text { school? }\end{array}$ & $\square$ & 口 & 口 \\
\hline $\begin{array}{l}\text { Did you have a Section } \\
504 \text { Plan in high school? }\end{array}$ & $\square$ & $\square$ & $\square$ \\
\hline $\begin{array}{c}\text { Did you have a Section } \\
504 \text { Plan in elementary } \\
\text { school? }\end{array}$ & $\square$ & $\square$ & $\square$ \\
\hline
\end{tabular}


Q31 I attended:

O Public high school

O Private high school

O Homeschool

O Charter School

O Other

Q32 If you selected "other" please list below:

Q33 Please rate the following:

\begin{tabular}{|c|c|c|c|c|}
\hline & $\begin{array}{l}\text { (1) Strongly } \\
\text { Disagree }\end{array}$ & (2) & (3) & (4) Strongly Agree \\
\hline $\begin{array}{l}\text { In high school, I had } \\
\text { a special education } \\
\text { transition plan } \\
\text { specifically related } \\
\text { to attending a four- } \\
\text { year college. }\end{array}$ & 口 & $\square$ & $\square$ & $\square$ \\
\hline $\begin{array}{l}\text { I feel that my high } \\
\text { school prepared me } \\
\text { with appropriate } \\
\text { information about } \\
\text { transitioning to } \\
\text { college with my } \\
\text { learning needs. }\end{array}$ & $\square$ & $\square$ & $\square$ & $\square$ \\
\hline $\begin{array}{l}\text { My academic } \\
\text { support office at this } \\
\text { college explained } \\
\text { the differences } \\
\text { between high school } \\
\text { and college supports } \\
\text { and disability laws. }\end{array}$ & $\square$ & $\square$ & $\square$ & $\square$ \\
\hline $\begin{array}{l}\text { My high school } \\
\text { explained the } \\
\text { differences between } \\
\text { high school and } \\
\text { college supports and } \\
\text { disability laws. }\end{array}$ & $\square$ & $\square$ & $\square$ & $\square$ \\
\hline $\begin{array}{l}\text { I received advocacy } \\
\text { skills training } \\
\text { (formal or informal) } \\
\text { in high school. }\end{array}$ & $\square$ & $\square$ & $\square$ & $\square$ \\
\hline $\begin{array}{l}\text { I have received } \\
\text { advocacy skills } \\
\text { training in college. }\end{array}$ & $\square$ & $\square$ & $\square$ & $\square$ \\
\hline
\end{tabular}


Q34 Do you attend:

O Public University

O Private University

Q35 How many four-year schools did you apply to including this school?
O 1
O 2
○ 3
○ 4
○ 5
○ 6
○ 7
○ 8
○ 9
O 10 or more

Q36 I selected this college because:

\begin{tabular}{|c|c|c|}
\hline The only school I applied to & Yes & No \\
Close to home & $\square$ & $\square$ \\
Far from home & $\square$ & $\square$ \\
The campus & $\square$ & $\square$ \\
Particular & $\square$ & $\square$ \\
department/major/program & $\square$ & $\square$ \\
Particular faculty member & $\square$ & $\square$ \\
The academic support office would & $\square$ & $\square$ \\
meet my needs & $\square$ & $\square$ \\
Reputation & $\square$ & $\square$ \\
Legacy (parent(s), family attended) & $\square$ & $\square$ \\
Knew I'd be supported well with & $\square$ & $\square$ \\
my learning needs campus-wide & $\square$ & $\square$ \\
The only school I was accepted to & $\square$ & $\square$ \\
Admissions-related requirements & $\square$ & $\square$ \\
Cost & $\square$ & $\square$ \\
Financial aid opportunities & $\square$ & $\square$ \\
Athletics & $\square$ & $\square$ \\
Social activities & & $\square$ \\
\hline
\end{tabular}


Q37 Do you include the following in your academic support system?

\begin{tabular}{|c|c|c|c|c|}
\hline & $\begin{array}{c}\text { (1) Strongly } \\
\text { Disagree }\end{array}$ & $(2)$ & $(3)$ & (4) Strongly Agree \\
\hline Friends & $\square$ & $\square$ & $\square$ & $\square$ \\
Family & $\square$ & $\square$ & $\square$ & $\square$ \\
Academic Support & $\square$ & $\square$ & $\square$ & $\square$ \\
Services & $\square$ & $\square$ & $\square$ & $\square$ \\
Faculty & $\square$ & $\square$ & $\square$ & $\square$ \\
Faculty advisor & $\square$ & $\square$ & $\square$ & $\square$ \\
Private counselor & $\square$ & $\square$ & $\square$ \\
Someone else not & $\square$ & $\square$ & & $\square$ \\
listed & & & $\square$ & $\square$ \\
\hline
\end{tabular}

Q38 If you selected "someone else not listed", please list them below:

Q39 Please indicate the extent to which you agree or disagree with the following statements:

\begin{tabular}{|c|c|c|c|c|}
\hline $\begin{array}{c}\text { I believe this } \\
\text { college was a good } \\
\text { choice for my } \\
\text { specific learning } \\
\text { needs. }\end{array}$ & $\square$ & (2) & (4) Strongly Agree \\
$\begin{array}{c}\text { I will be able to } \\
\text { meet my goal of } \\
\text { graduating from } \\
\text { college. }\end{array}$ & $\square$ & $\square$ & $\square$ & $\square$ \\
\hline
\end{tabular}

Q40 What year are you in school?
O First year
Second year
O Third year
F Fourth year
O Fifth year
Sixth year or more 
Q41 What year did you begin attending this college?

O 2012

○ 2011

O 2010

O 2009

O 2008

O 2007

○ 2006

○ 2005

○ 2004

○ 2003

○ 2002

○ 2001

O 2000

○ 1999

○ 1998

O 1997

O 1996

O 1995

○ 1994

○ 1993

○ 1992

Q42 What semester of the above year did you begin attending this college?

O Fall

O Spring

O Summer

Q43 How many 2-year colleges did you attend prior to enrolling at this university?
O 0
○ 1
O 2
O 3
○ 4
O 5
O 6 or more

Q44 How many 4-year colleges did you attend prior to enrolling at this university?
O 0
O 1
O 2
○ 3
○ 4
O 5
O 6 or more

Q45 Why did you leave your previous four-year college? 
Q46 What year do you anticipate graduating from this college?
O 2012
O 2013
O 2014
O 2015
O 2016
O 2017
O 2018
O 2019
O 2020
O 2021
○ 2022
O 2023
O 2024
O 2025

Q47 What is your current major?

O Accounting

American Studies

O Anthropology

O Art

O Art History

O Athletic Training

O Biochemistry

O Biological Sciences

O Business Administration

O Chemistry

O Child and Adolescent Development

O Civil Engineering

O Communication Studies

O Comparative Literature

O Computer Engineering

O Computer Information Sciences

O Computer Sciences

O Creative Writing

O Creative Producing

O Criminal Justice

O Dance

O Education

O Economics

O Electrical Engineering

O English

O Digital Arts

Environmental Science \& Policy

O Ethnic Studies

O European Studies

O Film Production

O Film Studies

O French 


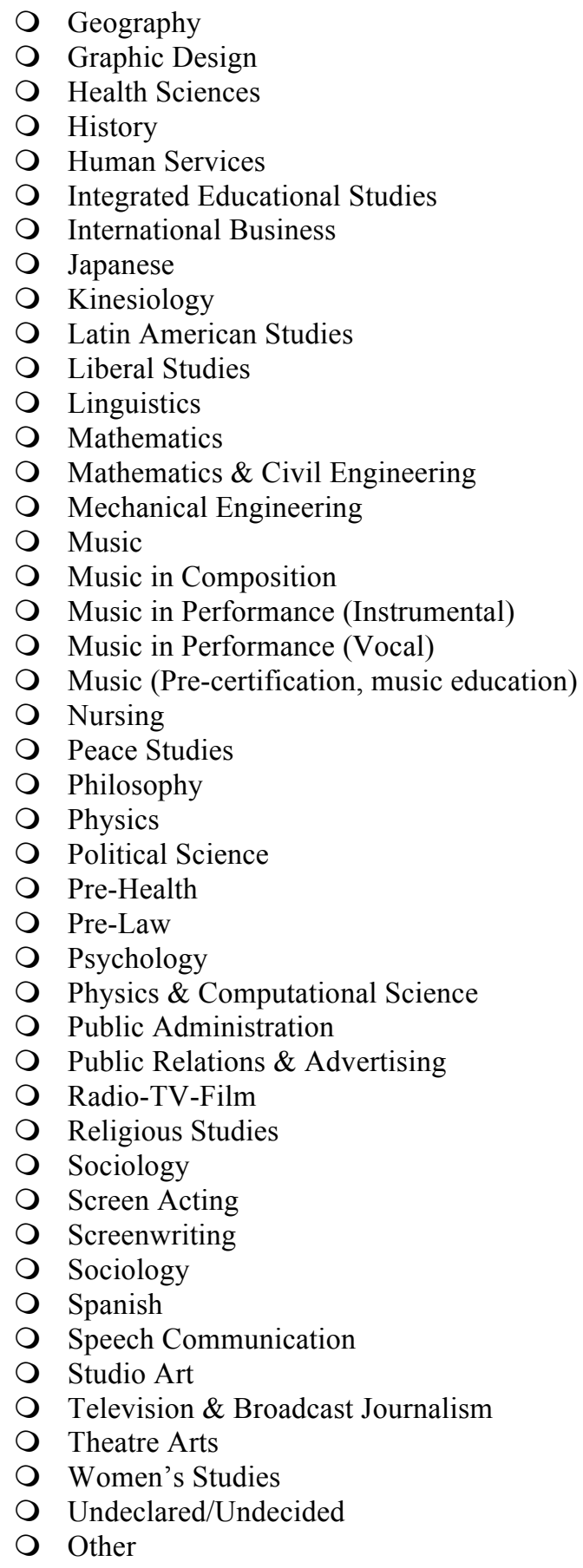




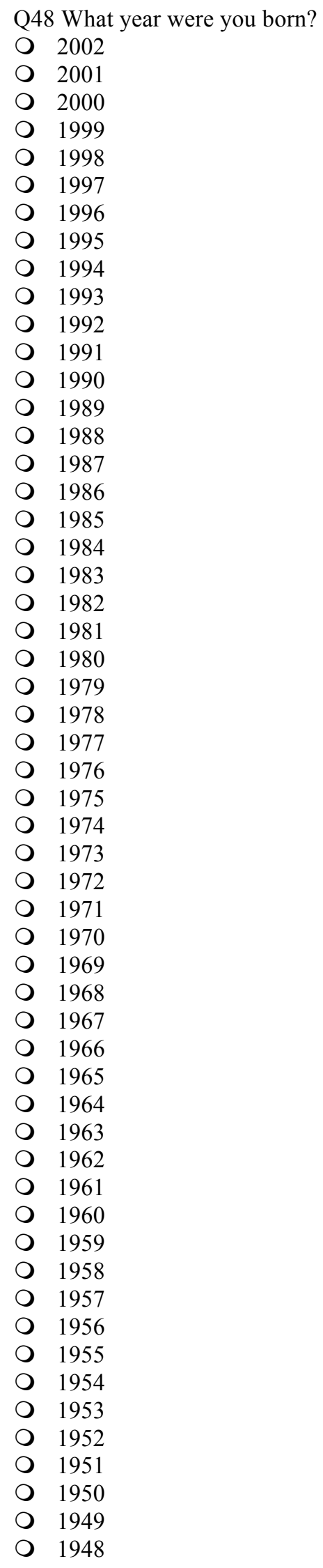

Q48 What year were you born?

○ 2002

○ 2001

○ 2000

○ 1999

○ 1998

○ 1997

○ 1996

○ 1995

○ 1994

○ 1993

○ 1992

- 1991

○ 1990

○ 1989

○ 1988

○ 1987

○ 1986

. 1985

○ 1983

○ 1982

○ 1981

○ 1980

- 1979

- 1978

○ 1976

○ 1975

○ 1974

○ 1973

1972

○ 1970

○ 1969

○ 1968

○ 1964

○ 1963

○ 1962

○ 1961

○ 1960

○ 1958

○ 1957

○ 1956

○ 1955

○ 1954

- 1953

○ 1951

○ 1950

○ 1948 
$\begin{array}{ll}\text { O } & 1947 \\ \text { O } & 1946 \\ \text { O } & 1945 \\ \text { O } & 1944 \\ \text { O } & 1943 \\ \text { O } & 1942 \\ \text { O } & 1941 \\ \text { O } & 1940 \\ \text { O } & 1939 \\ \text { O } & 1938 \\ \text { O } & 1937 \\ \text { O } & 1936 \\ \text { O } & 1935 \\ \text { O } & 1934 \\ \text { O } & 1933 \\ \text { O } & 1932 \\ \text { O } & 1931 \\ \text { O } & 1930\end{array}$

Q49 Do you consider yourself to be Hispanic/Latino(a)?

O Yes

O No

Q50 Please select one of the following categories to describe yourself:

O American Indian or Alaska Native

O Asian

O Black or African American

O Native Hawaiian or other Pacific Islander

O White

I identify with two or more categories

Q51 Is there anything else you would like to add regarding the academic support for students with disabilities at your school?

Q52 If you would like to enter the drawing for one of the ten \$50 Amazon gift cards, please enter your email address here: (By entering your email address, you may also be contacted for voluntary follow-up opportunities.) 
Appendix D: Participant Recruitment Email

Dear [Name of College] Students:

I am a doctoral candidate in Education at Claremont Graduate University and I am conducting a study of college students with disabilities and their knowledge and experiences of academic accommodations, self-advocacy, and self-identification patterns at the college level.

What does this have to do with you? This is a unique opportunity for students with disabilities to have their voices heard in academic literature.

If you have a learning, cognitive, or physical disability or disorder and are over the age of 18 , please consider completing the survey.

The link for the online survey is listed below:

https://trial.qualtrics.com/SE/?SID=SV_1ResMzOeocydvlG

This link will be available from today until Wednesday, May 16, 2012 at 12:01am.

The confidential survey should take approximately 20 minutes to complete. As a way to thank you for your time, you will have the opportunity to enter a drawing for one of ten $\$ 50$ Amazon gift cards at the completion of the survey.

The purpose of this research is to attempt to understand the needs of this growing group of students. Through your participation, I hope to be able to make scholarly recommendations on how to best meet the needs of students with disabilities.

If you have a disability, I hope you will consider taking the survey. Your voluntary participation is very important to furthering research in the rapidly expanding area of successful college students with disabilities.

If you have any questions regarding this survey, please email me directly at heather.wizikowski@cgu.edu.

Questions regarding this study may also be directed to my faculty advisor, Deb Smith, at deb.smith@cgu.edu or Claremont Graduate University Institutional Review Board at irb@cgu.edu.

Thank you,

Heather Wizikowski. M.A.Ed

Doctoral Candidate, School of Educational Studies

Claremont Graduate University 